\title{
Private Tastes and Public Desires: \\ Exploring the perspectives and practices of private collectors who share their collections publicly
}

\author{
By \\ Kiri Griffin \\ BA (Otago University), PGDipArcRec (Victoria University of Wellington)
}

\author{
A thesis \\ submitted in fulfillment \\ of the requirements for the degree of \\ Master of Arts
}

Museum and Heritage Studies Programme

Victoria University of Wellington

2012 


\section{Table of contents}

Table of figures

Acknowledgements viii

Abstract

Introduction 1

Chapter One: Literature review and research design 7

Review of relevant background literature $\quad 7$

The historic relationship between the private collector and the heritage sector $\quad 8$

Established boundaries that distinguish the private collector from heritage institutions $\quad 10$

How values and evaluative judgements regarding collecting blur boundaries $\quad 16$

Studies regarding private collectors and the heritage sector 20

$\begin{array}{ll}\text { Summary } & 22\end{array}$

$\begin{array}{ll}\text { Further relevant theory } & 24\end{array}$

Bourdieu 24

Actor-Network Theory 26

$\begin{array}{ll}\text { Stebbins } & 27\end{array}$

$\begin{array}{ll}\text { Summary } & 27\end{array}$

$\begin{array}{ll}\text { Research design } & 28\end{array}$

Methods 28

Research population $\quad 30$

$\begin{array}{ll}\text { Sampling } & 32\end{array}$

Participants $\quad 33$

Data collection $\quad 35$

Interpretation of empirical material $\quad 37$

$\begin{array}{ll}\text { Archiving } & 37\end{array}$

Credibility 38

Limitations $\quad 38$

Approach to writing up $\quad 39$

$\begin{array}{ll}\text { Summary } & 40\end{array}$

Chapter Two: The social world of the private collector 41

Biographical sketches of participants $\quad 42$

Jim Barr $\quad 42$

Fiona Campbell $\quad 43$

John McCosh $\quad 44$

Peter Smith $\quad 45$

Alison Reid $\quad 46$

Ian Ladds $\quad 47$

Jean Hall $\quad 48$

$\begin{array}{ll}\text { Bruce Lyon } & 49\end{array}$ 
Relationships between private collectors and heritage institutions $\quad 50$

The private collector as audience member $\quad 50$

The private collector as collaborator $\quad 54$

The private collector as amateur? $\quad 56$

$\begin{array}{lr}\text { Values that inform public display } & 59\end{array}$

$\begin{array}{ll}\text { Commitment to objects } & 60\end{array}$

$\begin{array}{ll}\text { Educational context } & 61\end{array}$

Enjoyment of others $\quad 61$

Instigation of others 63

$\begin{array}{ll}\text { Institutional values } & 65\end{array}$

$\begin{array}{ll}\text { Summary } & 66\end{array}$

Chapter Three: The collecting practices of private collectors 68

$\begin{array}{lr}\text { Collection } & 69\end{array}$

Acquisition $\quad 69$

Selection $\quad 73$

Deselection $\quad 76$

$\begin{array}{ll}\text { Research } & 78\end{array}$

$\begin{array}{ll}\text { Cataloguing } & 81\end{array}$

Display

Physical space $\quad 83$

Selection $\quad 86$

$\begin{array}{ll}\text { Interpretation } & 88\end{array}$

$\begin{array}{ll}\text { Visitor feedback } & 92\end{array}$

Conservation 93

Preventative conservation $\quad 93$

$\begin{array}{ll}\text { Restoration } & 98\end{array}$

$\begin{array}{ll}\text { The future of private collectors' collections } & 99\end{array}$

$\begin{array}{lr}\text { Summary } & 103\end{array}$

$\begin{array}{lr}\text { Conclusion } & 106\end{array}$

$\begin{array}{ll}\text { References } & 113\end{array}$

$\begin{array}{lr}\text { Appendix A: Information sheet } & 127\end{array}$

$\begin{array}{ll}\text { Appendix B: Consent form } & 129\end{array}$

Appendix C: Oral history recording agreement form 130

Appendix D: National Oral History Association of New 132

Zealand Code of ethical and technical practice

Appendix E: Interview guide 


\section{Table of figures}

Figure 1. 'Axes of value in objects and collections' (Pearce 1998, 41).

Figure 2. 'Collecting in relation to perceived valuation' (Pearce 1998, 93).

Figure 3. Distinguishing features of contributing participants.

Figure 4. Jim Barr. Frame-grab taken from interview footage captured at Jim Barr's Wellington apartment, 03 October 2011.

Figure 5. Fiona Campbell. Frame-grab taken from interview footage captured at the New Zealand Film Archive Wellington premises, 05 October 2011.

Figure 6. John McCosh. Frame-grab taken from interview footage captured at the Kahutara Taxidermy Gallery, Featherston, 07 October 2011.

Figure 7. Peter Smith. Frame-grab taken from interview footage captured at Peter Smith's Wellington apartment, 14 October 2011.

Figure 8. Alison Reid. Frame-grab taken from interview footage captured at 46 Alison Reid's house, Auckland, 17 October 2011.

Figure 9. Ian Ladds. Frame-grab taken from interview footage captured in Ian 47 Ladds's residential shed, Nelson, 21 October 2011.

Figure 10. Jean Hall. Frame-grab taken from interview footage captured at Lillia’s Lace Museum, Geraldine, 23 October 2011.

Figure 11. Bruce Lyon. Frame-grab taken from interview footage captured 49 at The International Police Museum, Dannevirke, 28 October 2011. 
Figure 12. Wall featuring John McCosh's large heads. Frame-grab taken from

interview footage captured at the Kahutara Taxidermy Gallery, Featherston, 07 October 2011.

Figure 13. The Real Art Roadshow Black and Silver Collection trailers. Image obtained from The Real Art Roadshow "Photo Gallery", with permission of Fiona Campbell.

Figure 14. The Real Art Roadshow Silver Collection truck and trailer. Image obtained from The Real Art Roadshow "Photo Gallery", with permission of Fiona Campbell.

Figure 15. Interior of The Real Art Roadshow Black Collection trailer. Image obtained from The Real Art Roadshow "Photo Gallery", with permission of Fiona Campbell.

Figure 16. Interior of The Real Art Roadshow Silver Collection trailer. Image obtained from The Real Art Roadshow "Photo Gallery", with permission of Fiona Campbell.

Figure 17. Uniforms on display at The International Police Museum. Frame-grab taken from interview footage captured at The International Police Museum, Dannevirke, 28 October 2011.

Figure 18. Carport at The International Police Museum. Frame-grab taken from interview footage captured at The International Police Museum, Dannevirke, 28 October 2011.

Figure 19. Interior of garage attached to carport. Frame-grab taken from 86 interview footage captured at The International Police Museum, Dannevirke, 28 October 2011. 
Figure 20-21. Jean Hall's lace collection grouped according to style.

Frame-grabs taken from interview footage captured at Lillia's Lace Museum, Geraldine, 23 October 2011.

Figure 22. Items from Jim Barr's collection. Frame-grab taken from interview footage captured at Jim Barr's Wellington apartment, 03 October 2011.

Figure 23. A selection of Alison Reid's Crown Lynn Colour Glaze collection. Frame-grab taken from interview footage captured at Alison Reid's house, Auckland, 17 October 2011.

Figure 24. Items from Peter Smith's Stuart Crystal collection as they were exhibited at the National Antique and Bottle Collectables Show in Lower Hutt. Image courtesy of Peter Smith.

Figure 25. Items from Peter Smith's Crown Lynn collection as they were exhibited at the National Antique and Bottle Collectables Show in Lower Hutt. Image courtesy of Peter Smith.

Figure 26. Peter Smith's Lalique hood ornament as it was exhibited at the National Antique and Bottle Collectables Show in Lower Hutt. Image courtesy of Peter Smith.

Figure 27. Ian Ladds's calcite collection. Frame-grab taken from interview 90 footage captured in Ian Ladds's residential shed, Nelson, 21 October 2011.

Figure 28. Possum, White Tail deer specimens with labels. Frame-grab taken from interview footage captured at the Kahutara Taxidermy Gallery, Featherston, 07 October 2011.

Figure 29-30. Texts accompanying Jean Hall's lace collection. Frame-grabs 91 taken from interview footage captured at Lillia's Lace Museum, Geraldine, 23 October 2011. 
Figure 31. The International Police Museum entrance featuring Bruce Lyon's Motor Guzzi. Frame-grab taken from interview footage captured at The International Police Museum, Dannevirke, 28 October 2011.

Figure 32. Background - alcove that John McCosh built for the Robertson Bird 95 Collection. Foreground - John McCosh's collection featuring one-year-old crocodile. Frame-grab taken from interview footage captured at the Kahutara Taxidermy Gallery, Featherston, 07 October 2011.

Figure 33. 1925-1926 Dunedin Exhibition souvenir restored by Jean Hall. Image courtesy of Jean Hall.

Figure 34. Marlin restored by John McCosh. Frame-grab taken from interview 99 footage captured at the Kahutara Taxidermy Gallery, Featherston, 07 October 2011. 


\section{Acknowledgements}

This thesis would not have been possible without the generosity and support of many people.

Thanks are owed to The New Zealand Film Archive, who not only provided the financial means, which enabled me to undertake this thesis, but also generously allowed me a year off full-time work to do so. Particular thanks are owed to Huia Kopua, Sarah Davy, David Coventry and Owen Mann for making this possible.

I am exceptionally grateful to my supervisor Dr Lee Davidson, whose superb direction, feedback, and emotional support kept me sane.

Thanks are also owed to my brother Tane Griffin and mother Vi Griffin who offered me the necessities of life: shelter, food and love when it all got a bit bleak. To Frank Griffin for his unwavering commitment and support with a plethora of drafts, and to Stef Animal who was subject to what must have felt like seemingly endless conversations about private collectors, your support came in too many forms to list thankyou. Thanks also to a community of friends who were exposed to the highs and lows that a Master's year can bring, I am unsure where I would be without you.

Finally special thanks are owed to the following collectors whose perspectives I have tried to express: Jim Barr, Fiona Campbell, Jean Hall, Ian Ladds, Bruce Lyon, John McCosh, Alison Reid and Peter Smith. You have and will continue to inspire me! 


\begin{abstract}
Private collectors who share their collections publicly provide a valuable service to the public. They collect and provide access to cultural heritage materials just as public institutions such as museums and galleries within the heritage sector do. While there is a wealth of literature that discusses the significance of publicly funded heritage institutions to the heritage sector there is an absence of literature that explores the private collector's relationship to the heritage sector from their perspective. Literature on private collectors has tended to privilege the perspectives of publicly funded heritage institutions, affirming these institutions as the best place for the care and access to heritage collections. None of this literature or research has considered the private collector's perspective as a means to better understand their collecting activities or their position in relation to the heritage sector. This thesis places the private collector at the centre of enquiry. It explores the private collector's position in relation to the heritage sector through examining their perceptions and collecting practices relative to publicly funded heritage institutions.
\end{abstract}

Audiovisual interviews were conducted with eight private collectors to achieve this aim. Verbal and observational data captured through this method was analyzed and considered in relation to existing literature regarding the values and practices of public heritage institutions, as well as sociological theories of agency. Findings showed that there is a shared ethos between the private collector and the publicly funded heritage institution. This ethos is founded on common values and collecting practices. Findings also reveal that the individual agency of the private collector offers them autonomy in their collecting activities. This autonomy causes them to enact their collecting practices in accordance with their own subjective tastes. These tastes distinguish the private collector and their collecting practices from publicly funded heritage institutions and assist in identifying the private collector's position in relation to the heritage sector.

This research contributes to a canon of international and national research into private collectors and evaluative judgments regarding collecting. It enhances the publicly funded heritage institutions potential to collaborate with private collectors through providing a deeper understanding of their perspectives and practices. 


\section{Introduction}

The heritage sector has relied heavily on the skills and generosity of private collectors. Many of the oldest heritage institutions have been established through the acquisition of private collectors' collections (Belk 1995; Cameron 2004; Hedstrom and King 2003) and many modern heritage institutions continue to use the collections of private collectors for purposes of public display (Francis 1996). Yet despite the publicly funded heritage institution's reliance on the private collector, it is observed that there is a discrepancy in the status afforded to each. 'Notwithstanding their munificence,' Joseph Sax states, 'collectors have always been the objects of criticism, reviled as avaricious hoarders, or condemned for seeking social position by identifying themselves with greatness' (Sax 1999, 61). In contrast, the publicly funded heritage institution has escaped such disdain by virtue of its symbolic capital (Bourdieu 1993; Bennett 1995), perceived objectivity (Hooper-Greenhill 1989; Shelton 2001), integrity and service to the community (Weil 2002; Knell 2004). These distinctions are enshrined in a body of literature that emphasizes the importance of the publicly funded heritage institution and endorses its position as the best place for the provision of public access to collections. The private collector's perception of publicly funded heritage institutions and their position in relation to the heritage sector have yet to be included in this literature.

This research is an attempt to redress the imbalance. It explores the perceptions and practices of private collectors who share their collections publicly as a means to position them in relation to the heritage sector. It defines the heritage sector as a network of public and private heritage institutions and individuals that care for and make accessible items of cultural heritage significance for present and future generations (Controller and Auditor General 2006). This includes both publicly funded institutions such as museums, art galleries and archives as well as private institutions, communities and individuals (Gauteng Provincial Government, Department of Sport, Arts, Culture and Recreation 2008, 148). In seeking to understand the private collector's position in relation to the heritage sector, I compare their perceptions and practices to those of the publicly funded museum. The identification of areas of commonality and difference between the two protagonists provides a practical means by which to situate the private collector in relation to the 
heritage sector. In taking this approach I adopt Sharon Macdonald's view that 'collecting is fundamentally museological, whether the museum is directly involved or not,' and that 'the study of collecting - whether undertaken by a museum or not is best carried out under the rubric of museum studies' (Macdonald 2006, 95). This perspective explains why the publicly funded museum is used as a vehicle to compare the perceptions and practices of private collectors and why this research is situated within the field of museum studies.

The absence of the private collector's perspective has many ramifications and potentially negative connotations. If the publicly funded heritage institution does not properly understand the perspectives of private collectors it will constrain their ability to collaborate in meaningful ways (Moore 1997). This is particularly pertinent for heritage institutions that rely on government funding in New Zealand. In a recent ministerial report, produced by the Cultural Philanthropy Taskforce for the Minister for Arts, Culture and Heritage, Hon Christopher Finlayson, it was suggested that stronger relationships between private individuals and cultural organizations needed to be forged to secure the future of the cultural sector. 'Government support can only ever be one part of an overall strategy for the cultural sector', the report states, 'it's now time to ensure the cultural sector plays its part' (Cultural Philanthropy Taskforce 2010, 3). The taskforce recommended that the government should 'reward with matched government funding cultural organisations that succeed in increasing their levels of income derived from private giving' (Cultural Philanthropy Taskforce 2010, 3). It further suggested that "private philanthropy is more than just giving money. The donation of time, energy and skills to cultural organisations by generous and committed people is also of great value' (Cultural Philanthropy Taskforce 2010, 4). It would be helpful then if additional research were undertaken to clarify the perspectives and motivations of private individuals who have resources and skills that are of value to the publicly funded heritage institutions.

The rapid proliferation of private collections and private museums has also been identified as a threat to publicly funded heritage institutions (Hagan 2011). Their increase has seen more objects going into private hands, and has added an additional level of competition for audience engagement among publicly funded heritage institutions (Hagan 2011). This demands a better understanding of the motives of 
these private collectors. Without understanding why private collectors acquire and share their collections publicly, publicly funded heritage institutions will potentially miss out on deposits from private collectors, and fail to understand their competitors.

Moreover, private collectors form part of the public that the publicly funded heritage institutions are mandated to serve. This accountability is clearly documented in the International Council of Museums (ICOM) Code of Ethics for Museums, in which it is stated:

Museums have an important duty to develop their educational role and attract wider audiences from the community, locality, or group they serve. Interaction with the constituent community and promotion of their heritage is an integral part of the educational role of the museum (International Council of Museums 2006, 8).

As a consequence, improved understanding of how the private collector perceives of publicly funded heritage institutions is of considerable interest.

I was drawn to this area of research because of my professional experiences working at The New Zealand Film Archive. The New Zealand Film Archive is an independent charitable trust. Its collection consists of over 150,000 items that have been voluntarily deposited by production companies and members of the public. Consequently The Film Archive is heavily reliant on the generosity of private individuals, and works hard to foster relationships with private collectors. My role as Research Librarian at The New Zealand Film Archive has been to connect people with New Zealand's moving image heritage through managing the acquisition, arrangement and description, preservation, and provision of access to a variety of archival media. My experience with depositors has taught me that there are many private individuals who feel as committed to the preservation and access of heritage materials as my colleagues do. Their commitment has stimulated my academic interest in private collectors who make their collections publicly accessible.

The overall aim of this research was to position the private collector in relation to the heritage sector from the private collector's perspective. In order to understand this 
perspective it was felt necessary to gain an insight into their motives, values and collecting practices. This was achieved by the use of in-depth audio-visual interviews to address the following research questions:

1. How do private collectors perceive of the heritage sector and their relationship to it?

2. What values (private / public / institutional) motivate the private collector to share their collections publicly?

3. What do the collecting practices (acquisition, storage, cataloguing, display) of the private collector entail? And how do these relate to the institutional collecting practices of the heritage sector?

4. What future does the private collector envisage for their collection?

In seeking to find answers to these questions I acknowledged that value circulated in three domains: private, public, and institutional. I reserved the term 'private value' for the meaning individual collectors attributed to their collections and the activity of sharing their collections publicly. I used the term 'public value' to represent the meaning attributed to these activities by 'members of society at large' (Richins 1994, 504). 'Institutional values' are reflected in literature produced by the heritage sector and enacted through their collecting practices. These values were considered in terms of the conscious or unconscious influence they have over private collectors. I defined 'collecting practices' as the collection, conservation and display activities of the private collector.

This research offers an insight into the perceptions and collecting practices of private collectors who share their collections publicly. It contributes to the field of museum studies by drawing on museum history, theory and practice to explore the intersections and impasses of the activities of the private collector in relation to those of publicly funded heritage institutions. This comparison assists in situating the private collector in relation to the heritage sector and benefits publicly funded heritage institutions by providing a deeper understanding of private individuals with whom 
they are encouraged to collaborate. This understanding can inform publicly funded heritage institutions engagement with private collectors as both potential collaborators and as members of the audience they are obligated to serve. The archiving of 'raw' data generated in this study offers additional benefits. It provides a resource that other researchers and members of the public can use to explore a broader range of topics, not just the private collector's position in relation the heritage sector, which it was my intention to focus on.

The rest of this thesis consists of three chapters. Chapter One is divided into two sections. The first section examines literature that is relevant to the objectives of the research and literature that has informed my analysis of the findings. It discusses the historic relationship between private collectors and the public museum, and identifies binaries that have traditionally been used to distinguish the collecting activities of private collectors from publicly funded heritage institutions within the heritage sector. It explores how the boundaries between heritage institutions and private collectors are blurred and evaluates guidelines and models that govern the collecting practices of heritage institutions. The need for additional research into the perspectives and collecting practices of private collectors is demonstrated through an analysis of previous research. This is followed by an examination of literature that has helped inform my analysis. It discusses the relevance of Bourdieu's theories of the habitus and the field as well as his recognition of capital as a means to position agents in relation to broader societal structures. The relevance of actor-network theory and Robert Stebbins's concept of the social world is also discussed. The second section describes the research process. It outlines my methodological approach, further detailing the methods employed to collect and interpret empirical data.

Chapter Two presents the findings to my first two research questions. It includes biographical sketches of each of the participants that offer a context in which their perspectives may be understood. This is followed by a discussion of the private collector's perceptions of heritage institutions as audience members, collaborators and as 'non-professional' collecting peers. The values that motivate private collectors to share their collections publicly are then discussed. 
Chapter Three presents the findings to my third and fourth research questions. It considers the agency of the private collector in relation to the objects they collect and other people in their environment. It discusses and analyses the collecting practices of the private collectors relative to 'best practice' heritage sector standards, and considers the values that inform them. This chapter also discusses the future private collectors envisage their collections to have beyond their own lifespan.

These chapters are followed by the Conclusion, which summarises the major findings presented in Chapters Two and Three in relation to my overall aim. 


\section{Chapter One: Literature review and research design}

This chapter discusses relevant theory that framed my research and the analysis of its findings. It reviews existing literature and presents an overview of my research design. It begins with an examination of literature that places my study within the field of museum studies. This is followed by a review of literature that offers a framework in which to interpret my findings. Details regarding my research design are then presented.

\section{Review of relevant background literature}

Existing literature reveals that the relationship between the private collector and heritage institutions within the heritage sector is complex and multi-faceted. 'Museum and individual collecting have been argued to be mutually entangled', Sharon MacDonald states, 'not only literally with individual collections sometimes entering or even forming the basis of museums, but also in more subtle and ramifying ways' (McDonald 2006, 95). This literature review seeks to untangle the relationship between the private collector who shares their collections publicly and heritage institutions within the heritage sector. It begins with an examination of literature that addresses the historic relationship between the private collector and the public museum. In doing so it identifies areas of commonality between the activities of the private collector and heritage institutions within the heritage sector. The boundaries used to distinguish the private collector from heritage institutions are then explored. This is followed by a discussion of how values and evaluative judgments associated with the activity of collecting blur the boundaries between private collectors and heritage institutions within the heritage sector.

Despite the extensive literature that addresses the relationship between private collectors and heritage institutions within the heritage sector, there is an absence of literature that addresses the private collector's position in relation to the heritage sector from their perspective. Consequently this review draws on wider literature that examines museum history, theory and practice more generally. This approach is compatible with the field of museum studies (Labrum and McCarthy 2005). It is a field of inquiry that has been credited for its ability to negotiate meaning 'at the boundaries and overlaps of communities' (Macleod 2001, 59). My research addresses 
a void in this area and extrapolates from a limited number of studies that have sought to examine the relationship between private collectors who share their collections publicly and heritage institutions within the heritage sector. These studies are discussed at the end of this review.

\section{The historic relationship between the private collector and the heritage sector}

In an attempt to understand the connection between private collectors and the heritage sector it was considered pivotal to understand where the origins of their relationship lay. This led to an examination of literature that concerned the history of private collectors and the public museum. It showed that private collections, consisting of 'the workings of nature [along] with the creations of man', were a precursor to the museum, in the European museological tradition (Yaya 2008, 174). Known as 'Cabinets of Curiosity' or 'Wonder Cabinets' these structures emerged during the $17^{\text {th }}$ century as 'a form of entertainment that slowly evolved into a deliberate practice of collecting' (Hedstrom and King 2003, 5). They contained Greek and Roman antiquities, works by Durer, Rubens and Cellini, 'as well as items that were intriguingly rare or possessed some affinity with the world of fables...deformed or atypical beings such as dwarves and giants, rare botanical specimens, unicorn horns, fossils and corals' (Yaya 2008, 174-175). The contents of these collections were arranged in one or more rooms of private houses, usually categorized into taxonomic groupings based on the physical properties of collected items (Pearce 1992). The creators of these collections have been credited for their systematic collecting activities:

While novelty was the impetus to early Renaissance collecting and the stimulation of marvel was its goal, collecting can also be a method of systematically assembling, ordering, and symbolically controlling the chaos that novelty threatens to create. The exhilarating sense of discovery and encyclopaedic knowledge gave way first to greater classification and specialization in these cabinets (Belk 1995, 32).

The innovators of these collections have also been praised for providing public access 
in a manner capable of merging entertainment with public education (Belk 1995). Shared with members of the public, at the private collector's discretion, 'the initial purpose of these collections was simply to elicit wonder, but the act of wondering led soon to inquiring and theorizing' (Hedstrom and King 2003, 9). This concept is used to define the publicly funded museum, as we know it today:

A museum is a...permanent institution in the service of society and its development, open to the public, which acquires, conserves, researches, communicates and exhibits the tangible and intangible heritage of humanity and its environment for the purposes of education, study and enjoyment (ICOM Statutes of the International Council of Museums 2007, in International Council of Museums 2009, 57).

The importance of these private collections and their creators to the public museum is conveyed in literature, which acknowledges that the 'first museum in the modern world' - the Ashmolean Museum - was founded on a cabinet of curiosity (Hedstrom and King 2003, 6). Its contents of 'natural-history objects, weapons, medals, garments, books, household utensils' had originally been collected by John Tradescant and his son between 1610 and 1662, and was exhibited to the general public as a tourist attraction called 'The Ark' (Belk 1995, 42). Elias Ashmole, a lawyer, astrologer and alchemist, acquired the collection after the Tradescants' death. He subsequently gifted the collection to Oxford University in 1683 (Hedstrom and King 2003). Motivated to accept the deposit because of an 'intellectual curiosity, an inherent sense of the value of the objects, and the social prestige associated with them', the university dubbed their acquisition the 'Ashmolean Museum' in Ashmole's honour (Kell 2004, 79). The Ashmolean Museum validates Duncan Cameron's claim that the first public museums essentially offered the public 'private collections but with a new name over the door' (Cameron 2004, 66).

The appropriation of private collectors' collections is a practice still common to heritage institutions today; 'museums and galleries', Robin Francis states, 'have long maintained close links with private collectors and drawn on their collections for exhibition purposes' (Francis 1996, para.5). This begs the question, in light of the 
heritage institutions' enduring relationship with the private collector and the identification of shared practices, how have the two been distinguished?

\section{Established boundaries that distinguish the private collector from heritage institutions}

The exploration of points of distinction between the private collector and heritage institutions within the heritage sector highlighted the paucity of literature that considered the private collector's perspective. As a result this literature review examines points of difference from the publicly funded heritage institution's perspective. These points of difference are encapsulated in the following binaries: Public/Private; Institutional/Individual collecting practices; and Professional/Amateur.

\section{Public/Private}

According to Eileen Hooper-Greenhill a key point of distinction between the public heritage institution and the private collector may be seen in the Enlightenment ideal of democratisation. She observes that during the $18^{\text {th }}$ century the museum became an:

apparatus that articulated a new ensemble of oppositions within a new regime of truth. The oppositions include private/public, closed/open, tyranny/liberty, superstition/knowledge, inherited wealth/courage... with the concept of the museum as an instrument for the democratic education of the "masses", or the "citizen", a division [was] created between...producers and consumers of knowledge, expert and layman (Hooper-Greenhill 1989, para.33).

Literature reveals that the flipside of the perceived objectivity of public museums was the view of private collectors as subjective citizens. As subjective citizens, their motives were not free from public scrutiny or contention. The private collectors' facilitation of public access to their collections was treated with suspicion, and any benevolent intent was clouded by their desire to be seen as 'great' (Sax 1999, 61). This is in contradiction to the image of the public museum, whose work was seen as an admirable service for the public good (Hooper-Greenhill 1989).

In order to comprehend the public/private divide purported in this literature, it is 
necessary to establish an understanding about who, or what, constitutes the 'public' that museums 'objectively' strive to serve. The International Council of Museums (ICOM) coda Key Concepts in Museology defines the term 'public' in two ways:

The adjective 'public'- as in 'public museum'...causes museums worldwide to see their activities carried out, if not under the aegis of public authorities, then at least with reference to them, and most often to be partly run by these authorities, which in turn obliges museums to respect a number of rules which influence their administration and a number of ethical principles (International Council of Museums 2009, 70-71).

As a noun, the word 'public' refers to the museum users (the museum public), but also, by extension from its actual user public, to the whole of the population addressed by the establishment...The very notion of public closely associates the museum activities with its users, even those who are intended to benefit from it but do not use its services. By users we mean of course the visitors - the public at large (International Council of Museums 2009, 71-72).

The appreciation of the duality of the term public highlights how the public museum (the adjective) has a formal responsibility to serve the public (the noun). In a New Zealand context, the Controller and Auditor General state that the ethical obligations of the public museum/gallery are 'to provide proper storage, management, and care of collections in its possession,' ensuring objects owned, borrowed or held in its custody are made 'available and accessible to present and future generations' (Controller and Auditor General 2006, 25). The private collector is free from these ethical obligations and yet without any 'duty imposed by law or even at the strictures of public opinion', Joseph Sax contends, many private collectors willingly share their collections, bridging these public and private imperatives (Sax 1999, 72).

This places the private collector, who shares their collections publicly, in a unique position. These collectors are both members of the public that publicly funded heritage institutions are mandated to serve, and are providers of services that parallel those of heritage institutions within the heritage sector. Private collectors' provision 
of public access to their collections has however been demeaned by literature that questions their competencies to do so.

\section{Institutional versus individual collecting practices}

Scepticism about the private collector's ability to preserve and provide public access to cultural heritage materials separates them from publicly funded heritage institutions in the minds of some. In reflecting on the future of collecting, Simon Knell claims that 'private collectors do not necessarily provide things with long-term prospects of survival, protected contexts or public access' (Knell 2004, 39). This view appears to have historic currency, as F.A. Lucas's 1896 letter to Science reveals:

A private collector may know his own needs, but he would not know or would not care for the needs of the public, and he would carry to a public museum the taste for accumulation, or for research, which probably led to the formation of his own collection. Accumulation is a good thing, but it needs to be properly directed in order to be of public service, while there is probably no greater drawback to the public efficiency of a museum officer than too great devotion to original research, as this leads not only to a lack of care for material which has served its turn, but to a very decided lack of interest in the public which must be reached through the exhibition series (Lucas 1896, 289).

Whilst Lucas's letter portrays the private collector as a committed individual with real research skills, it also echoes Knell's concerns about the capabilities of private collectors to care for and provide public access to collections. This reinforces the position of the publicly funded museum as the best environment to care for and display objects.

Tensions surrounding the 'best' environment for collections are not simply resolved through the adoption of the word 'museum' in an institution's title. Former museum professional Stephen Weil observes:

Museum people have a gut sense that all museums are not of equal quality, that some museums are better than others. At issue here is not mere personal preference, but an instinctive sense that - in common with every other human 
activity - not everybody is just as good as everyone else at operating a museum (Weil 2002, 4).

Weil qualifies this view by highlighting 'the museum field's incessant efforts at selfimprovement, through training, meetings, courses of study, [and] publications... premised on...a determination to see museums made more "better" and less "worse" (Weil 2002, 4).

One area of self-improvement that has received considerable attention in heritage sector literature is the field of 'collections management' (Knell 1994; Fahy 1995; Lord and Dexter Lord 1997). It is defined in ICOM's Running a Museum: A Practical Handbook as 'the term applied to the various legal, ethical, technical, and practical methods by which museum collections are assembled, organized, researched, interpreted, and preserved' (Ladkin 2004, 17). Collections management may be understood, as an inclusive term that encompasses the institutional collecting practices of acquisition, cataloguing, storage and display.

An overarching theme that links these collecting practices is the concept of 'best practice' (Edson and Dean 1994). Promoted in New Zealand by heritage sector professional organizations such as Museums Aotearoa, and National Services Te Paerangi, best practice standards inform policies and establish benchmarks that are commonly used to govern and measure the performance of museums, art galleries and archives in New Zealand (Museum of New Zealand Te Papa Tongarewa 2007). Resource guides and a standards scheme have been produced for the heritage sector by The Museum of New Zealand Te Papa Tongarewa's National Services Te Paerangi division 'and are increasingly being adopted by individual museums and galleries' (Museums Aotearoa Te Tari o Ngā Whare Taonga o te Motu 2005, 15). These benchmarks are synonymous with those of 'better' museums in accordance with the view espoused by Weil.

The absence of research into the collecting practices of private collectors who share their collections publicly leaves the unfounded criticisms of Knell and Lucas to resonate. Further research into the collecting practices of private collectors is required not only to examine the validity of these claims, but to fill a gap in existing literature. 


\section{Professional/Amateur}

Another way of thinking about the distinction between the collecting activities of private collectors and heritage institutions within the heritage sector is to consider their professional standing. Defining museum work as a profession is a difficult task, as ICOM admits: 'for a profession to exist...it must define itself as such, and also be recognized as such by others, which is not always the case in the museum world' (International Council of Museums 2009, 67). Some theorists have speculated that the very construct of a 'museum profession' originated as a means to justify public expenditure on the museum in times of financial hardship during the 1980s (Harrison 1993). ICOM attempts to sidestep the difficulty in making a clear distinction between 'professionals' and 'non-professionals'. It does so by identifying the types of employees one may find in a museum: curators, conservators and registrars (International Council of Museums 2009). These employees, according to ICOM statutes, are also defined by their specialist skills:

All the personnel of museums or institutions qualifying as museums in accordance with the definition in Article 2, para.1, having received specialized training, or possessing equivalent practical experience, in any field relevant to the management and operations of a museum, and independent persons respecting the ICOM Code of Professional Ethics and working for museums as defined above, either in a professional or advisory capacity (International Council of Museums Statutes Article 2.2, in Boylan 2006, 423).

They are also bound by a code of ethics that obligates the museum professional to share their knowledge with others:

Members of the museum profession have an obligation to share their knowledge and experience... They should respect and acknowledge those from who they have learned and should pass on such advancements in techniques and experience that may be of benefit to others without thought of personal gain (ICOM Code of Ethics for Museums para.8.2, in Boylan 2006, 425).

The 'public museum professional' may be seen then as an individual who is employed in a particular role within a specific setting - the public museum - and is ethically 
obligated to share their skills with others. Private collectors are excluded from this definition on the basis they do not work within publicly funded heritage institutions.

In an attempt to better understand the divisions between private individuals with collection related skills, and museum workers, Morgan Meyer (2008) undertook a study of amateur scientists within the setting of a public museum. He concluded that boundaries between amateurs (private individuals) and professionals (museum workers) are 'revealed through temporal, spatial and material processes' (Meyer 2008, 48). Further stating that to study amateurs:

One needs, then, to move beyond the simple a priori assertion that there is one group of persons that can be called amateurs. Instead, it is through the study of (partial) connectivities, that one can get a better grasp of the identities, practices, and roles of amateurs. This means considering amateurism not as an essence, but as relationally defined through fragile connections and demarcations (Meyer 2008, 48-49).

Meyer's distinction between the amateur and the professional within the museum is about deadlines, physical space and tools the professional have at their disposal. He claims that the adoption or rejection of any or all of these things by the amateur confuses the agency between the two (Meyer 2008).

Robert Stebbins, who has written extensively on what he terms 'serious leisure' activities, classifies collectors as 'hobbyists' rather than 'amateurs' (Stebbins 2007, 8). He does so on the basis they have no professional counterparts (Stebbins 2007). While this conclusion is questionable, Stebbins's analysis of the professionalamateur-public (P-A-P) system (see Stebbins 1977; 1992; 2002) is illuminating. Devised and defined by Stebbins, the P-A-P system reflects a set of 'functionally interdependent relationships' between professionals, amateurs and their publics (Stebbins 1977, 585). Stebbins contends that in this system publics 'seem to be as prevalent and important for hobbyists... as for amateurs' (Stebbins 1992, 11). He further claims that 'hobbyists are often enamoured [with] pursuits bearing little or no resemblance to ordinary work roles' (Stebbins 1992, 11). This failure to connect with a professional counterpart not only excludes the hobbyist from this system but also 
distinguishes the hobbyist from the amateur: 'If amateurs in general, have no idea of the prowess of their professional counterparts, the latter become irrelevant as role models, and the leisure side of the activity remains at a hobbyist level' (Stebbins 2007, 6-7). In defining the private collector as a hobbyist, Stebbins therefore suggests that they do not view heritage workers as having specialist skills.

\section{How values and evaluative judgements regarding collecting blur boundaries}

The previous section observed that the characteristics used to distinguish the private collectors from heritage institutions within the heritage sector, have been defined from the heritage institution's perspective. Given that the private collector's view is absent in this literature one can assume these distinctions are largely founded on evaluative judgments regarding the private collector, and their collecting activities. This highlights the influence value judgments play in positioning agents within the heritage sector. This section examines evaluative judgments regarding the activity of collecting and studies that explore value. In doing so it interrogates how the boundaries between the private collector and heritage institutions within the heritage sector are blurred.

James Clifford observes that the categories or value systems most commonly found in the literature, surrounding collecting and collections include aesthetic, taxonomic, economic, cultural and scientific worth (Clifford 1988). These values are reflected in Susan Pearce's figure 'Axes of value in objects and collections' (Figure 1) (Pearce 1998, 41). Originally printed in Collecting in Contemporary Practice, the figure reflects findings from Leicester University's 1993 study 'The Contemporary Collecting in Britain Survey', which investigated the collecting habits and the types of material collected by private collectors in Britain. ${ }^{1}$ It appropriates the use of 'semiotic squares' (attributed to Griemas, Rastier and Clifford) to illustrate how objects can traverse two conceptual axes 'Masterpiece - Artefact' and 'Authentic / Quality Non-authentic, Spurious / Rubbish' (Pearce 1998, 40). The four quadrants comprising the inner circle of Pearce's figure represent the types of material collected.

\footnotetext{
1 The study involved "the distribution of 1,500 questionnaires to randomly chosen individuals with the aim of discovering both quantitative and qualitative information about collecting habits and the nature of material'
} 
This provides a model system to plot and contest objects' value based on the physical and intellectual properties of the materials collected. Its capacity to understand the value of collecting encompasses both the private collector and publicly funded heritage institutions, by focussing on the objects they collect.

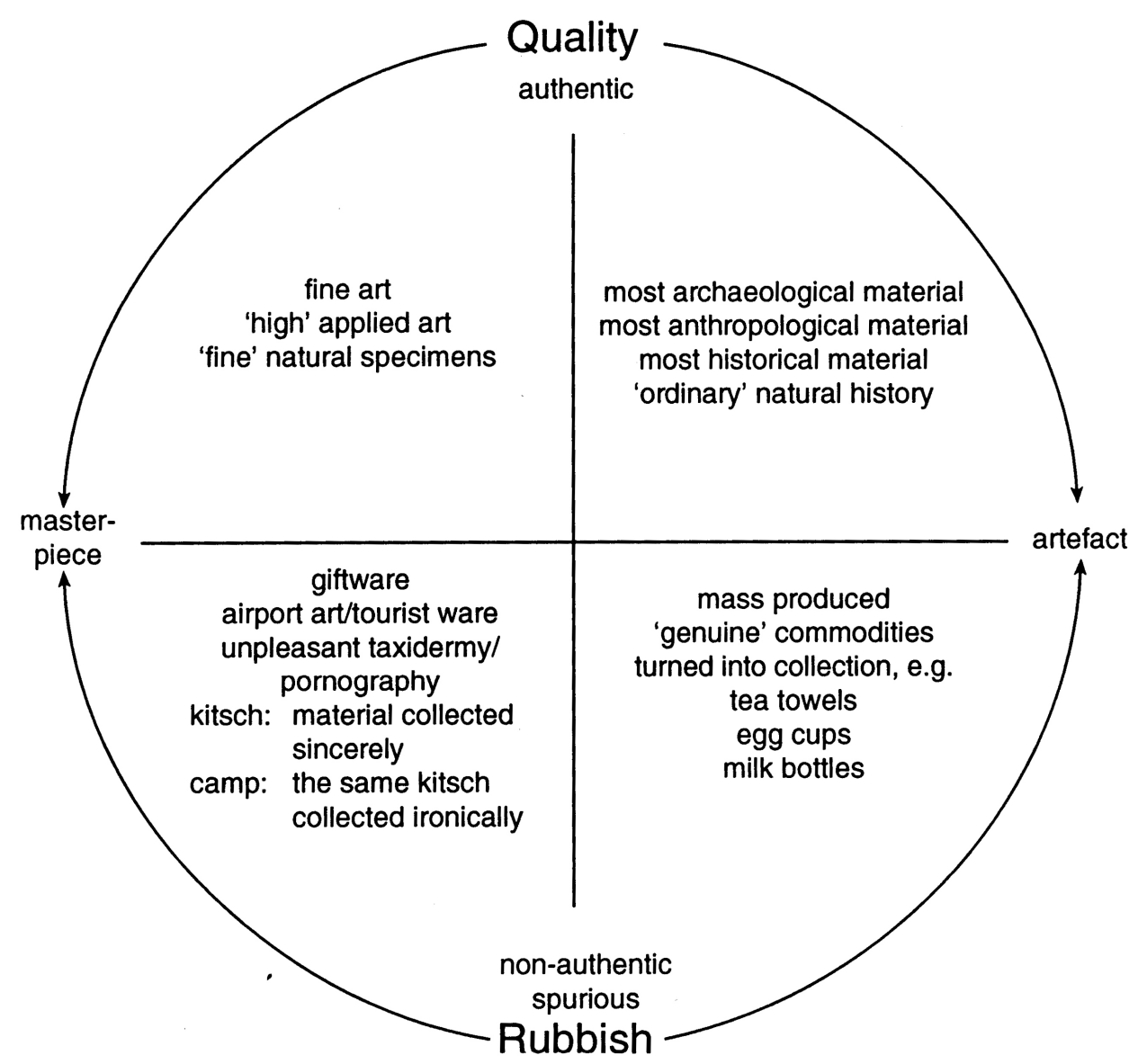

Figure 1. 'Axes of value in objects and collections' (Pearce 1998, 41).

Pearce extended the concept further to show the relationship between sites of display and notions of 'authenticity' in her diagram 'Collecting in relation to perceived valuation' (Figure 2) (Pearce 1998, 93). In this classification Pearce nominates the 'Public collection' as the place where 'objects beyond value - Quality / heritage' can be located (Pearce 1998, 93). It contrasts these from the 'Rubbish / Private Collection' where 'non authentic, spurious objects' can be found (Pearce 1998, 93). This figure attempts to elucidate how the activity of public display shapes values associated with collecting. According to Pearce, the key to understanding how objects traverse such a schema is to grasp that 'value is not finite or fixed with the intense feelings of the collector over time [becoming] the mechanism through which private pastoral can, 
sometimes, become public value' (Pearce 1998, 93). Pearce's concept is consistent with James Clifford's belief that the concept of 'authenticity' has 'as much to do with an inventive present as with a past, its objectification, preservation, or revival' (Clifford 1988, 222). This raises questions regarding how the practice of public display determines the valuation of collections and collectors.

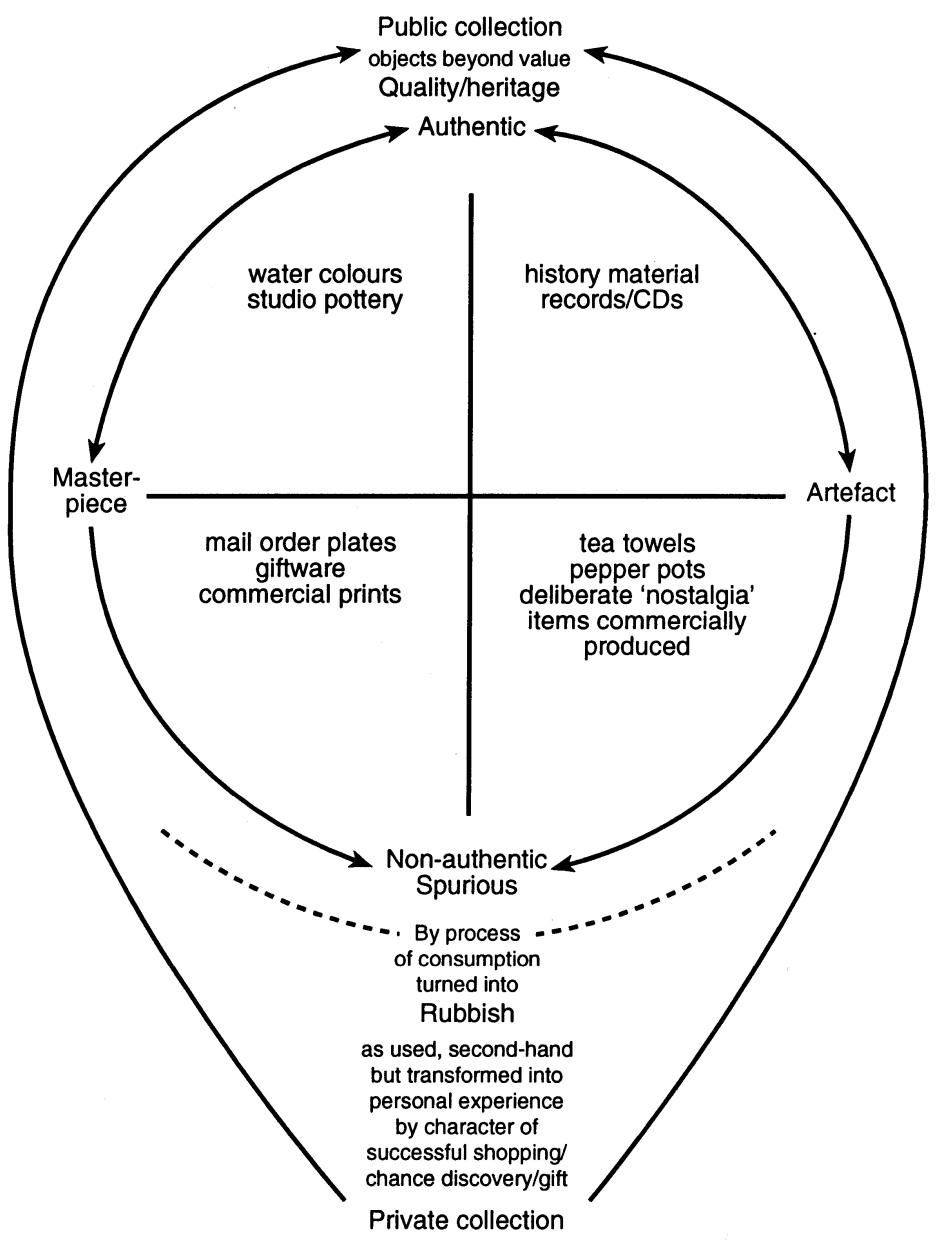

Figure 2. 'Collecting in relation to perceived valuation' (Pearce 1998, 93).

Another way to conceive of value is to consider how the concept is applied in the collecting activities of heritage institutions within the heritage sector. This topic has been explored systematically in the Heritage Collections Council of Australia publication Significance 2.0 (Russell and Winkworth 2009). It aims to give collection managers and collecting organizations a 'shared framework and standard process to analyze and communicate the meanings and values of collections' (Russell and Winkworth 2009, 1). It defines the concept of significance as 'the historic, artistic, scientific and social or spiritual values that items and collections have for past, present 
and future generations', and states that 'these are the criteria or key values that help to express how and why an item or collection is significant' (Russell and Winkworth 2009, 10).

There are a number of studies exploring value that offer a deeper understanding of how private and public values are produced and negotiated. The benefit of these studies is the insight they provide into how values can be shared between individuals and societal groups. These studies include Marsha Richins's (1994) study into the private and public meanings of consumer possessions, Rebecca Morrison's (2010) study into the meaning-making processes of toy collectors, and Chloe Searle's (2010) research on the private and public values surrounding what is collected by New Zealand's national museum The Museum of New Zealand Te Papa Tongarewa.

Richins (1994) used empirical data to study the private and public meanings of consumer possessions. ${ }^{2}$ She defined private meanings as those meanings ascribed to a possession by its owner, and public meaning as the meaning ascribed to it by 'members of society at large' (Richins 1994, 504). Findings in her study lead her to conclude that 'a possession's public and private meanings are what give it value,' and that 'meaning is multiply determined and multidimensional' (Richins 1994, 504). She found that private meanings consist of 'public meanings shaped by the private knowledge and experiences of the possessor with respect to the particular object he or she owns' (Richins 1994, 517). Although this research is not specific to private collectors, its consideration of how private and public values influence one another is useful when considering the values that motivate private collectors to collect and share their collections publicly.

The subject of meaning making in private collecting is the topic of a recent Doctoral thesis by Rebecca Morrison (2010). Morrison studied Canadian toy collectors to explore 'how collectibles are made meaningful within collecting communities' (Morrison 2010, iii). She analysed data gathered from 33 interviews with toy collectors, in combination with observations she conducted at toy fairs. Morrison concluded that central to the collector's fascination with their collectibles is the

\footnotetext{
${ }^{2}$ Richins's methods included a mail survey (Study 1 - private meaning); an activity to sort a deck of cards into piles 'with each card listing one of the possessions generated in study one' (Study 2 - public meaning); and questionnaires (Study 3 - private and public meaning) (Richins 1994, 508-515).
} 
malleability of their objects' meaning, determined through the navigation of both personal and wider cultural understandings (Morrison 2010). This raises the question of the role the heritage sector plays in shaping the wider cultural understandings that inform the personal values of private collectors.

Chloe Searle (2010) explored the relationship between heritage sector values and those of private individuals in a New Zealand context. She did so by examining the significance history curators at The Museum of New Zealand Te Papa Tongarewa placed on the objects they collect in relation to what members of the public thought Te Papa should collect. Researching Te Papa's collecting policies, conducting public focus groups and interviewing curators, she found that many of the significances placed on collected objects were shared between curators and members of the public (Searle 2010). These values included the financial, aesthetic, historic, subjective and temporal significance of objects (Searle 2010). This raises the question of whether these values are synonymous with those that motivate private collectors to collect and share their collections publicly.

\section{Studies regarding private collectors and the heritage sector}

There has been a wealth of research into the topic of private collectors. These studies originate from a vast array of disciplines: anthropology (Clifford 1988); consumer research (Belk et al. 1988; Belk 1995); sociology (Dannefer 1980; Moulin 1987); art history (Sasselin 1984); psychology (Csikszentmihayli and Rochberg-Halton 1981; McIntosh and Schmeichel 2004); music studies (Shuker 2004); and museum studies (Pearce 1995; Martin 1999; Evans 2002). This research has tended to focus on the psychology and behaviours of collecting as an individual pursuit. It has sought to explore how the activity of collecting is made meaningful to individuals who collect. None of this research has considered how the meaning private collectors place on the objects they collect or their collecting activities positions them in relation to the heritage sector. Those limited studies that have considered the private collector's position in relation to the heritage sector have focussed on the relationship between private collectors and publicly funded heritage institutions. These studies include: Janine Lovatt's research into private collectors who participated in the Walsall Museum and Art Gallery's The People's Show (Lovatt in Pearce 1998) and Ariel 
Hagan's recent research into the relationship between private art collectors and public museums (Hagan 2011).

Lovatt's research concerns data from collectors who participated in the Walsall Museum and Art Gallery's, The People's Show. Instigated in 1990 by the Walsall Museum and Art Gallery in West Midlands, England, The People's Show exhibited the collections of local people, solicited through advertisements in the local press. The event's success led to the concept being repeated several times, including a nationwide festival in 1994 that was said to have attracted 'one million people' to see 'more than half a million objects on loan from five hundred local collectors' (Francis 1996, para.7). Credited for their contribution to the equal opportunity debate - which dealt with issues such as 'breaking down barriers, accessing museums, de-mystifying the profession, and validating popular culture' - The People's Shows were also criticised for exploiting private collectors:

The People's Show has been criticised for being little better than a freak show a politically incorrect but, sadly, perennially popular form of entertainment. Collectors are often perceived as being figures of fun...they have been associated with eccentric and obsessional behaviour (Francis 1996, para.16).

Quantitative data obtained by Lovatt from the 1994 People's Show nationwide festival revealed that most of the participating (201) collectors were motivated to share their collections publicly 'for enjoyment and interest to others' (37\%), and 'to teach and share knowledge' (31\%), with only (11\%) being motivated by 'personal pride' (Lovatt in Pearce 1998, 66-68). One can infer from this data that the motivation of collectors to be seen as 'great' is less important than their civic sensibilities, and more closely aligned with the public museum imperative of sharing for purposes of education and public good. Contrary to this evidence, Susan Pearce's analysis of Lovatt's findings led her to assert that the collectors' motives are 'presumably shadowed by the idea that exhibition of the collection also exhibited the collector in a good light' (Pearce 1998, 66). This reinforces the stereotype of the collector as an egotist and suggests that the private collector's association with a museum is capable of elevating their status. The inconsistency between these two interpretations suggests there is a need for qualitative research that privileges the perspectives of private 
collectors who share their collections publicly.

The relationship between the private collector and the publicly funded museum has recently been examined in Hagan's 2011 study into the perceptions and practices of private collectors. In it she 'aimed to assess the current conditions' between the public art museum and the private art collector to 'better understand possible directions in which these relationships may be heading' (Hagan 2011, 73). Hagan did so by examining three methods in which art is made publicly accessible: public museums, museums privately funded by collectors, and collaborative partnerships between private collectors and publicly museums (Hagan 2011,2). She analyzed media articles and conducted interviews with publicly funded heritage institution staff and art collectors. Hagan found that while the collecting activities of the private collector and the public museum were distinct - because of the status and skills found within the public art gallery, and the private collector's personal ambitions and tastes - there was potential for 'successful' and 'healthy' partnerships (Hagan 2011,2). The specific focus of Hagan's research into art collectors and public museums suggests additional research into the collectors of diverse media would also be beneficial. Such research would facilitate a better understanding of potential relationships between private collectors and publicly funded heritage institutions within the heritage sector.

\section{Summary}

This literature review relating to museum history, theory and practice, sought to explore the complexities and multi-faceted relationship between private collectors and publicly funded heritage institutions within the heritage sector. It identified areas of commonality between the collecting activities of public museums and private collectors. A review of literature into the differences between publicly funded heritage institutions and private collectors revealed that whilst we know how publicly funded heritage institutions perceive of private collectors we remain unaware about how private collectors perceive of publicly funded heritage institutions and their position in relation to the heritage sector. A review of research into the subject of private collectors reveals there is little research into the private collector's position in relation to the heritage sector. Findings from those studies that have addressed the topic reveal that there is a need for further qualitative research into the motives of private 
collectors (Lovatt in Pearce 1998) and a need for research into the perceptions and practices of a diverse range of collectors (Hagan 2011). My research is a response to this gap. It contributes to the field of museum studies by exploring the boundaries between private collectors who share their collections publicly and publicly funded heritage institutions, as a practical means by which to position the private collector in relation to the heritage sector.

My first research question is: How do private collectors perceive of the heritage sector and their relationship to it? This question is informed by the awareness that the private collector has a dual role. They are both members of the public that publicly funded heritage institutions within the heritage sector are mandated to serve (International Council of Museums 2009) and they provide a similar function to these institutions through providing public access to collections (Sax 1999; Hagan 2011). This question explores private collectors' perceptions of the heritage sector in each of these roles. In doing so it also considers whether the private collector recognizes the activities of heritage sector worker as those of the professional (Stebbins 2007) and if they distinguish their activities from heritage institutions within the heritage sector on this basis.

The second research question is: What values (private / public / institutional) motivate the private collector to share their collections publicly? This question is informed by the private collector's agency as a provider of access to collections (Sax 1999) and evaluative judgements associated with public display (Pearce 1998). It seeks to examine the accuracy of the criticism that the private collector is motivated to share their collections publicly because they wish to be seen as 'great' (Sax 1999; Pearce 1998). It considers whether wider cultural understandings (Richins 1994; Morrison 2010) shape the values private collectors place on their collecting activities and if these values are shared with heritage institutions within the heritage sector (Searle 2010).

The third research question is: What do the collecting practices (acquisition, storage, cataloguing, display) of the private collector entail, and how do these relate to the institutional collecting practices of the heritage sector? It seeks to fill the gap identified in literature regarding the collecting practices of private collectors who 
share their collections publicly. It appropriates best practice standards to better understand the collecting practices of the private collector in relation to heritage institutions within the heritage sector (Ladkin 2004; Museum of New Zealand Te Papa Tongarewa 2007). It also examines whether the values that infuse the private collector's collecting practices are synonymous with those of heritage institutions (Russell and Winkworth 2009).

The fourth research question is: What future does the private collector envisage for their collection? This question explores the private collector's position within the heritage sector in more subtle ways (Macdonald 2006). It seeks to understand whether the private collector sees heritage institutions within the heritage sector as an appropriate place to deposit their collections, like their predecessors (Belk 1995; Hedstrom and King 2003; Yaya 2008). In doing so it extrapolates from Hagan's (2011) research to explore the potential of partnerships between the private collector and heritage institutions within the heritage sector.

The literature reviewed in this section has offered a pragmatic framework for my research aim and questions. The next section discusses the relevance of a deeper sociological context to the analysis of my findings.

\section{Further relevant theory}

Because there is so little existing literature examining the private collector's perspective, I have explored other literature to help provide a theoretical framework for my topic. Central to my aim is a better understanding of the private collector's agency within the heritage sector. This section discusses theories of agency as enunciated by Pierre Bourdieu, actor-network theorists and Robert Stebbins. Together these theories provide a context within which to interpret my findings.

\section{Bourdieu}

Pierre Bourdieu's theories of the habitus (Bourdieu 1984) and the field (Bourdieu and Wacquant 1992) have been widely used to interrogate agency and structure within the field of museum studies. They feature in the work of Merriman (1989; 1991), Bennett 
(1995), Fyfe (2000) and Prior (2002), and have been celebrated for the 'light' they throw on 'the contradictory dynamics of the museum' (Bennett 1995, 11).

The relevance of Bourdieu's work to my thesis lies in its potential to explore the subjective perceptions (or habitus) of private collectors in relation to the heritage sector as an objective structure (a field). The habitus may be conceived of as a 'socialized subjectivity', which 'implies knowing ones place but also a sense of the place of others' (Grenfell and Hardy 2007, 28-29). Translated to this study the habitus may be understood as the private collector's perception of themselves and their collecting activities in relation to the heritage sector. The field for the purposes of this thesis may be understood as the network of private and publicly funded heritage institutions and individuals that constitute the heritage sector. The exploration of the private collector's agency in relation to the heritage sector is made possible through examining the 'underlying logic which orders it' (Grenfell and Hardy 2007, 29). The review of existing literature showed that the logic which positions the private collector in relation to the heritage sector is founded on evaluative judgments regarding the collecting activities of private collectors. This thesis therefore interrogates the logic purported in the review from the private collector's perspective or habitus. It further considers the private collector's perspective in relation to the capital associated with the heritage sector as a field.

Capital comes in various forms: economic, cultural and symbolic. It serves as a mechanism to position an agent in relation to a field. In drawing on Bourdieu's theories of capital I specifically focus on cultural and symbolic capital. Cultural capital may be defined as 'a form of knowledge, an internalised code or a cognitive acquisition which equips the social agent with empathy towards, appreciation for or competence in deciphering cultural relations and cultural artefacts' (Johnson in Bourdieu 1993, 7). Symbolic capital, in contrast, may be understood as the 'degree of accumulated prestige, celebrity, consecration or honour and is founded on a dialectic of knowledge (connaissance) and recognition (reconnaissance)' (Johnson in Bourdieu 1993, 7). A consideration of both forms of capital can be used to interrogate the agency of the private collector in relation to the heritage sector. 
Bourdieu's work must however be taken in context. It was published in France between the 1960s and early 1990s, and has been criticized for 'emphasizing class distinctions to the exclusion of other explanatory factors' (Merriman 1989, 163). Eager to ensure that my analysis of findings extended beyond a hierarchical positioning of the private collector and the heritage sector I sought additional theoretical frameworks that could inform my analysis.

\section{Actor-Network Theory}

The relevance of actor-network theory to the field of museum studies can be seen in Byrne, Clarke, Harrison and Torrences' 2011 book Unpacking the Collection: Networks of Material and Social Agency in the Museum (Byrne et al. 2011). Its benefit according to these authors is the ability to 'flatten' hierarchies so that all collecting practices may be 'seen as equally important' (Byrne et al 2011, 8).

The benefit of actor-network theory to my analysis of findings is twofold. First it eradicates a hierarchical positioning of agents. It does so by acknowledging that while society can be stratified into larger societal structures (macro agents) and individuals (micro agents), that such stratification is insufficient in determining an entity's agency. 'The macro', according to leading actor network theorist Bruno Latour, 'is neither 'above' nor 'below' the interactions, but added to them as another of their connections, feeding them and feeding off of them' (Latour 2005, 177). This offers the possibility of considering the heritage sector's influence on the perceptions and practices of private collectors, whilst acknowledging the equivalent status of each agent.

Secondly, it accommodates an analysis of the private collector's agency through acknowledging it is a combination of people and things that constitute an agent. Actor-network theory is a "way of suggesting that society, organizations, agents and machines are all effects generated in patterned networks of diverse (not simply human) materials' (Law 1992, 2). This offers the possibility of considering the private collector's agency through an analysis of their relationships to other human agents and the objects they collect. 


\section{Stebbins}

Robert Stebbins's concept of the social world and its associated ethos also has much to offer the theoretical framing of my research. Stebbins uses the concept of the social world to explore networks associated with 'serious leisure' participants.

Serious leisure is the systematic pursuit of an amateur, hobbyist, or volunteer core activity that people find so substantial, interesting, and fulfilling that, in the typical case, they launch themselves on a (leisure) career centered on acquiring and expressing a combination of its special skills, knowledge and experience (Stebbins 2010, 20).

In exploring the topic of serious leisure and its participants, Stebbins engages with their social world: 'a complex mosaic of groups, events, networks, organizations, and social relationships' (Stebbins 2001, 54). He observes that the social world of serious leisure participants 'is often further comprised of a public (fans, audience, spectators)' (Stebbins 2001, 54). The appeal of Stebbins's concept of the social world to this research is its ability to explore how the private collector's relationship to the public they serve also shapes their agency. The exploration of this relationship is further enhanced through a consideration of their shared values, as encapsulated in Stebbins recognition that the social world is further comprised of a 'unique ethos'. Stebbins defines this concept as 'the spirit of the community... as manifested in shared attitudes, practices, values, beliefs, goals and so on' (Stebbins 2007, 12). The concept of a shared ethos also offers further analytical possibilities when examining the values of the private collector in relation to those of the heritage sector.

\section{Summary}

The concepts of agency described by Bourdieu, actor-network theorists and Stebbins provide valuable socio-philosophical paradigms in which to interpret my findings. They accommodate an analysis of the private collector's agency through a consideration of their subjective tastes, practices and values in relation to other societal structures, people and objects in their environment. Such an analysis provides a deeper understanding of the private collector's agency that can be used to position them in relation to the heritage sector in accordance with my research aim. 


\section{Research design}

The preceding sections have shown how the literature reviewed informed my aim, research questions and interpretation of findings. This section details how my research was carried out. In-depth audio-visual interviews were conducted to provide information relevant to all four research questions. Visual data obtained during the course of these interviews provided observational information that was used to analyse the collecting practices of private collectors and test the validity of verbal data captured. This data was analysed using the constant comparative method, and findings were related to broader sociological perspectives as well as existing literature that addressed the values and best practice collection management standards of the heritage sector. The rest of this section offers greater detail regarding my research design. It is broken into the following thematic concerns: methods, research population, sampling, participants, data collection, interpretation of empirical material, archiving, credibility, limitations and approach to writing up.

\section{Methods}

The exploratory nature of Susan Pearce's theories regarding 'Collecting Studies' heavily influenced my methodological approach (Pearce 2004). Its focus on the perspectives of others as meaningful was well suited to my research aim and complemented the approaches of Marie Stig Sørenson (2009) and Sarah Pink (2004) whose concepts also informed my methodology.

In reflecting on research into collecting, Pearce observed that while 'collection study has been the subject of intense effort over at least three centuries, to go back no further, collecting has been considered worth studying only in the last decade at the very most' (Pearce 2004, 49). This compelled Pearce to distinguish between the traditional mode of enquiry she termed 'Collection Studies' and the more recent mode that she termed 'Collecting Studies'. Collection studies, Pearce argues, are 'assumptive' and 'authoritarian' (Pearce 2004, 49). Motivated by the desire 'to learn more' about the nature of the world, man and the past, these studies, Pearce asserts, often result in works that are 'descriptive' and 'impersonal' (Pearce 2004, 50). In contrast Pearce considers Collecting Studies to be 'reflexive' and 'exploratory', as they concern the 'personal' to focus on 'social practice' and the 'construction of 
identity' to 'discover why and how ideas about the world, humans, the past, are made' (Pearce 2004, 50). The Collecting Studies approach complements the aim of my research to focus on the perspectives and collecting practices of private collectors as a means to better understand their position in relation to the heritage sector.

The recognition that the context of interviews is as significant as their content provided the impetus for the method of interviewing to be used in conjunction with the method of observation (Stig Sørenson 2009). The method of interviewing has been credited for its ability to 'engage with complex and abstract ideas, such as heritage, in an enlightening and constructive manner rather than one that produces closure' (Stig Sørenson 2009, 166). Given this research was intended to explore the values and practices of the private collector, rather than presuppose what these values and practices are, the method of in depth, open-ended interviewing aligned well with the research aim.

The method of observation was employed for two reasons: firstly, it served as a resource to analyse the collecting practices (storage, exhibition) of the private collector. This enhanced my ability to situate the private collector in relation to the heritage sector based on how these practices mirror or differ from institutional collecting practices. Secondly it provided a means of observational analysis to study participants' nonverbal language - 'movement or body language that indicates a person's state of mind during an interaction' (Rosenstein and Israel 2002, 23).

Audio-visual recording was chosen as the primary vehicle for data collection because it facilitated both research methods (interviewing and observation) concurrently. Sarah Pink highlights some of the benefits of audio-visual recording below:

The significance of video in the interview process is threefold. First it provides informants with a platform from which to speak authoritatively, giving their subjectivity a voice. Second, by focusing on the visual and material environment the video interview is a form of visual / material elicitation that might evoke "deeper" accounts and memories. Third video gives informants an opportunity to show and display the visual/material symbols of self-identity 
that represent personal trajectories and ambitions and form part of the constitution of self (Pink 2004, 70).

In addition to these benefits the use of video allowed me to observe fine points of detail (such as body language), and assisted in the consideration of 'the local ecology of objects' to study relationships between objects in situ and the topic under study (Heath et al. 2010, 6-7). The ability to view 'raw' data repeatedly also allowed for the exploration of multiple views and multiple perspectives (Erickson 2011).

\section{Research population}

Private collectors form a part of the public that heritage sector professionals are ethically obligated to serve (International Council of Museums 2009). They are distinguished from heritage sector professionals on the basis they independently fund their own collecting activities (International Council of Museums 2009). Previous studies provide evidence that private collectors are as varied as the society in which they live (Digger in Pearce 1998; Pearce 1998; Shuker 2004).

Statistical data collated by Jo Digger from participating collectors, in the previously described The People's Shows, reveals that there is no one collector archetype that can be neatly defined (Digger in Pearce 1998). This supports the claim that collectors are 'simply proportionately representative of the population as a whole...not a separate case with personal or social defining characteristics' (Pearce 1998, 46). Although Digger's and Pearce's claims stem from British studies conducted in the 1990s, the findings are congruent with Roy Shuker's (2004) investigation of sixty-seven New Zealand and international record collectors. The data suggest that, irrespective of location and the types of material collected, collectors are as varied as the society in which they live. These findings show that the private collectors who form my research sample are members of a broader population, characterized by its heterogeneity. This is corroborated by internet search results for private collectors in New Zealand, which reveal that there is no one collecting archetype.

Despite the general acceptance that there is no one collecting archetype, Russell Belk observes there are gender and socio-economic characteristics that influence what the 
private collector collects (Belk 1995). Belk states:

Based on the non-representative set of collectors I have interviewed men are more likely to collect guns...automobiles...stamps, antiques, books, tattoos, beer cans... wines, and sports items, while woman are more likely than men to collect jewellery, housewares (e.g. dishes, silverware), and animal replicas (Belk 1995, 99).

He further observes:

Because collections consist of non-functional objects or objects taken out of use, they remain a luxury even in an affluent society. And generally speaking the most widely revered areas of collecting are those that are the most expensive to pursue, just as the most revered collections in any area generally consist of the most costly pieces (Belk 1995, 99).

An internet search for adult collectors in New Zealand who make their collections publicly accessible can neither confirm nor refute such hypotheses. Nonetheless, the awareness of such bias provided the impetus to sample both men and women, from varying socio-economic backgrounds, to maximise the sampling heterogeneity.

Online searching also disclosed that there are a myriad of clubs and forums that cater to national and international collectors. Some private collectors choose to publicise their collecting activities on tourism websites. ${ }^{3}$ Others opt to participate in heritage sector outreach initiatives, such as the New Zealand Museums website established by National Services Te Paerangi. ${ }^{4}$

The relationship between private collectors and the heritage sector is also reflected on websites for various cultural heritage repositories, suggesting private collectors may have enduring relationships with heritage institutions. This assertion is supported by recent collaborative efforts between private collectors and cultural heritage

\footnotetext{
${ }^{3}$ http://www.tourism.net.nz/listings/nztg/attractions-and-activities/museums-and-artgalleries/ museums/ (New Zealand Tourism Guide 2010).

${ }^{4}$ http://www.nzmuseums.co.nz/esearch/account/all (National Services Te Paerangi 2010).
} 
institutions such as the Wellington City Gallery's Crown Lynn: Crockery of Distinction 29 January-25 April 2011, and The Adam Art Gallery 's Behind Closed Doors: New Zealand Art from Private Collections in Wellington, 4 June-18 December 2011. This suggests that heritage sector professionals are a potentially valuable resource in identifying private collectors who share their collections publicly.

A key criterion for private collectors to participate in this study was that they display their collections publicly. Private collectors share their collections publicly in a variety ways: online; physical sites / structures (in their own homes, purpose built private museums); loaning of collection items / collections to other heritage institutions; and exhibitions at collecting fairs.

\section{Sampling}

Because no reliable source was available to define and randomly sample the population of private collectors who share their collections publicly in New Zealand, Purposive Sampling was chosen as the best means of selecting a sample from my research population (Faugier and Sargeant 1997). Also known as Non-Probability Sampling or Qualitative Sampling, this method is used to select cases the researcher can learn the most from; with samples being typically small, they focus on the depth of information offered by research participants (Teddlie and Yu 2007).

In addition to purposive sampling, this study combined the principles of Snowball and Maximum Variation Sampling, with participants being selected based on the criteria that they independently fund their own collecting activities and that they make their collections publicly accessible. Snowball Sampling was used to identify private collectors via tourism and New Zealand Museum websites, a general appeal for volunteers on collectors' forums, and emails to cultural heritage professionals who have collaborated with private collectors. ${ }^{5}$

In light of Susan Pearce's schematic diagrams about value (Pearce 1998), and the centrality of this theme to the thesis, an effort was made to represent private collectors who collect a diverse range of material, with a minimum of two collectors from each

\footnotetext{
5 'In its simplest formulation snowball sampling consists of identifying respondents who are then used to refer researchers on to other respondents' (Miller and Brewer 2003b, 275).
} 
quadrant forming part of the research sample. These quadrants equate to the following four groups as described by Pearce:

Group 1 - 'fine art collectors / 'high' applied art /'fine' natural specimens'; Group 2 - 'archaeological material / anthropological material / most historical material / 'ordinary' natural history'; Group 3 - 'mass produced 'genuine' commodities turned into collection e.g. tea towels, egg cups, milk bottles'; Group 4 - giftware / tourist ware / unpleasant taxidermy/ pornography / kitsch: material collected sincerely / camp: the same kitsch collected ironically (Pearce 1998, 41).

Two participants from each quadrant were selected in an attempt to adhere to the criteria for Maximum Variation Sampling, which:

aims at capturing and describing the central themes or principal outcomes that cut across a great deal of participant or program variation. For small samples a great deal of heterogeneity can be a problem because individual cases are so different from each other. The maximum variation sampling strategy turns that apparent weakness into a strength by applying the following logic: Any common patterns that emerge from great variation are of particular interest and value in capturing the core experiences and central, shared aspects or impacts of a program (Patton 1990, 172).

My research sample consisted of eight collectors. This small sample size was in keeping with the nature of qualitative data, which recognizes the usefulness of studying small samples (Miller and Brewer 2003).

\section{Participants}

Informed by Susan Pearce's four-quadrant classification of value (Figure 1) my participants were selected to ensure that each quadrant had a minimum of two representatives. As collectors of fine art, Jim Barr and Fiona Campbell are situated in the first quadrant. Quadrant two includes Jean Hall, who collects textiles, and Ian Ladds, a collector of natural history specimens. Quadrant three - mass-produced 
materials - is represented by Alison Reid and Peter Smith. Alison Reid collects crockery - specifically Crown Lynn ceramics - as does Peter Smith, who also collects glassware and other mass-produced paraphernalia. John McCosh's taxidermy spans Pearce's fourth quadrant, with their natural history properties also positioning him in quadrant two. Bruce Lyon's diverse collection of police-related objects includes social history materials (quadrant two), mass-produced materials (quadrant three) and kitschy items (quadrant four),

These collectors were also selected because they represent the diverse ways in which collections are made publicly accessible. Alison Reid and Jim Barr loan and deposit their collection items into heritage institutions. Bruce Lyon and Jean Hall exhibit their collections in specially designated rooms attached to their homes. John McCosh displays his collection in a purpose-built cabin and Fiona Campbell's collection is housed in a travelling exhibition truck trailer. Peter Smith and Ian Ladds both share their collections publicly in community spaces as active members of collecting clubs. These collectors reside in both rural and urban areas, and make their collections accessible in a range of geographical regions (Figure 3).

\begin{tabular}{|c|c|c|c|c|c|}
\hline Name & $\begin{array}{l}\text { Location of } \\
\text { Collector }\end{array}$ & Collection Type & $\begin{array}{c}\text { Corresponding } \\
\text { Quadrant }\end{array}$ & $\begin{array}{l}\text { Mode of Public } \\
\text { Accessibility }\end{array}$ & $\begin{array}{l}\text { Location of } \\
\text { Access }\end{array}$ \\
\hline Jim Barr & Wellington & Fine art & 1 & $\begin{array}{l}\text { Loans to public } \\
\text { galleries }\end{array}$ & $\begin{array}{l}\text { Nationwide, } \\
\text { New Zealand }\end{array}$ \\
\hline $\begin{array}{c}\text { Fiona } \\
\text { Campbell }\end{array}$ & Wanaka & Fine art & 1 & $\begin{array}{l}\text { Purpose built site / } \\
\text { Truck trailer }\end{array}$ & $\begin{array}{l}\text { Nationwide, } \\
\text { New Zealand }\end{array}$ \\
\hline Ian Ladds & Nelson & $\begin{array}{c}\text { Natural history / } \\
\text { Mineralogy; palaeontology }\end{array}$ & 2 & $\begin{array}{c}\text { Collecting fairs / } \\
\text { Collecting club days }\end{array}$ & Nelson \\
\hline Jean Hall & Geraldine & $\begin{array}{l}\text { Social history / Lace; } \\
\text { textiles }\end{array}$ & 2 & $\begin{array}{l}\text { Museum attached to } \\
\text { home }\end{array}$ & Geraldine \\
\hline Peter Smith & Wellington & $\begin{array}{l}\text { Mass produced artefacts / } \\
\text { crockery; glass ware }\end{array}$ & 3 & $\begin{array}{c}\text { Collecting fairs / } \\
\text { Collecting club days }\end{array}$ & Wellington \\
\hline $\begin{array}{l}\text { Alison } \\
\text { Reid }\end{array}$ & Auckland & $\begin{array}{l}\text { Mass produced artefacts / } \\
\text { Crown Lynn crockery }\end{array}$ & 3 & $\begin{array}{l}\text { Loans to public } \\
\text { galleries }\end{array}$ & $\begin{array}{l}\text { Wellington; } \\
\text { Auckland }\end{array}$ \\
\hline $\begin{array}{l}\text { John } \\
\text { McCosh }\end{array}$ & Featherston & $\begin{array}{c}\text { Natural history / Taxidermy; } \\
\text { rocks }\end{array}$ & 4,2 & $\begin{array}{l}\text { Purpose built site / } \\
\text { Log cabin }\end{array}$ & Featherston \\
\hline $\begin{array}{l}\text { Bruce } \\
\text { Lyon }\end{array}$ & Dannevirke & $\begin{array}{l}\text { Social history / Police } \\
\text { memorabilia; vehicles }\end{array}$ & $4,3,2$ & $\begin{array}{l}\text { Museum attached to } \\
\text { home }\end{array}$ & Dannevirke \\
\hline
\end{tabular}

Figure 3. Distinguishing features of contributing participants. 


\section{Data collection}

Once private collectors were sampled from the research population, preliminary discussions were held with each one by telephone. These conversations explained the purpose of the project, the thematic concerns of the interview, the future of the footage captured and explored any concerns potential participants wished to address. An Information Sheet, Consent Form and Oral History Recording Agreement (see Appendices A-C) were issued to each participant prior to interviewing. ${ }^{6}$ The interviews adhered to the Victoria University of Wellington Code of Human Ethics (2003), and complied with the National Oral History Association of New Zealand Te Kete Kōrero-a-Waha o Te Motu (2005) Code of Ethical and Technical Practices (see Appendix D). Meeting these standards ensured ethical imperatives were fulfilled at both a University and national level.

After I obtained the informed consent of interviewees, and received signed copies of all three forms, audiovisual interviews were recorded at the location of the private collector's collection. ${ }^{7}$ The only exception to this rule was Fiona Campbell who was interviewed at the New Zealand Film Archive, because her collection was touring primary schools at the time of the interview. The decision to interview participants within familiar settings was influenced by a desire to reduce any anxieties the collector may have had about being interviewed. It also allowed an opportunity to film the private collector's collection in situ. The eight interviews were conducted between the 3 rd and the $28^{\text {th }}$ of October 2011. Interviews lasted between 45 and 90 minutes and were conducted at a mutually agreed time specified by the participants. The footage was filmed on Sony digital video high definition tapes, using a Canon XHA1 camera and an AKG C417 PP lapel microphone.

I combined the 'general interview guide approach' with a 'standardized open-ended approach' (Patton 1990). The standardized open-ended approach allowed me to pose

\footnotetext{
${ }^{6}$ The Oral History Recording Agreement used is approved by the National Oral History Association of New Zealand Te Kete Kōrero-a-Waha o Te Motu (NOHANZ) and was retrieved from the National Library of New Zealand Te Puna Mātauranga o Aotearoa website (National Library of New Zealand Te Puna Mātauranga o Aotearoa 2005).

${ }^{7}$ For consent to be informed it must be voluntary and occur without coercion or manipulation by the researcher, it involves the disclosure of relevant information whether or not researchers are asked for it and understanding of information by research participants (Wilkinson 2001, 16; Victoria University of Wellington Research Policy Group 2003).
} 
specifically written open-ended questions (see Appendix E for Interview guide), whilst the 'general interview guide approach' gave the flexibility to ask them in no particular order (Patton 1990). Questions were inserted into each interview as and when considered appropriate, with other questions emerging from the dialogue between the participant and myself. As my interest lay in exploring an activity that was personal to the participants, the freedom to explore information as it was proffered was important so that I could engage with emerging issues. The provision of an examinable instrument for inspection by decision makers and users also added legitimacy to my findings, embracing the ethical imperative of transparency (Patton 1990).

The focus of each interview was the collecting activities of the private collector (experience/behaviour and knowledge questions), with particular emphasis paid to how they conceive of the activity of sharing their collections publicly (opinion/value questions) (Patton 1990). Each interview also included biographical questions, which provided valuable contextual information (Patton 1990).

The decision to employ the method of observation was informed by an awareness that 'the image can reveal what respondents cannot say in words, are not aware that they know and do not realize is of immense relevance to the project' (Felstead et al. 2004, 118). The purpose of this footage was to gather a visual resource of the collection that could be later analysed in relation to the verbal descriptions of collecting practices proffered by collectors and be lodged as a permanent record in an archive.

Thorough notes were made immediately following the period of interviewing and observation. These notes recorded my experience and any ambiguities or issues that may have arisen from the data collation. This was considered to be 'critical to the rigor and validity of qualitative inquiry' (Patton 1990). Areas of ambiguity that required further clarification were followed up with emails to participants.

The tape served as the preservation master and footage was transferred to a digital hard drive. I used footage stored on the hard drive for the purposes of transcription and analysis. The qualitative data gathered was transcribed in full, with additional notes made from the visual material regarding storage and exhibition methods. A 
DVD copy of the interview and a transcript of its contents were sent to individual participants, prior to analysis to ensure any amendments or retractions they wished to make could be recorded and respected. None of the participants required any amendment or retraction of the contents of their interviews. A number of the participants corrected the spelling of individual names and technical terms in their transcripts.

\section{Interpretation of empirical material}

Interview and observation data was analyzed using the 'Constant Comparative Method', applying 'look / feel alike' criterion to unitize responses based on words or themes that frequently appeared (Maykut and Morehouse 1994, 126). In accordance with the 'Constant Comparative Method' provisional categories were created based on the common themes, with rules of inclusion for these categories being created as propositional statements (Maykut and Morehouse 1994). Additional consideration was given to those responses that were not covered by provisional categories with all findings being considered in relation to all other data sources (all interviews and all observations) as well as existing academic theory.

\section{Archiving}

Members of the public are able to access these interviews at The New Zealand Film Archive. The provision of public access to these materials is warranted on the basis that informed consent has been provided, that it is in keeping with the wishes of the participants, and that it promotes principles of transparency. According to Julie McLeod and Rachel Thomson 'the richness and value of qualitative studies is not exhausted or fully captured in one reading or telling, or in one time' (McLeod and Thomson 2009, 125). They advocate the archiving of qualitative data on the basis that 'research artifacts can be reframed as providing a lens onto another historical period, and the questions and puzzles that animated researchers working then. They can also become sources for subsequent study and re-use by others' (McLeod and Thomson $2009,125)$. It is hoped by archiving this footage that this material will provide further insights and understanding. 


\section{Credibility}

The credibility of this research was addressed by its adherence to the principle of transparency and its use of multiple methods.

Uwe Flick states that the reliability of data can be related to procedural conception, 'making the production of the data more transparent' (Flick 2007, 16). Aside from the procedures of gaining informed consent, and circulating transcripts and DVDs to individual research participants prior to analysis, stored video promoted principles of transparency through its flexibility to view 'raw' data repeatedly (Heath et al. 2010). The ability to view and review data allowed me to assess my interviewing techniques, explore bias and test the accuracy of my conclusions.

The use of multiple-methods also enhanced the credibility of this study (Patton 1999). It facilitated the ability to generate both verbal and visual data that could be compared. This was achieved through considering verbal responses of participants to interview questions in relation to observational data captured during the interviews, thereby allowing me to test the consistency of data captured (Patton 1999).

\section{Limitations}

This study was not without its limitations. My sample was small - eight people - and reflected the views of a specific group of people - private collectors who share their collections publicly - in a specific location - New Zealand - at a particular time 2011. This small sample size is compatible with the principles that underlie qualitative research (Teddlie and Yu 2007). Participants were chosen for their diverse characteristics and were selected in the context that any commonalities that were identified in such a diverse group could offer a deeper insight into the perspectives of private collectors who shared their collections publicly (Patton 1990). This insight was intended to be exploratory so the findings do not presume to be definitive, nor do they aim to represent the perspectives of all private collectors who share their collections publicly.

The medium I used to capture my data may also be seen as a limiting factor. Sceptics of video cameras used in research worry about the influence this medium has on the content captured. They hypothesise that this media makes people more self-conscious 
and therefore suggest it is likely to alter their behaviour (Hancock et al. 2009). While two collectors did express a feeling of nervous tension prior to their interviews, both subsequently affirmed that they enjoyed the process and were pleased they had participated. The other participants in my study had all been filmed in one way or another prior to me interviewing them; their comfort with cameras was evident in the ease with which they spoke. The frankness captured in all of my participants' responses suggested to me that the use of a video camera did not inhibit their responses. Further countering the alleged limitation of this method is an appreciation that in other ways it provided an advantage. Given that the majority of private collectors with whom I spoke were eager to tour me through their collections and speak to the objects in their environment, the ability to capture this footage provided a deeper understanding of their responses to scripted questions, and brought about new themes that would otherwise not have arisen had I not filmed them in proximity to their collections.

The archiving of this data might also be seen as an additional limitation, causing critics to suggest that the responses of private collectors would be altered in the knowledge they were being recorded for others to see (Barbour 2008). Given that I did not personally know the private collectors prior to these interviews, I am unable to guarantee that their responses were not shaped by the knowledge their interviews would be archived. That said I believe that the perspectives proffered are just as valid, as the projected self is a reflection of the self. The knowledge that the material would be archived was in other ways an advantage. A number of participants expressed their willingness to participate because of the educational benefits this archived material could offer others. The archiving of my data also complements my methodological choice. Aware that my findings cannot be definitive, the archiving of this data assists the exploratory nature of this research through providing a resource for other researchers to engage with.

\section{Approach to writing up}

Central to both the aim and methodological approach of this research is the private collector's perspective. The presentation of my findings has attempted to retain the 'voice' of the private collectors with whom I spoke. This was achieved through 
reproducing verbatim quotes captured in audio-visual interviews with each of the collectors. Although quotes have been edited and punctuated for ease of reading, the message is recorded faithfully. ${ }^{8}$ Frame-grabs and imagery have been selectively used to provide a deeper context to the perspectives of private collectors as and where appropriate. Every effort has been made to include comprehensive perspectives from all eight collectors.

\section{Summary}

This chapter has presented background literature that has framed my research and analysis of findings. It has shown that my research contributes to the field of museum studies and seeks to fill a gap in existing literature. Details pertaining to my research design were also provided. They explained that I used audio-visual interviews to capture verbal and visual data pertinent to my research questions and aim. The findings of this data are presented in the next two chapters.

\footnotetext{
${ }^{8}$ The quotes from collectors reproduced in this thesis are from the audio-visual interviews unless otherwise referenced.
} 


\section{Chapter Two: The social world of the private collector}

It's just a social group of people.

(Jim Barr)

The complex and multi-faceted relationship between the private collector and publicly funded heritage institutions within the heritage sector was discussed in the literature review. This chapter explores the relationship of the private collector to the heritage sector from the private collector's perspective. In doing so it draws on data that addresses the social world of the private collector and its associated ethos to present findings to the following research questions: How do private collectors perceive of the heritage sector and their relationship to it? What values motivate private collectors to share their collections publicly?

It begins with biographical sketches of each of the private collectors to elucidate their social worlds. This is followed by a closer examination of the private collectors' subjective opinions regarding the heritage sector and their relationship to it. It highlights the distinctions private collectors make between their tastes and practices and those of public heritage institutions within the heritage sector. These distinctions are explored in the context of their agency as audience members, collaborators and non-professionals.

The values that motivate private collectors to share their collections publicly are then discussed. This discussion seeks to explore the ethos of the private collector. It identifies the personal values that motivate private collectors to provide public access to their collections. These values are further examined in relation to the values of protagonists that inhabit their social worlds, the public they serve and public heritage institutions within the heritage sector. 


\section{Biographical sketches of each participant}

The following biographical sketches highlight the range of lifestyles, situations and approaches represented in my sample of collectors. In doing so they offer a context for the private collector and their social world. They introduce each collector in the order in which they were interviewed and are accompanied by a frame grab, which provides a visual reference to the participants as they appeared within the interview environment.

\section{Jim Barr}

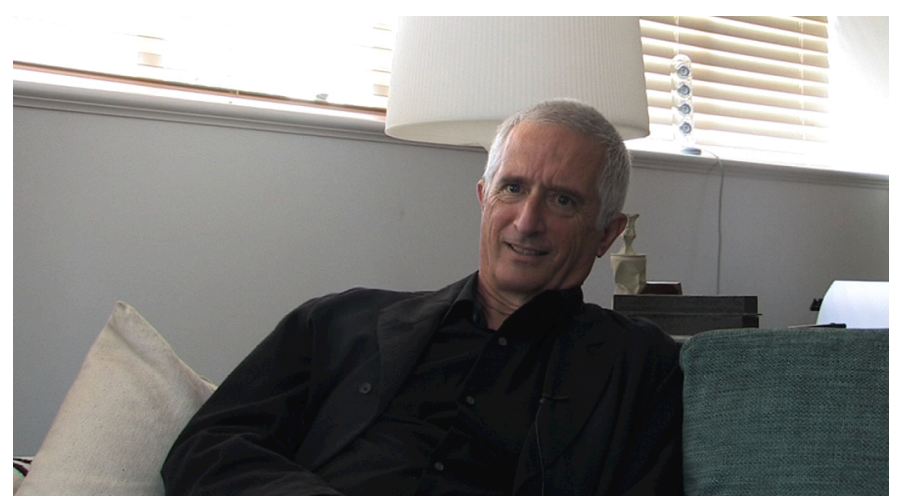

Figure 4. Jim Barr. Frame-grab taken from interview footage captured at Jim Barr's Wellington apartment, 03 October 2011.

Jim Barr has collected art with his wife Mary since they met at art school in the nineteen-seventies. Their collection focuses on contemporary experimental artworks produced by artists in their late twenties to mid thirties. They purchase ten or so artworks a year. Their collection embraces approximately 'four hundred and fifty works' and is housed in various locations. A 'hundred and thirty five' are stored at the Dunedin Public Art Gallery, while another 'fifty or so' works live in their apartment. The remainder are housed in an 'arbitrary opening gallery' they own in Wellington. Their gallery, On the Table, was established in November 2009 in response to a perceived lack of art galleries that showed the types of work they collect. They 'closed shop' after this niche was filled by a small number of artist run galleries in 2010. The space however lives on as a storage facility for their collection. Advocates of the dealer gallery system, they have strong relationships with art dealers, artists and curators. They frequently loan their works to galleries for public display, and have also gifted works to galleries, loaned works to friends and sold works. Viewing the 
work that they buy 'as a partnership with the artist', they give half the profit of any sale of a work back to the artist. Jim began his career in publishing and was Director of the Dowse Art Gallery for five years. He now works 'in the corporate sector...standing between creative people and business people as [a] sort of intermediary'. He publishes an art blog with Mary entitled 'Over the Net and Under the Table'.

\section{Fiona Campbell}

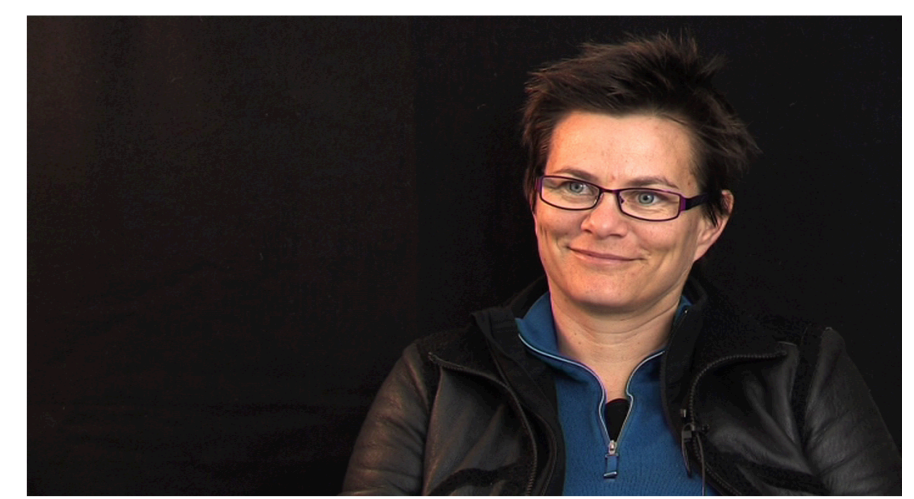

Figure 5. Fiona Campbell. Frame-grab taken from interview footage captured at the New Zealand Film Archive Wellington premises, 05 October 2011.

Fiona Campbell is the owner and director of The Real Art Roadshow - a travelling art collection that tours by truck to primary and secondary schools nationwide. The Real Art Roadshow was initiated after Fiona and her former husband become the benefactors of a significant financial windfall. Motivated to see the proceeds contribute to society in a meaningful way, they chose to connect secondary school students who were geographically isolated from public galleries with 'good quality art'. Comprising 'a hundred and twenty-eight artworks', The Real Art Roadshow collection is divided into two collections: The Black Collection, which consists of painted and drawn artworks, and The Silver Collection, which includes diverse media such as photography and sculpture. It was originally designed to educate high school art students undertaking the National Certificate of Educational Achievement (NCEA). Subsequently the project has broadened its reach, to include secondary, primary and pre-school students along with members of the general public. Staffed by volunteers and accompanied with published resources, the project has been in operation for five years and aims to continue for another five. Fiona has previously worked in advertising, as 'a dealer's dogs body', and as an operator of a glass studio. 
She is presently a member of the board of directors at The Museum of New Zealand Te Papa Tongarewa and describes herself as 'an art enthusiast'. Fiona is based in Wanaka.

\section{John McCosh}

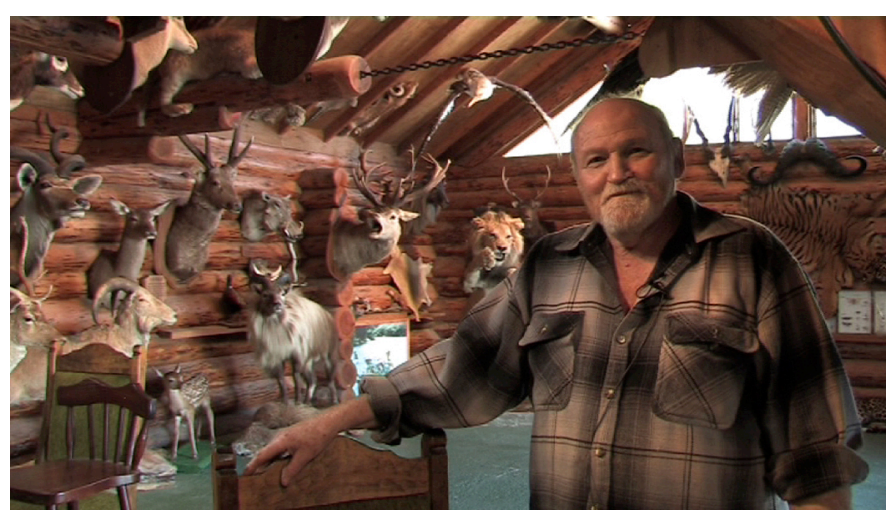

Figure 6. John McCosh. Frame-grab taken from interview footage captured at the Kahutara Taxidermy Gallery, Featherston, 07 October 2011.

Combining 'two hobbies...into a living', John McCosh runs the Kahutara Canoe and Taxidermy Gallery on his property in Featherston. Housed in a self-built log cabin an attraction in its own right - his collection of over three thousand taxidermied animals includes both his own work and the work of others who have donated their collections for him to exhibit. Donated collections include the Robertson Bird Collection, the Grey Rock Collection, a collection of horns from South Africa and an insect collection gifted to John by a boy from Martinborough School. John cites his first foray into taxidermy at the age of twelve, and credits his association with an older taxidermist for leading to taxidermy work on a commission basis. His work for the Wellington Zoo, enabled him to acquire several exotic animals, most notably 'Rusty the Lion' who John says is his 'biggest draw card'. John's canoe and taxidermy gallery business began with a chance visit from some American hunters, who expressed an interest in seeing his taxidermy specimens, then housed in his lounge. They inquired about other attractions in the area, and so John took them down the Wanganui River in his Canadian canoe. This experience prompted him to place an advertisement for guided canoe tours in the local paper, thus abandoning his career as a dairy farmer and starting his business as a canoe guide and gallery operator. Over the past thirty years bus tours, school groups, tourists and general members of the public have visited his gallery, paying a small admission charge for the privilege. 
John has now retired in the understanding that 'as long as [he is] healthy and fit [his collection] will always be open to the public'.

\section{Peter Smith}

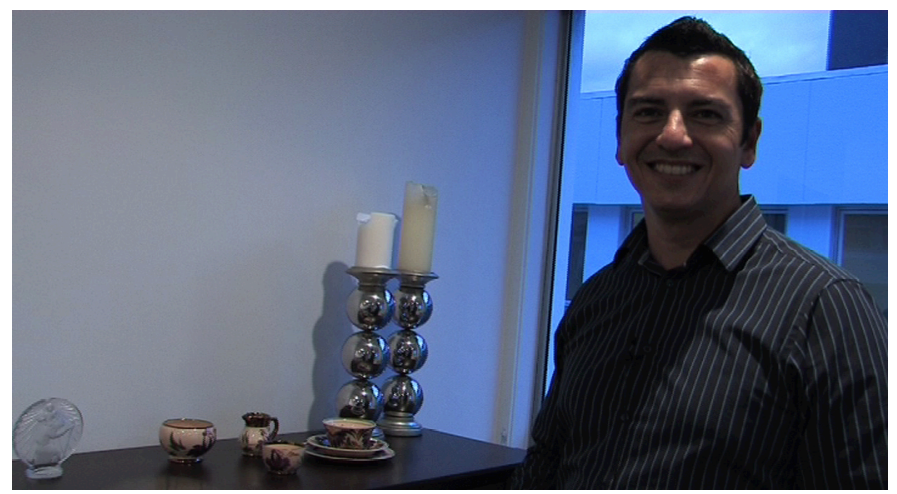

Figure 7. Peter Smith. Frame-grab taken from interview footage captured at Peter Smith's Wellington apartment, 14 October 2011.

Peter Smith is a member of the Wellington Antique and Bottle Club. His collection currently consists of Stuart Crystal ('sixty to seventy' pieces), Crown Lynn ('forty to fifty' pieces) and other mass-manufactured paraphernalia. Curtailing the precise number of collection items to the amount of storage he has at a given time, he cites his 'pet peeve' as 'people [that] have lined entire walls...with their collections'. Peter prefers to rotate collection materials around his apartment, and stores the majority of his collection in a storage locker. He says he has 'always been interested in collecting' and sees collecting as a means to further his own education: 'collecting is an education for me and if I can share it with other people and they can appreciate it, that's great'. Peter views the practice of display as an 'extension of collecting' and places great importance on communicating the 'context and the provenance' of the objects he collects to others. Peter first shared his collection publicly as part of a shopping-centre window display and now shares his collections publicly at collecting fairs. Working in banking technology since he was twenty, Peter who is now forty, dedicates much of his spare time to collecting. 
Alison Reid

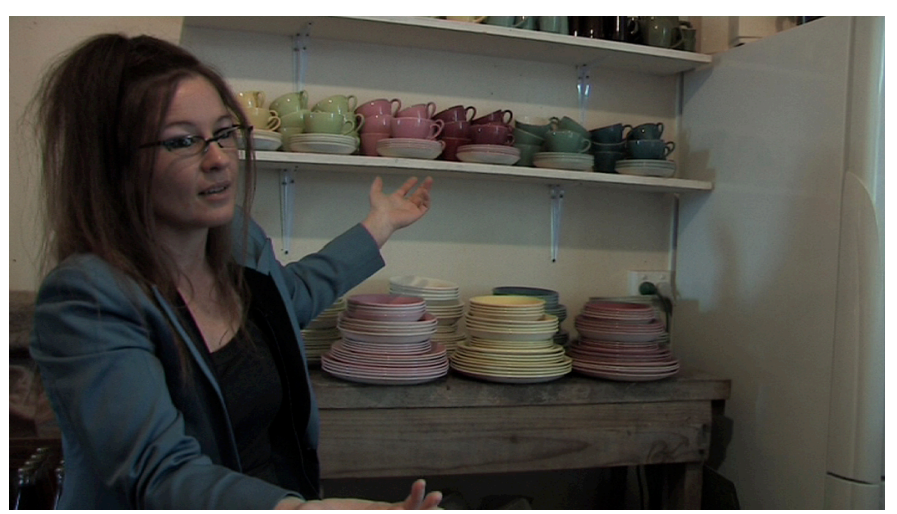

Figure 8. Alison Reid. Frame-grab taken from interview footage captured at Alison Reid's house, Auckland, 17 October 2011.

Alison Reid is a collector of Crown Lynn ceramics. She is specifically interested in the Colour Glaze dinner sets, of which there are twenty-seven. Her collection also includes items from the factory's Rattan, Fiesta and Replacement series, beehive bowls, ashtrays, teapots, and ornaments. Although Alison declared that she was 'heavily in denial about collecting' when she began to acquire Crown Lynn materials, she has considered herself as a collector since 2000. She established an Auckland based shop that specializes in 'Crown Lynn and vintage home wares, or kitchenalia' two years ago. Alison candidly stated that 'it wasn't until Abby Cunnane and Aaron Lister from Wellington City Gallery came into the shop that I actually knew I had a collection, to be honest'. This visit was responsible for Alison's participation in the 2011 Wellington City Gallery's Crown Lynn Crockery of Distinction exhibition, and its 2011-2012 follow-up show Crown Lynn: Pottery for the People at the Gus Fischer Gallery in Auckland. Alison has also deposited Crown Lynn items with The Museum of New Zealand Te Papa Tongarewa. Alison uses some of her collection items on a regular basis, and reserves others for display purposes, rotating collection items within her home as space permits. She has never counted the number of items in her collection, so its precise size is unknown. A cursory sighting of Alison's collection suggests that her collection items number more than a thousand. A former employee of the Auckland Theatre Company for fifteen years, Alison credits her experiences making tea for the company at community halls, as exposing her to the crockery that she now collects. 


\section{Ian Ladds}

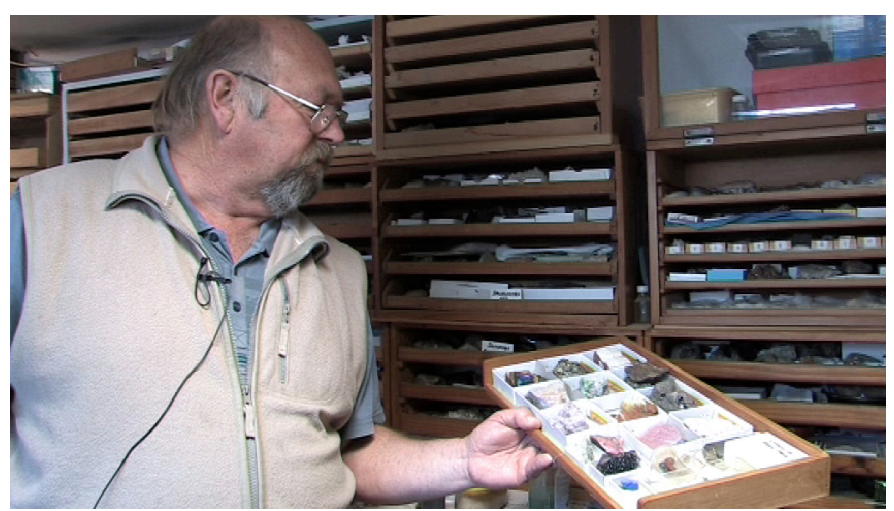

Figure 9. Ian Ladds. Frame-grab taken from interview footage captured in Ian Ladds's residential shed, Nelson, 21 October 2011.

Ian Ladds has been a member of the Nelson Rock and Mineral Club since the mid-tolate sixties. He actively collects palaeontology and mineralogy specimens and describes his current collecting activities as 'a hobby at the moment to try and make a...collection of stuff that local people can use for... a guideline'. The majority of Ian's collection items are a product of collecting club fieldtrips he undertakes in the Nelson region. Ian supplements this collection with a few bought specimens: 'I'm not a big fan of buying stuff but sometimes you just need it to help'. Ian exhibited collections publicly at local Agricultural and Pastoral Shows in his youth, and now continues to share his collections publicly at collecting fairs and community sites. Most recently Ian exhibited fossils, which he had collected from the Nelson Region, at the Tasman District Library with other club members. His willingness to share his collection extends to the gifting of specimens to other club members and GNS Science; a New Zealand earth, geoscience and isotope research and consultancy service. Unsure of the precise number of specimens in his collection, it would appear from scanning the shelves that the number of specimens is likely to be in excess of five thousand. Storing his collection in a residential shed, Ian houses specimens in wooden drawers; the majority of which he has built himself. Concerned by the damage that can be caused by excessive collecting from natural sites, he worries about the ethical imperatives associated with natural history collecting and the future of his collection. Ian has worked on and off over the years, predominantly as a driver. 


\section{Jean Hall}

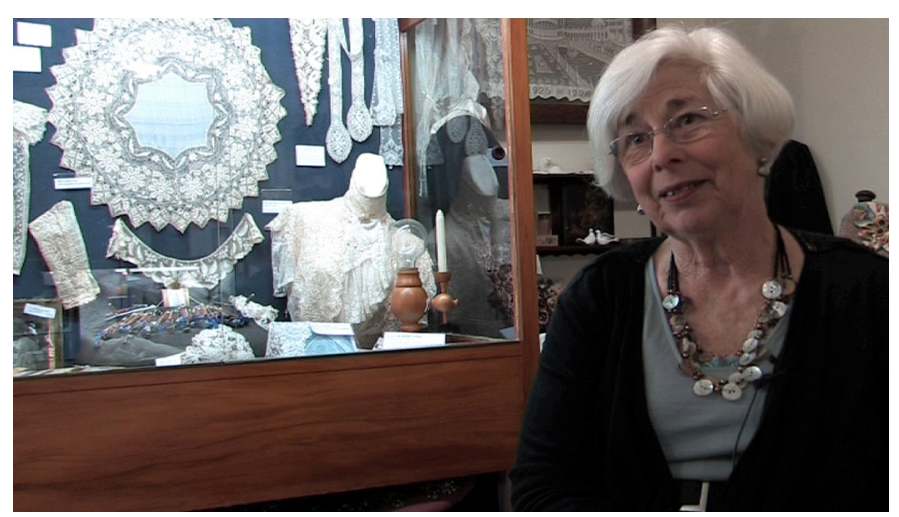

Figure 10. Jean Hall. Frame-grab taken from interview footage captured at Lillia's Lace Museum, Geraldine, 23 October 2011.

Jean Hall collects lace and textile exemplars and equipment associated with lace making, spinning, weaving, needlework and pattern design. Her collection of 'five hundred and fifty odd' items is made publicly accessible, for a small admission fee, at Lillia's Lace Museum. The museum consists of a structure attached to her home in Geraldine and was named after her grandmother Lillia Langridge, from whom her first lace sample was obtained. The collection consists of items that Jean has acquired from second hand shops and members of the community, as well as those she has produced herself, as a skilled lace maker. Materials are displayed in glass cabinets and framed on walls, they are categorised according to style and the geographic location to which the styles relate. Jean provides context to these items through written text and props. The museum was established originally on her property in the Nelson region, following prompting by fellow Lace Society members who expressed interest in accessing her collection. The collection was relocated to Geraldine in her retirement. Jean's work history includes bridal-wear, pattern, and fashion design in her hometown of Christchurch, as well as work on her Nelson farm. 


\section{Bruce Lyon}

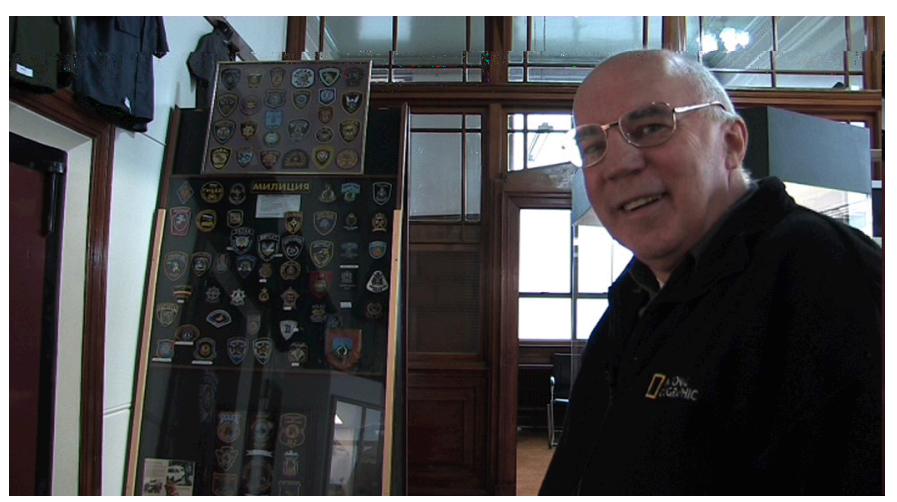

Figure 11. Bruce Lyon. Frame-grab taken from interview footage captured at The International Police Museum, Dannevirke, 28 October 2011.

Bruce Lyon collects police memorabilia and vehicles that relate to the former New Zealand Ministry of Transport, and New Zealand and International Police. Estimated by Bruce as containing five to ten thousand objects, the collection consists of a range of police-related items. These include soft toys, key rings, models, medals, patches, badges, uniforms, weapons, motorbikes, cars and ephemera. Collection items have been acquired from online auction sites, trading with other collectors and donations by acquaintances and members of the public. Open since July 2010, Bruce makes the collection publicly accessible at The International Police Museum for a small admission charge. The museum is situated on the ground floor of the former Public Trust building in Dannevirke. The second floor is occupied by Bruce and Maureen's home, and is also the site of their Bed and Breakfast business. A traffic officer for nineteen years, and a police officer for seven, Bruce retired to establish The International Police Museum and Lodge using part of his superannuation to purchase collection items. Bruce now works in security to subsidise the Museum. He says 'the fun part is making [my collection] available for other people to see so that they can understand and talk about [it]'.

These biographical sketches attempt to give an impression of the unique situations, characteristics, and persona of the collectors with whom I spoke. They reveal that the objects these collectors collect are associated with their former or current career, or the leisure interests they are devoted to. These introductions also convey a sense of the complex and diverse social world that each collector inhabits. Intimating that their collecting activities do not occur in isolation, they draw attention to the relationships 
these collectors have had and continue to have with colleagues, heritage sector institutions and professionals, collecting clubs and the public they seek to serve.

\section{Relationships between private collectors and heritage institutions}

The literature reviewed in Chapter One showed that in one sense, private collectors can be seen as members of the public that heritage institutions serve (International Council of Museums 2009) and in another they can be seen as a 'non-professional' (Stebbins 2007) collecting peer, whose collections constitute a resource for institutional display (Francis 1996). These different positions are indicative of dynamics found within a field.

The dynamics of the field, it is said, arise from the positions, dispositions and position taking of agents. That is to say, a field has structured positions, whose occupants typically have different resources and different dispositions. These resources and dispositions are partly brought from without the field - a matter of their generic capital holdings and habitus of origin. These features also alter in accordance with experience within the field itself. Agents orientate themselves towards the field, or take their positions, in light of their resources and dispositions (Warde 2004, 12).

The following section examines the various positions of the private collector as audience member, collaborator and amateur. It reproduces data from interviews with private collectors to explore their 'capacity to differentiate and appreciate' their 'practices and products (taste)' from heritage institutions within the heritage sector. (Bourdieu 1984, 170). In doing so it draws on Bourdieu's theory of the habitus, to discuss the cultural capital of the private collector and their perceptions regarding the symbolic capital of institutions within the heritage sector.

\section{The private collector as audience member}

In reflecting on their perceptions of the heritage sector as audience members, the private collectors with whom I spoke generally conveyed a sense of dissatisfaction. 
For both Jim Barr and Fiona Campbell, collectors of fine art, criticisms focussed on the display methods employed by publicly funded heritage institutions. Fiona Campbell remarked that she found 'public collections often quite dry', further commenting that: 'I've been in a lot of galleries and I was in one the other day and I thought "uh" this is so boring because it's a work there, and a work there, and it's all very polite, and there's not much going on'. Jim Barr described his disappointment with institutional display practices by stating: 'I think a lot of the work that we're interested in is very difficult for them to show and they often show it very very badly'. He further explained:

I think the art galleries really really struggle to show the sort of work that we're interested in, and more so now than before. You know the et al. installations I mean how many times can you actually show them.

Christchurch [Art Gallery] has bought a huge one but they might show it once every fifty years or something. The art hierarchy is still paintings on the wall if you're going to look at what's most likely to be seen. If you go to our City Gallery in Wellington that claims to be on the cutting edge of art, it basically shows paintings... and the institutions are still in that conservative position (Jim Barr).

Bruce Lyon, a collector of police related materials, was also critical of the display methods employed by heritage institutions. He described his frustration with institutional practices of interpretation, to relay his preference for the display of objects over text:

The modern style of museum is lots of words all over walls, much like graffiti but very few items. I'm not old school by any stretch but to me a museum is about displaying things. It would be like displaying Tutankhamen's tomb by putting up a photograph, and putting a piece of rock there, and saying this is part of it, no point at all. We want to see things and experience them and understand them because we're looking at the object not at lots of words about it (Bruce Lyon). 
Peter Smith and Alison Reid, collectors of mass-produced materials, lamented the absence of objects they relate to in institutional collections. In describing her experience visiting the Museum of New Zealand Te Papa Tongarewa, Alison Reid stated: 'It's hard cos I'll walk into Te Papa and go ooh...they haven't got this they haven't got that', complementing Peter Smith's observation that 'something institutions have struggled with is trying to find... collection.'

The collectors of natural history specimens, John McCosh and Ian Ladds, criticized heritage institutions for their inability to display all of their collection items. John McCosh did so by pointing to the disproportionate number of items in storage at The Museum of New Zealand Te Papa Tongarewa versus those on display: 'They reckon at Te Papa you know two thirds of the collection is downstairs'. Ian Ladds attributed the inability for heritage institutions to display all of their collection items to space limitations: 'it comes to that debate as to how [heritage institutions] don't have the space to do it'.

Like Ian Ladds, many of the collectors tempered their criticisms of heritage institutions by relaying the perceived constraints heritage institutions faced. Peter Smith believed the lack of collection materials in institutional collections was a historic oversight that today's institutions were actively addressing: 'I think that the institutions are changing and they're changing as quickly as they can but they just don't have the years of collecting behind them to... actually bring anything into it themselves'. Jim Barr, a former curator who had worked within institutions, relayed how institutional workflows undermined the work of curators:

I think the issue around institutions at the moment is that the relationship of the curators to the actual objects has been separated, by designers and conservators, and writers, and exhibition organizers. Where the curator used to physically hold the object and put it on the wall or place it, they don't do that now, and I think that physical relationship is a huge part of the display process (Jim Barr).

Such criticism of, and empathy for, institutional practices is indicative of a particular level of understanding on the private collector's behalf. A level of understanding that 
is synonymous with Pierre Bourdieu's concept of cultural capital. Cultural capital, as outlined in Chapter One, is a 'form of knowledge' that facilitates an individual's capacity to appreciate and interpret 'cultural relations and cultural artefacts' (Johnson in Bourdieu 1993, 7). Used here, the concept of cultural capital elucidates how the opinions expressed by the private collectors with whom I spoke are a product of their specialist knowledge as collectors of particular objects who share their collections publicly. This knowledge augments how they see the world, as articulated by Fiona Campbell in her statement: 'I can't just see a picture on the wall and go oh that's pretty... because I've spent too long looking, spent too much time reading, spent too much time watching audiences'.

The private collector's specialist knowledge causes them to focus on the display methods heritage institutions employ, or leads them to observe the absence of these objects in institutional collections. Private collectors distance themselves from heritage institutions within the heritage sector on the basis they see another way of doing things. This is indicative of the private collector's habitus, a product of their personal tastes and their activities as people who share their collections publicly. The habitus of the private collector not only explains why private collectors criticise publicly funded heritage institutions as they do but it also offers transformative possibilities.

The producers are led by the logic of competition with other producers and by the specific interests linked to their position in the field of production (and therefore by the habitus which have led them to that position) to produce distinct products, which meet the different cultural interests (Bourdieu 1984, 231).

The private collector and heritage institutions within the heritage sector are unified by their specific interests of collecting and display. The private collectors' subjective tastes however cause them to identify other ways in which the services of heritage institutions could be enacted. These tastes distinguish them from heritage institutions within the heritage sector and suggest that the activities with which they engage seek to offer something different from them. 


\section{The private collector as collaborator}

In a proactive attempt to address their dissatisfaction as audience members, two collectors, Alison Reid and Jim Barr, collaborate with heritage institutions. Alison Reid explained: 'All I can do instead of trying to judge them, is go I'm a Crown Lynn collector, I have some pieces, would you like some advice, am I able to donate anything to improve your collection'. This perspective also resonated with Jim Barr: 'We're very critical of the institutions but we're also very supportive of them too, we give them works and we've always been happy to lend'.

Despite his willingness to collaborate, Jim Barr is aware that private collectors are not always taken seriously.

My feeling really is [that] some of the very wealthy collectors get treated ok, but only socially. I don't think they're taken very seriously as people who are knowledgeable about art. I don't think they are taken seriously at all to be quite honest. That's changing of course because as the public galleries have become so incapable of collecting objects now, it's all going into private collections, so the strength of the private collector is growing (Jim Barr).

Jim Barr's statement reveals his perception that any recognition heritage institutions are likely to afford private collectors will most likely be predicated on the 'use' value of their collections. He sees this is a source of tension between private collectors and the heritage institutions.

The reason to be quite honest that galleries often have trouble borrowing from private collectors and from artists, is that the only time they ever show any interest in them is when they want to borrow something... [It's] just a way to generate their business (Jim Barr).

Further to this tension was Jim Barr's observation that heritage institutions can misrepresent the motives of private collectors who collaborate. In supporting this claim, Jim Barr reflected that the title of an institutional show, for which he had recently loaned works, directly contradicted his collecting philosophies: 
It was very interesting that Tina Barton called her show at the Adam [Art Gallery] 'Behind Closed Doors' which you know Mary and I thought was just a wacky title because we really spent a lot of time trying to make sure that our collection was available (Jim Barr).

Jim Barr's statements echo the exploitative nature of heritage institutions as described in criticisms about The People's Shows (Francis 1996).

The literature reviewed suggested that private collectors collaborate with public institutions because they wish to enhance their social status (Pearce 1998). It may be suggested then that the alleged elevation of status through collaboration is only possible if the private collector affords the heritage institution a high degree of status or symbolic capital. An examination of the symbolic capital that private collectors afford to the heritage sector revealed that this varied. For example Alison Reid believed that exhibiting her collections in galleries validated her collecting activities: 'I think...lending them to galleries qualifies what I'm doing, and so I think that qualified it with my mother who thought I was probably going a little bit crazy, [and] qualified it with my partner and his parents'. Jim Barr however stated that while the exhibition of artworks from private collections in heritage institutions may have historically added value to a collectors' artworks, such currency was no longer applicable:

I don't know whether actually sharing [the collection] adds value to it. In the old days, like in the seventies and eighties, the art market wasn't as mature as it is now, I think then something shown in a public art gallery was a sign that it had achieved a certain status and I don't think that's true anymore (Jim Barr).

Jim Barr described the way he was able to overcome the problem of unequal symbolic capital by reducing the macro agency of the heritage institution to the micro agency of its individual staff. Rationalising the symbolic capital of the heritage institution in this way the institution becomes a network of individuals with differing perspectives.

I mean these are people that we've known, and often people that you've known as younger people that have gone on and done things. We've got a very 
close relationship with Christchurch largely because of Justin Paton who was the curator at Dunedin [and] did two shows of our collection. Because we've been working with Michael Parekowhai on his Venice project we've seen more of Jenny Harper [Director of the Christchurch Art Gallery] who we knew earlier but didn't get on with, and now you know get on better with. I mean it's just a social group of people (Jim Barr).

Such a view is complementary to the way actor-network theorists see the world. As actor network theorist Bruno Latour articulates:

Macro no longer describes a wider or a larger site in which the micro would be embedded like some Russian Matryoshka doll, but another equally local, equally micro place, which is connected to many others through some medium transporting specific types of traces (Latour 2005, 176).

It is in this 'flattened' state that we can then look at the private collector side-by-side with the publicly funded heritage sector worker.

\section{The private collector as amateur?}

The views of private collectors consistently affirmed their recognition of professionals within the heritage sector. This finding challenges Stebbins (2007) assertion that collectors are hobbyists because they have no professional counterparts.

For example Jim Barr inferred that his work as a freelance curator ceased because galleries became professional organizations: '[I] freelance curated for about fifteen years but the work really stopped with the professionalization of the galleries'. Alison Reid and Fiona Campbell acknowledged the professional status of heritage sector staff by referring to the specialist skills. This was reflected in Alison Reid's feeling of inferiority relative to The Museum of New Zealand Te Papa Tongarewa curators she had dealt with as a depositor: 'Sometimes you feel slightly inferior because [the Te Papa curators] are so knowledgeable on art things '. Fiona Campbell advised that she drew on the specialist knowledge of a heritage sector professional because she felt unqualified to curate The Real Art Roadshow collection: 
For The Roadshow I knew I wasn't qualified myself to actually put the collection together so I got a couple of curators on board. I got Rob McLeod...who is a senior artist in New Zealand [and] has made painting his career, so he's not some hobbyist. He's got the intellectual rigor to actually help me put a collection together, plus he's taught for you know thirty five years, he taught art [and] knows what paintings are going to be able to speak to the students and bring something good and creative into their education. But I also got a guy called Gerald Barnett, he spent many years up at National Art Gallery when it was in Buckle Street and I met him when he was Director of the Mahara Gallery in Waikanae (Fiona Campbell).

The specialist skills to which Alison and Fiona refer define the professional museum worker in accordance with ICOM statutes (International Council of Museums Statutes, Article 2.2 in Boylan 2006, 423). ICOM's definition of a museum professional also identifies the need for professionals to adhere to the ICOM Code of Professional Ethics. This code further obligates the museum professional to share their knowledge with others (ICOM Code of Ethics for Museums para. 8.2. in Boylan 2006, 425). In a New Zealand context this ethical obligation is upheld by The Museum of New Zealand Te Papa Tongarewa's National Services Te Paerangi outreach service. Their mission is 'to strengthen the museum sector by providing practical and strategic help to museums, galleries and iwi throughout Aotearoa New Zealand' (Museum of New Zealand Te Papa Tongarewa 2012). Two of the collectors, Jean Hall and John McCosh, used their services. In describing the benefits of his association with this organization John McCosh said: ‘they're always offering advice and what have you...we had a visit from them oh about six months ago, they're very helpful'. Jean Hall explained that 'they send me information [on] workshops and things [and] if I'm interested I'll go. I have been to one or two, one in Nelson and one in Timaru'. When asked if the workshops had influenced her collecting practice Jean Hall stated 'not really', preferring to cite her collecting practices as a process of 'trial and error'.

Jim Barr however felt that heritage institutions had not 'made any effort whatsoever to put [their] knowledge out into the private sector'. This led me to wonder whether other private collectors who do not use the terms museum or gallery in their collection 
titles felt similarly. Currently these collectors fall outside the remit of National Services Te Paerangi's target audience for outreach.

The relationships Jean Hall and John McCosh have with National Services Te Paerangi and its staff, allow us to position their activities as those of Stebbins's amateur. According to Stebbins an amateur engages with specialized knowledge of a technique or skill that constitutes a professional role for some people, and has contact with a professional (Stebbins 1977). This said, it is important to note that none of the collectors I spoke to used the term amateur to identify themselves or their collecting activities. Instead the private collectors involved with this study used terms such as 'art enthusiast' (Fiona Campbell), 'intermediary' (Jim Barr), 'hobby' (Ian Ladds, Jean Hall), 'business' (John McCosh), 'collector' (Peter Smith and Alison Reid) and 'curator' (as printed on Bruce Lyon's business card).

What mattered to the private collectors with whom I spoke was not a neatly defined term that encompassed them and their activities, but rather their desire to relay the advantages of not being a heritage sector 'professional'. Choosing to highlight the advantages of her collecting activities occurring outside of a publicly funded heritage institution, while also communicating her relationship to one, Fiona Campbell said:

It's quite interesting cos I'm on the board of Te Papa and we always have that fight, it's like well we are suppose to collect, but we're also supposed to share and like any museum they really struggle to share much of their work. A.

Because of wall space. B. Because of conservation aspects. But given the Roadshow is my own personal collection, I mean it's The Roadshow Collection but I personally own it, I am personally responsible for it and I've personally made the sacrifice that work is going to travel for ten years and be looked at, and in some cases poked and prodded by students. It may be a bit tired at the end of it but it will have done its job, you know what's the bloody point of it if it doesn't, and I'm pretty sure the artists would agree that they'd rather have the work be semi-shabby at the end and well loved by thousands of people than packed away somewhere...The great thing with The Roadshow is we can make our own decisions we're not beholden to anyone but ourselves (Fiona Campbell). 
Jim Barr, who had been associated with the heritage sector as Director of The Dowse Art Gallery for five years, also described the advantages he had as an individual who collected outside of an institution:

I mean we are more casual with the work and I think that we see the work as living in the real world. We don't see the work as being frozen in time, which I think is sort of the institutional position. The institutional position is that you buy the work and then really your duty is to keep the work looking the same as that forever, whereas I believe that people make things and they come into the world and then they live in the world and if they get bumped and knocked, I mean one obviously doesn't intentionally damage anything, but if something is bumped that's just part of its life. I don't see it is then necessary to immediately fix it (Jim Barr).

A consistent factor that influenced these collectors' collecting practices was the perceived autonomy they had as individuals who collected outside of the heritage institution. The benefit that they associated with this autonomy was their ability to privilege the activity of display over that of preservation.

\section{Values that inform public display}

The last section observed that the private collectors with whom I spoke see themselves as distinct from heritage institutions and their workers. It showed that distinction is founded on their ability to differentiate their tastes and practices from those of institutions within the heritage sector. It also discussed the private collectors' perception that operating outside of heritage institutions allowed them to privilege the activity of display above that of preservation. This section examines the values that motivate private collectors to share their collections publicly. It considers the ethos of the private collector as manifested in the practice of display and the values they share with others. It begins by addressing the personal values that inform the private collectors' desire to share their collections with others. This is followed by an exploration of how the values of private collectors are shared with other protagonists in their social world, the public they serve and institutions within the heritage sector. 


\section{Commitment to objects}

For Jim Barr, the motivation to display collection items stems from a sense of personal responsibility he feels towards the objects in his collection. He expressed the sense of personal responsibility he felt by contrasting his attitudes with those of other private collectors.

I remember when I was [working] at the Dowse [Art Gallery], we got all the Wellington collectors together to talk about the whole idea of what your responsibility to the objects were as a collector. I remember just being so shocked that most people just thought there was no responsibility that they were objects. I remember one person said that she had a McCahon and if she wanted to chop it into pieces she'd do it, and it was nothing to do with anyone but herself. I think it was from that very extreme capitalist ownership idea through to very socialist ideas that you don't own these things at all, I mean we're somewhere in the middle of that I guess (Jim Barr).

Jim Barr sees the activity of display as an extension of the commitment he has to the objects and to the artists who made them. This is reflected in Jim Barr's attitude to loaning works to heritage institutions:

We're not prepared to lend work if [heritage institutions are] going to put up barriers and do things that are against the spirit of the work. Our final arbiter really is the artist who did the work, and if they've got any feelings at all about it we'll put ourselves behind that (Jim Barr).

Alison Reid also expressed her commitment to the items she collects and to their manufacturers: 'I made the choice to for my own purposes as well to research Crown Lynn and find out historically how important this company was to our history which is hugely important'. She viewed the activity of public display as a means to expose others to these objects she found so significant: 'a philosophy of mine is in building this jigsaw eventually I'd like everybody to see it'. This perspective was consistent Peter Smith's: 'When you actually display publicly and stand behind your collections you're raising things to prominence that perhaps haven't had a historical value'. 


\section{Educational context}

The desire to educate people about her collection, and lace making generally, inspires Jean Hall to share her collection. She believes that it 'makes people more aware of a dying art, and what they've got at home, they'll value it, and treat it more respectfully, so it just makes them more educated and more aware'. John McCosh perceives public access to his collection to also have educational merit: 'we used to do a lot of school parties cos it's very educational, extremely educational'. Ian Ladds similarly described the ability for his collection to serve the educational needs of others:

[The Nelson Rock and Mineral Club] put up a display [at the Richmond Public Library] and it turned out that it was put up at just the right time because one of the schools was doing a geology project and [they] were able to come and have a wander and look (Ian Ladds).

Bruce Lyon makes use of his collection to educate people about road safety: 'being a good old ex-cop from a road policing background, [I'm] always trying to send a road safety message'. Fiona Campbell's emphasis on the educational value of sharing her collection publicly was her primary motivation to establish her collection: 'It was designed especially for the NCEA art students you know the kids who are actually studying art at a secondary level but don't necessarily have access to a public gallery'. She was therefore motivated to acquire and display collection items because of their educational value:

There [are] artworks in The Roadshow that I personally don't like, [but] I've been assured by [The Roadshow curators] that they have, say, an intellectual rigour or something to add to the curriculum, or some technical thing that the kids really need to be exposed to (Fiona Campbell).

\section{Enjoyment of others}

Jean Hall spoke of her museum 'bring[ing] joy to people', and Bruce Lyon talked about wanting 'to share [the collection] with people... who want to enjoy it'. Fiona Campbell also conveyed a sense of satisfaction with positive audience reactions to her collections: 
I was at a high school and this cool fifteen year old girl was going up the [Real Art Roadshow truck trailer] ramp going "oh this is going to suck, I hate art," and I thought "oh that's a big bold statement," and then five minutes later I noticed she was in engrossed conversation with her friend over an artwork, and I thought "hey maybe it's not all suck". And I just love it when that happens because I don't need them to love the project, I don't need them to love the collection, I just need one artwork to say one thing to them of encouragement and then it's all worthwhile. It is those little moments that are really rewarding (Fiona Campbell).

Fiona's statement directly contradicts the perspective that private collectors are primarily motivated to share their collections because they wish to be seen as 'great' (Sax 1999, 61). In stating that she does 'not need them to love the project' or 'the collection' Fiona refutes any claim that she is exhibiting her collection to receive the praise of others. The concept of praise as a motivation for display was however described by John McCosh in his comment that: 'I certainly get a real big kick out of opening the door and people saying "wow", I get great enjoyment out of that'. The gratification John McCosh receives from his public's enjoyment stems partly from the fact that it is often his taxidermy work that is being admired:

They say "have you mounted all this, is it all your work?" and it is all my work, it's what I've done. A lot of people say to me, “they're so lifelike" and that's the art of taxidermy, to make them lifelike. If people come in and say, “they look stuffed, they don't look real" I wouldn't get any enjoyment out of it, so I think it brings home to me that I've made a good job of mounting those animals. It's a two-way thing really. I do get great pleasure out of showing it to people (John McCosh).

Although one can see how the praise John McCosh receives plays a part in his enjoyment of sharing his collections publicly, findings show that it is not his sole motivation for doing so. The previous reference to the educational value of his collection and its benefit for school students suggests that John McCosh does not only exhibit his collections for the pleasure of others' reactions but for the perceived benefits his collection can offer others. 


\section{Instigation of others}

The express desire for others to view their collections motivated Jean Hall, Peter Smith, Alison Reid and John McCosh to first display collection items publicly. Jean Hall's lace museum sprung from the relationships she had with other lace enthusiasts:

I belonged to a lace society and there [were] various ladies in the different little areas and we [would] come together occasionally and they asked to come and see it. So... we had an afternoon and they had a look around it, and it just grew from then (Jean Hall).

For Peter Smith however, it was a general call to lend collection items for a shopping centre window display that sparked his desire to share his collection with others:

The first time was Kirkcaldie and Stains, they must have put... an ad in the newspaper saying they were interested in getting in touch with collectors and... I got in touch with them... and suggested that I could loan them the collection for their displays and they said yes...I came back around about two weeks later and they had filled out one shop window with my collection (Peter Smith).

Alison Reid first displayed her collection at the instigation of Wellington City Gallery curators Abby Cunnane and Aaron Lister, who were scouting for Crown Lynn ceramics for an exhibition:

Two curators came into the shop... and I thought, “ooh, wonder what they're looking for?" and as [curator Aaron Lister] was leaving - he was almost out the door - I said, “oh, are you looking for more Crown Lynn?” and he came back and he said, “yes, what have you got? And I said, "I've got some Colour Glaze," and then his eyes lit up and he said, "in the shop?" and I said, "no, no, at home," and so that's how I got involved with the Wellington City Gallery (Alison Reid). 
For John McCosh it was a visit from some American hunters that convinced him that he had a collection worthy of public display:

I had all of this stuff in my lounge of my house, and I had a workshop out the back, so when a lot of [the taxidermy] was finished I took it inside into the lounge. These Americans came through one day and they said, "I believe you've got a fantastic hunting collection," - they were hunters - and I said, "oh yeah," and they said, "can we have a look?" so then they came inside (John McCosh).

The curiosity and enthusiasm of others motivated these collectors to share their collections publicly for the first time. These collections, which had until then been private endeavours, became publicly accessible. The collectors' personal enjoyment of collection items was enhanced by the pleasure they perceived it offered others.

The expressed need of other members of the public to house their own objects provided further motive for John McCosh, Jean Hall and Bruce Lyon to share their collections publicly. John McCosh referenced how shared values with other private collectors had enabled him to acquire the collections of others:

The Grey family in Martinborough had a big private museum...a rock collection. Roger, he was a rock hound and he actually started the rock club in New Zealand. When he passed away they donated to me, because his wish was that the collection be kept in the Wairarapa. It complemented what I was doing. It was incredible really. Then further down [the] track there was [the] Robertson collection up in Wanganui. There was a big museum there that closed down and they were looking for somewhere [for] it to go. The Wanganui Museum wanted it, [but] because like most collections of museums you never see them...they certainly didn't want that to happen, and they heard about my taxidermy natural history museum and thought, "would I be interested?" and [of] course I was (John McCosh).

The public confidence that the facilities of private collectors were an appropriate place to display objects equally influenced the collecting activities of Jean Hall and 
Bruce Lyon. Describing the 'special' qualities of donated items Jean Hall explained 'often I'll be told we've got only boys in our family and they're not interested at all, and nor are their wives, we don't know what to do with it but we'd love to have it here so other people can appreciate it'. Bruce Lyon viewed the deposit of family possessions as adding an additional layer of responsibility:

What we're talking about is in family possession and nobody knows what to do with it. "Granddad's police uniform, well what am I supposed to do with it?" It sits in a box, sometimes it goes to the dump with a whole lot of other stuff over the years, and a lot of history gets lost. So to think that people think this [museum] is good enough to bring those things into, adds an extra responsibility to me, because now I can't walk away from it (Bruce Lyon).

\section{Institutional values}

The sense of responsibility Bruce Lyon feels echoes the philosophies that guide the work of public heritage institutions. Geoffrey Lewis, former chair of the International Council of Museums Ethics Committee, encapsulates the public responsibility of the museum in his statement that the purpose of the museum is:

the preservation of society's collective memory as expressed tangibly and intangibly through the cultural and natural heritage. To do this, however, is meaningless unless it is associated with access to and the interpretation of that memory. Those responsible for providing museums and those who engage in providing all aspects of the museum service undertake a public responsibility (Lewis 2004, 15).

Lewis' statement affirms that public responsibility is closely related to the activity of interpretation, a practice of display. The significance private collectors place on the activity of display to educate their public about the value of the objects they collect unifies the ethos of the private collector with the heritage institution. In this respect it becomes evident that the display of objects is related to both protagonists' perceptions of value. This aligns their views with Pearce's schematic diagram of value, 'Collecting in relation to perceived valuation' (Figure 2), which shows that the 
activity of display can be used as a vehicle to authenticate objects for others (Pearce 1998).

Further to the identification that the significance of display unifies the ethos of the private collector and heritage institutions within the heritage sector, is an appreciation of the shared values both agents wish to communicate through this activity. These values are discussed within the context of the private collectors' collecting activities in the next chapter

\section{Summary}

The heritage sector is participatory in the social world of the private collector. Private collectors are members of the public that the heritage sector serves and some actively collaborate with heritage institutions. Findings show that the blurring of boundaries between the private collector and the heritage sector, is not only physical, with private collectors visiting heritage institutions and loaning objects to them, but it is also intellectual with the cultural capital of the private collector being equivalent to that of the heritage institutions within the heritage sector. Capable of understanding the activities of heritage institutions because of their cultural capital, private collectors are also capable of identifying different ways in which their functions may be carried out. This leads private collectors to question the symbolic capital of heritage institutions and distinguish their agency from them on the basis of their subjective tastes.

Findings also showed how it was possible to examine the agency of the private collector in relation to the heritage sector through abandoning a hierarchical schema of micro and macro. This facilitated an exploration of the agency of the private collector in relation to the staff of heritage institutions. It showed that private collectors acknowledge the existence of professionals within heritage institutions, challenging Stebbins's (2007) definition that the private collector has no professional counterparts. Findings further revealed that private collectors distinguished their activities from 'professional' staff in heritage institutions based on the identification of specialist skills of staff, and the perceived autonomy they had over their collecting activities as 'non-professionals'. This autonomy enables the private collector to enact their collecting practices in accordance with their own subjective tastes. For some this 
was described in their ability to privilege the activity of display over that of preservation.

An examination of the values that motivate the private collector to share their collections publicly revealed they did so because of the relationship they had to the objects they collect and members of the public that participate in their social world. These values constitute the ethos of the private collector who shares their collections publicly. It was found that the significance private collectors place on the activity of display as a means by which to communicate values to others unified their ethos with members of the public they serve and the heritage sector. This showed that the private values collectors placed on the activity of display were related to wider cultural understandings of value, supporting Richins's (1994) and Morrison's (2010) suggestion that private values are related to public values.

The next chapter extends this analysis of the private collectors' display practices to include an examination of their collection and preservation practices. These practices are considered in relation to the private collectors' subjective tastes, their ethos and the heritage sector. 


\section{Chapter Three: The collecting practices of private collectors}

That clinical aspect of a museum.

(John McCosh)

The previous chapter discussed the private collectors' capacity to differentiate their practices and tastes from heritage institutions within the heritage sector. It further identified how the significance private collectors placed on the activity of display unified the ethos of the private collector with the public they serve and the heritage sector. This chapter considers the private collectors' capacity to produce classifiable practices and products in accordance with their own subjective tastes (Bourdieu 1984). It discusses how the ethos of the private collector is communicated through their collecting practices, further extending this analysis to consider how their collecting practices and the values that underlie them reflect or differ from heritage institutions within the heritage sector.

In doing so it acknowledges the central tenant of actor-network theory, that an agent is a product of both human and non-human interactional effects (Law 1992). It explores these interactional effects in two ways. Firstly it examines the relationship private collectors have to the objects they collect through detailing the collection, display and conservation practices of private collectors. Secondly it discusses the future private collectors envisage for their collections, to examine the relationship they have to the objects they collect and to other human agents who they shall entrust them to.

In attempting to position the private collector in relation to the heritage sector I also compare their collecting practices to 'best practice' standards. This framework provides a practical means by which to compare the collecting practices of the private collector to heritage institutions within the heritage sector. It was chosen because of the importance the heritage sector places on best practice standards (Museum of New Zealand Te Papa Tongarewa 2007), and the understanding that the heritage sector is 
fundamental to the positioning of the private collector in accordance with my research aim. I draw on best practice standards purely for the purposes of comparison. By this I mean that best practice standards shall not be used as a moral compass to determine how good or bad the private collectors' collecting practices are, but rather as a means to compare the collecting practices of the private collectors with those of heritage institutions within the heritage sector. The values private collectors place on their collecting activities is also examined in relation to heritage sector literature. This examination of practices and values seeks to further understand how the private collectors' ethos is consistent with or differs from the heritage sector.

This chapter divides my discussion of findings into the collecting practices that are associated with the functions of collection, display and conservation. It concludes by discussing the future private collectors envisage for their collections.

\section{Collection}

The collection practices of the private collectors can be further divided into those that relate to acquisition, selection, deselection, research and cataloguing. They are discussed in relation to my findings below.

\section{Acquisition}

The private collectors with whom I spoke acquired their collections through various means. Some sourced collection materials passively through the process of donation (John McCosh, Jean Hall, Bruce Lyon and Ian Ladds), while other collectors engaged with the process of active acquisition - swapping collection items with other collectors (Bruce Lyon), producing collection items (John McCosh, Jean Hall) or collecting materials from the field (Ian Ladds). Seven out of eight collectors spoken to (Jim Barr, Fiona Campbell, Peter Smith, Alison Reid, Jean Hall, Ian Ladds and Bruce Lyon) also purchased collection items. These collectors sourced new acquisitions at online auction sites (Alison Reid, Peter Smith, Bruce Lyon, Ian Ladds, Jean Hall), auction houses (Peter Smith, Fiona Campbell), second-hand shops (Alison Reid, Peter Smith, Jean Hall), or through art dealers (Jim Barr, Fiona Campbell). 
The motives to acquire collection materials were founded on the values private collectors placed on the objects they collect. Bruce Lyon, for example stated: 'It's not the monetary value it's the historical value, or the aesthetic value'. The historical value to which Bruce refers, also motivated Alison Reid to acquire collection items:

I never look at them and go that's the dollar value... see there's two types of collecting you're collecting for an investment or you're collecting for what I say the historical. I'm collecting from a historical point of view, so I can't let money enter into it, once I've paid for something that's it I almost immediately forget how much it's cost (Alison Reid).

Peter Smith and Jean Hall's motives to collect stem from the educational value they perceive objects to have. Expressing that the activity of collecting was 'an education' for him, Peter Smith advised that he 'would buy damaged pieces just to actually look at them get a feel for the texture, study it and see if I could understand how it was manufactured'. Jean Hall explained that when she learnt to make lace 'it bec[a]me obvious that each country did it slightly differently and then it became interesting to collect bits from those areas'.

As discussed in Chapter Two the motive for Fiona Campbell to collect was synonymous with her motive to display. Perceiving the artworks she collected to have educational value, Fiona Campbell also cited her motive to collect as the need to give back to others:

When we sold our Trade Me shares that sort of bought about a few kind of questions. What do you actually do with truckloads of money? We always had a conscious knowledge that we needed to give back to the community somehow... so we put together an art project called The Real Art Roadshow, which takes art to schools especially sort of regionally isolated schools, and it's real art, it's good quality art (Fiona Campbell).

The ability for the acquisition of objects to unite private collectors with other human agents was also described by Jim Barr: 'we see really the work that we buy is a partnership with the artist. We've always felt that very strongly, so that if we ever sell 
a work we give half the profit of the thing back to the artist so that's been a big factor in the value of the collection'. Jim went on to say: 'of course that has always made us feel that if we sell something that it's easier for us in a way'. Jim Barr's statements suggest that the financial value of collection items he acquires is an ethical obstacle to overcome, a sentiment also echoed in Fiona Campbell's statement that: 'investing in art in a cold blooded way is quite ethical, you are investing in peoples' personal creativity and by sharing the collection you are investing in the wider audience, and allowing that sort of creative spirit to run through a bigger audience'.

Ian Ladds was also eager to distance his motive to acquire collection items from that of financial gain:

It comes back to the business that those that buy collections or chase the glory specimens don't quite have the same thing for it and some of them tend to have a passion for the commercial side of it and I don't. Yes there's money in it, some people would say there's lots of money in it, but it so easily drops into greed. If you're making money out of it there's an ethical line somewhere (Ian Ladds).

These statements support Russell Belk's observation that 'making money is anathema within most collecting circles because it leads to the charge that someone is "only in it for the money," and thus not a sincere, devoted, passionate collector' (Belk 1995, 79$80)$.

In articulating why he acquired collection materials, Ian Ladds said: 'originally it was to collect just for the fun, but now as I've got older I've shifted to [collecting] for other people to see and know'. He further commented that collecting 'helps me understand the geology', which enables him to 'argue with the scientists'. Ian's interview was littered with references to support these motives. In it he continuously referred to his relationship with GNS to identify specimens and in some instances gift specimens to them.

John McCosh was motivated to collect because of his passion for the art of taxidermy: 'I like to sort of think that this is my collection... it's all my work. I don't buy other 
taxidermy stuff in, so it's all my work so it's just whatever I've been able to sort of lay my hands on'. He further explained:

The art of taxidermy is [to] create them as lifelike as possible, and you don't like to make them look as though they're stuffed. There's two concoctions with taxidermy, you either mount them or stuff them. I don't like using the word stuffed, I like to sort of say, I mount them because you actually mount them over a mannequin. In the old days they used to be stuffed... all disjointed and goodness knows what...what's actually inside all my animals is a polystyrene mould, so it's very very important to get the mould with all the muscles and everything exactly right before you put the skin over it (John $\mathrm{McCosh})$.

The data strongly suggest that values other than financial motivated the collectors I spoke to, to acquire collection materials. Citing the historic, educational, scientific, and aesthetic value as motivating them to acquire collection materials, these values can be seen to echo those espoused in heritage sector literature such as Significance 2.0 (Russell and Winkworth 2009).

While the values may be synonymous with those of the heritage sector, the acquisition practices of the private collectors do differ from publicly funded heritage institutions. The acquisition practices of these private collectors remained undocumented in so far as they did not have a formal policy that governed their acquisition process. Governed by policies, which in a best practice sense should reflect their mission, the New Zealand heritage institution and its workers are ethically obligated to document their acquisition and disposal practices in accordance with Museum Aotearoa's Code of Ethics For Governing Bodies of Museums and Museum Staff (Museums Aotearoa Te Tari o Ngā Whare Taonga o te Motu 2003). The lack of formal policy surrounding these private collectors' acquisition and selection activities, demonstrates how the practices of the private collectors, with whom I spoke, differ from those heritage institutions that adhere to best practice standards. I believe this difference in practice can be attributed to the private collector's autonomy over their collecting activities. This theory is supported by Fiona Campbell's observation that she had 'just been busily doing my project rather than doing all that admin malarky', as well as Bruce 
Lyon's statement that:

I think some museums these days particularly ones that are owned by corporations or by government departments...follow the corporate five-year plan. It insures they get funding... I think that a thing like this that is not a corporate speak for the organization is a great way of doing it and that's what I've tried to aim at doing (Bruce Lyon).

In describing the benefits of his collecting activities occurring outside of organizational structures, Bruce foregrounds the perceived advantage private collectors feel they have as autonomous individuals. This raises a fundamental distinction between the collecting practices of the private collector and those of the heritage institution. The practices of the private collector reflect those of an individual agent, whereas the practices of the heritage institution reflect those of many individuals.

This is not to say the activities of private collectors occur in isolation. The acquisition practices of Jim Barr, Fiona Campbell and Ian Ladds also highlight the role other human agents play in determining their acquisition activities. For Jim Barr it is artists, for Fiona Campbell it is school children and for Ian Ladds it is the general public and a community of scientists. These humans who inhabit the social worlds of the private collector can be seen to also influence the relationships they have to the objects they collect. The distinction between the practices of the private collector and the heritage institution however, is that other people have no control over the collecting practices private collectors employ.

\section{Selection}

Though informal, the private collectors I spoke to did have selection criteria that governed their acquisition decisions. Broadly described by Bruce Lyon's statement that: 'If you look there's so much stuff it's really a matter of what do you want, what can you afford and what are you trying to achieve with the piece you buy'. Alison Reid described her need to make selection decisions in her statement that: 
When you collect you have to make decisions and you have to make editing choices and back in the early days it's like going around the monopoly board, buy, buy, buy, buy, buy, and then it gets to a point ...that you actually have to go right I have to make some choices here I have to edit this down (Alison Reid).

Jim Barr and Fiona Campbell made their selection decisions in conjunction with others, further supporting the claim that the relationship these private collectors have to the objects they collect is influenced by participants who inhabit their social worlds. Viewing his collection as a joint venture with his wife Mary, Jim remarked: 'we've always both seen what we're going to buy, we always agree on it. If one of us disagrees we wouldn't buy it'. He further explained that:

If there was a story of the collection it's been that we've collected people when they've been in their sort of late twenties to mid thirties and then...mostly their careers have taken off and we've moved back down so it's been a series of steps like that (Jim Barr).

Fiona Campbell explained that she purchased collection items in conjunction with curators she had hired for The Real Art Roadshow.

For the Roadshow... we [Rob McLeod, Gerald Barnett, Fiona Campbell] had a shopping list of the thirty big names in art that we wanted to get for The Roadshow Collection, but it was interesting, for every big name artist that we were sourcing there'd be some emerging or mid-career artist that we'd think "hey they've got just as much going on in their artwork as a senior practitioner". So we'd designed the first collection to be about thirty pieces it ended up being sixty-four (Fiona Campbell).

Evident in Fiona Campbell's selection criteria was the educational merit of artworks as discussed in Chapter Two. For Alison Reid however selection criteria hinged on aesthetic sensibilities: 
The decision I made in terms of collecting is, for example there's twenty seven colours of Colour Glaze, within that the fourteen core colours where you can get full dinner sets, full jugs, egg cups all the condiments. I had to decide the numbers that I was collecting. I based it on how good the stack looks so purely from an aesthetic point of view I've gone in fours. So four dinner, four lunch, four side, four soup, four dessert with the cups and saucers again from an aesthetic point of view I collect seven (Alison Reid).

And completeness:

It's probably about ninety-eight percent complete, I'm sort of one dinner plate away from completing the whole dinner service and you know a year ago I was forty two... dinner plates away so I will complete it, that's unequivocal, no doubt about it (Alison Reid).

Jean Hall and Ian Ladds based their selection decisions on representation. Jean Hall explained: 'I feel the collection is a good example of all the different aspects of it and unless it's what I haven't got I don't collect it'. Ian Ladds's desire to have a representative collection was however closely aligned with his future ambitions: 'What I'd like to do in the future is to have a sample of every fossil that we can find out of this area'. That the selection decisions of these collectors were influenced by representation, relates their practices to those of the heritage sector as purported in Significance 2.0 (Russell and Winkworth 2009).

For Peter Smith who saw the activity of collecting as unrelated to the production of a collection in and of itself: 'there is no particular single collection there's just the habit of collecting that just keeps going and going', selection criteria was also apparent: 'I try not to just add... to the collection and I've had to do that with the Stuart [Crystal collection] as well, I don't buy duplicates. It's got to be different from anything that I've got. That's my rule' (Peter Smith).

The purposeful acquisition of collection materials aligns the activities of the private collectors with whom I spoke with that of the heritage institution: 'At the heart of any policy on your collection lies your identity and purpose as a museum. Your collection 
is a focus of your organisation's mission' (Museum of New Zealand Te Papa Tongarewa 2003, 2). The difference of course, as previously discussed, is that this mission is not formally documented.

\section{Deselection}

The term deselection has been chosen to describe the private collectors' removal of objects from their collections. It was selected because not all of the private collectors with whom I spoke had accessioned items. As such the term deaccession was not appropriate, as items were not accessioned in the first instance to deaccession material. This shall become apparent in the section on cataloguing which directly addresses the topic of accessioning.

Three of the private collectors I spoke to deselected collection items. They did so by gifting collection items to others (Ian Ladds, Jim Barr) or selling collection items (Peter Smith, Jim Barr). Ian Ladds and Peter Smith deselected collection materials because they were superfluous to their needs, whereas Jim Barr often did so because particular works presented preservation challenges. It was found that the deselection practices of these private collectors were closely aligned with the values they placed on their collection activities and the activity of sharing their collections publicly.

Ian Ladds, saw the deselection of duplicate collection materials as a way of inspiring others: 'I've certainly given a lot to some youngsters, in fact there's one I'm thinking of particularly at the moment [who] needs encouragement and help, so I actually made up a little collection of stuff. I have extra stuff here that I can do [that with]'. Ian Ladds advised such 'youngsters', to 'collect what you can collect today that's as good as you think you can get, and if in the future you get a better one you pass your older one down the line to someone else, so that they [have] something to encourage them'. Ian has also gifted material to GNS Science, 'New Zealand's leading provider of Earth, geoscience and isotope research and consultancy services' (GNS Science Te Pü Ao, 2012).

I've got some beautiful pieces of a crustaceous palm leaf...one of those has got a seed on it, which I've shown to folk at GNS, and they're quite 
impressed. I have collected some stuff that I've sent to them and let them have because they've said "we haven't got any" or "we'd like a piece, can we keep it?" so I'm very happy to do that sort of stuff to from time to time (Ian Ladds).

Ian Ladds's deselection philosophies relate to the value he places on his collection to educate and entertain others.

The preservation needs of materials caused Jim Barr to deselect collection materials on the basis of their fragility. Giving artworks to galleries and selling others, Jim Barr explained 'we've sold works because we couldn't look after them, very delicate works that we just found difficult to own'. Indicative of the responsibility Jim feels towards collection items, Jim Barr's statement conveys his desire to privilege the preservation of materials over his ownership of them.

Peter Smith deselects on the basis that he is unable to house collection items due to space constraints, is no longer able to add to the collection, and that the historic and aesthetic value of the collection materials is no longer apparent to him.

The whole thing with collecting is that you want to find it and it's been discarded, if it's already coveted it's not that interesting, and you're not going to find the opportunities to collect like you normally do if things have just disappeared off people's radars. So the moment it becomes popular I start to lose interest, and because everybody's collecting the prices are going up so that's the competition. I'm starting to think there's not opportunities to add to my collection anymore, it's pretty much frozen. If I can't add to my collection why have I got it? That's pretty much my thought processes. Those would be the most common reasons that I would start to drop collections, the value, definitely I would start selling when it's starting to achieve good prices and also the practicalities of perhaps there's insufficient storage, or it's just been sitting in storage for too long, I probably won't display it again, it doesn't fit with my décor or it doesn't have any context (Peter Smith). 
When probed further about the financial incentive to deselect collection materials, Peter Smith advised that he would not necessarily sell a collection item if it were financially valuable:

Not necessarily...you want to live with it and you want to appreciate why [it is]. I have a piece of Lalique that is way more valuable than what I paid for it but I wouldn't sell it just because it is just one of those pieces. It's the provenance behind it. It's the way that I found it (Peter Smith).

That this private collector, like all of the collectors with whom I spoke, would not necessarily sell collection materials on the basis of their financial worth, affirms the previous observation that the financial worth of these private collectors' collections remains secondary to the historic, aesthetic, social or educational significance they place on their collection items. The refinement of their collections for purposes of education and preservation aligns their philosophies with best practice standards (Ladkin 2004).

\section{Research}

In discussing the significance of research to their collecting activities, the private collectors with whom I spoke described various resources they found useful in educating themselves about the objects they collected. For example Peter Smith explained:

You get passionate and then you start to research... The internet is one source but typically the library is very useful as well... You're better off covering a lot of bases... Joining a club is... another way of exchanging information... Also going to certain areas. I was just recently in Auckland, so I went to New Lynn, which is where Crown Lynn was based, just to actually go to the physical place and discovered that the New Lynn Library has a... very small but it's... an important collection, so I was able to look there as well. In the context of collecting you are always trying to find out some more information and ...it helps talking to shop keepers, and also talking to other people, and finding out what their stories are, and you know some of those stories are 
amazing they fill out gaps that nobody ever knew of so... it's just a whole range of activities to sort of build that knowledge up (Peter Smith).

Alison Reid also elaborated on how the stories of others had enhanced her knowledge of Crown Lynn:

What I've found is people will come into the shop and say "oh I used to work for Crown Lynn" and so I spend ten minutes, half an hour, with them and write down all of their notes... I try to tell Crown Lynn workers especially "[to] write your stuff down pass it onto your children". I'm really worried it's going to be lost, I'm worried that there's not enough happening out there to gather this information. I went to the Film Archive and there's only three pieces of footage and one's seventeen seconds long, and the longest one is three minutes. I think "ah" what's going to happen, so I write it down in a notebook and am trying to do my best to capture it all (Alison Reid).

Ian Ladds explained that his research had involved both academic study and learning in the field:

I did two ten-day Victoria University extension courses. They used to do holiday programmes in the Christmas holidays. One was in the Wairarapa and one was down here in Nelson, and I think that was the one that really did spark the bug, it was just fabulous...Part of early learning was...we used to go to the beaches and beach comb, pick up pebbles and bits and pieces (Ian Ladds).

The relationship between collecting and research was also conveyed by Jean Hall in her statement that: 'It made...collecting more interesting because you could research in depth and I'm quite interested in history so that sort of helped me start collecting'.

In the course of conducting interviews I often found that private collectors were keen to educate me about the objects they collected. This suggested to me that the educational value private collectors placed on the objects they collected extended to the value they placed on the ability for their collection to educate others. The private 
collectors' commitment to the education of others was also evidenced in their creation of research resources. Fiona Campbell, for example had produced books and educational workbooks for schools:

We've got resources, printed resources, and web based resources that we've written specifically for those artworks. What's on the web and in the books, and the workbooks and stuff, is an essay written for an intelligent sixteen year old, which is apparently the level of reading that most of our population is at... We made sure that the essays were... relatively devoid of art wank because I'm allergic to art wank and I don't see it... has any purpose educationally apart from....art historians all talking together at a cocktail party and trying to out art wank each other... so we... try and keep those essays as... accessible as possible and we're not talking about dumbing down here, we're just talking about how to add to the enjoyment of an artwork rather than make you feel...stupid (Fiona Campbell).

Jean Hall explained how she communicated information about her collection to others through an index system:

I have a number on a wee tag... so that anyone can come along and look up the index and then I also have a number hanging on the right hand side of the frame...so that people if they were looking for a certain number [they] could find [information on] it (Jean Hall).

Alison's Reid desire to educate others was communicated in her long-term goal to make a catalogue that would make it 'easier for other people' to find out information about Crown Lynn.

The research activities of these private collectors reflect the outcomes best practice research standards hope to achieve:

Research on museum collections and publication of the findings provides a particular type of access to the collections, and allows museums to address their education and interpretation mission. It makes specialized information 
available to various interested parties and provides the basis for exhibitions and educational programming (Ladkin 2004, 29).

\section{Cataloguing}

Three collectors - Fiona Campbell, Jim Barr and Bruce Lyon - explained they had database software to catalogue their collection materials. However two of these collectors - Fiona Campbell and Bruce Lyon - preferred to use spreadsheets, notebooks and index based registers. Alison Reid and Jean Hall also employed these methods.

In reflecting on his approach to cataloguing materials Jim Barr said: 'we're pretty thorough I mean we've got a database and we were curators so I mean we have got a history of thinking about objects in terms of documentation'. He described the information he inputted into his database as:

The title, the artist, the date it was made, the dimensions so the catalogue details. Then it's got what it's made of, what exhibitions it's been in where it's been reproduced how much we paid for it... how much it's insured for... when it's toured... and where it is H, D, or question mark (Jim Barr).

This information was consistent with the types of information Fiona Campbell entered into her spreadsheets:

Each artwork has a... code, name, title, medium, year, all that sort of standard stuff but then some external internal measurements, which is helpful if I need to shift work, condition report which is not thorough... you know excellent, some chipping, complete basket case, that sort of thing, where I purchased it from when I purchased it...the price I paid for it (Fiona Campbell).

In explaining the method in which she catalogued her materials Jean Hall said:

I have an index where I'll...put in what it is and it's number and when I got it, was it a gift or how much did I pay for it, and then I've got extended books 
that will match that number and I'll have photographs of it and all the... information I have gleaned about it written in it. I normally say what colour it is, whether it's linen, or cotton, or silk... and the technique... and if I can get the history of whose it was and... a bit of their life history to put with it...I will put it in there (Jean Hall).

Bruce Lyon also employed an index-based system to catalogue materials, stating:

A lot of the stuff I've got from people I make sure I keep a record of who and where and... things like that and what they might have cost me. A lot of it is say for instance... cap badges or caps, in due course I'll add more information to each one but it's very hard to. I mean I've got a Russian police hat ...that's a traffic unit one it's very hard to then add more information to that because they're generic over a number of years and... some of the old stuff... very much more important to do that. In the ideal world...you'd have everything catalogued perfectly you'd have everything known perfectly (Bruce Lyon).

Three collectors - Ian Ladds, John McCosh and Peter Smith - consciously chose not to catalogue items in their collections. They cited the small size of their collections (Peter Smith); the ability to recall memories associated with each collection item (Ian Ladds); and their autonomy over their collecting activities (John McCosh), as reasons not to do so. These collectors were aware that not cataloguing their collections differed from best practice standards. For example Ian Ladds conveyed: 'Reality is I'm a naughty boy I don't do it', while John McCosh maintained 'It's just my own collection...so... it hasn't sort of taken on that...clinical aspect of a museum'.

The cataloguing methods of Jean Hall, Fiona Campbell, Jim Barr, Bruce Lyon and Alison Reid most closely reflect the best practice standards of heritage institutions 'the museum should aim to establish records about each of the items in the collection and continue to extend these records as the objects are examined and used' (Roberts 2004, 33). Employing tools such as databases, registers and indexes these collectors documented specific information regarding physical and intellectual properties associated with their collection materials. Divergent from best practice standards were the cataloguing practices of John McCosh, Ian Ladds and Peter Smith, whose lack of 
documentation was expressed as a personal choice. Their choice not to catalogue further highlights the autonomy these collectors have over their collecting practices.

\section{Display}

The previous chapter discussed how the relationships private collectors had to their objects, their creators and the public they served motivated them to share their collections publicly. This section offers a deeper analysis of the private collectors' display practices, addressing how and why private collectors make their display choices. It is divided into the following factors, which were identified as influencing their display decisions - physical space, selection, interpretation, and visitor feedback. The discussion of these factors is accompanied with frame-grabs, which seek to offer a deeper context in which to interpret these findings.

\section{Physical space}

Evident in John McCosh's, Fiona Campbell's and Bruce Lyon's descriptions of their display practices, was how the physical space in which they exhibited their collections influenced their display choices. For example John McCosh revealed:

It's just whatever room I've had, like with the big wall there...I've put the biggest heads on that wall...I've probably done the collection to suit the building but then I built the building to suit the animals as well so I sort of worked it out roughly (John McCosh).

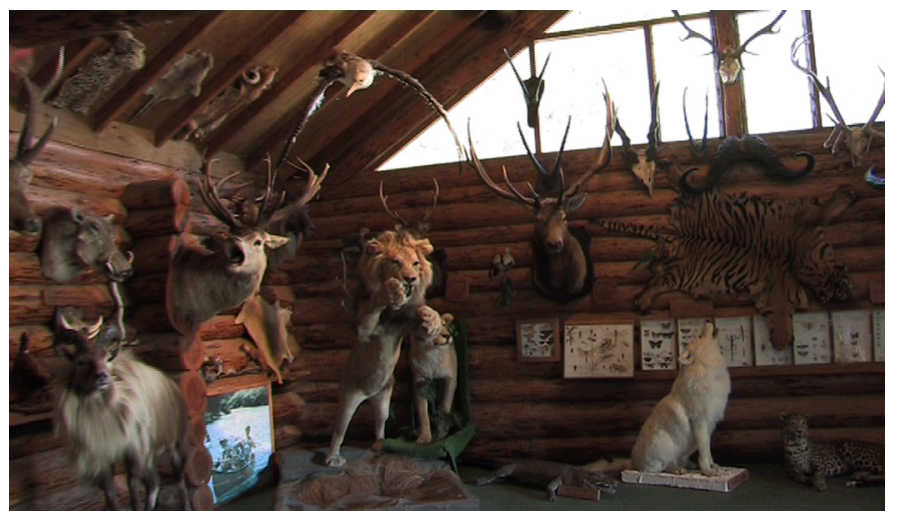

Figure 12. Wall featuring John McCosh's large heads. Frame-grab taken from interview footage captured at the Kahutara Taxidermy Gallery, Featherston, 07 October 2011. 
Fiona Campbell described that the artworks in The Real Art Roadshow collection were curated in accordance with the physical space in which they were installed.

We'd designed the first collection to be about thirty pieces, it ended up being sixty four, which means in The Roadshow the art is everywhere, it's not some nice tidy polite hang all at prescribed eye level...The art is hung at eye height and down low and up high and unexpected places, and there is so much of it in there (Fiona Campbell).

Fiona Campbell provided greater detail regarding these curatorial choices, in describing the installation process:

We put them on the panels, and size wise we could group some things kinda intellectually together, but sometimes things would be orphaned and we'd think "how's this going to work?" and then we put them in The Roadshow, and I don't know it just hangs together really well... I just know for kids there's so much sound, and light, and colour, and action, and movement in their lives that you have to do something a bit special to capture them with static artworks, and that whole jammed crammed kind of ability of The Roadshow just for our practicalities of things, just trying to get all these works in there, has been a real bonus (Fiona Campbell).
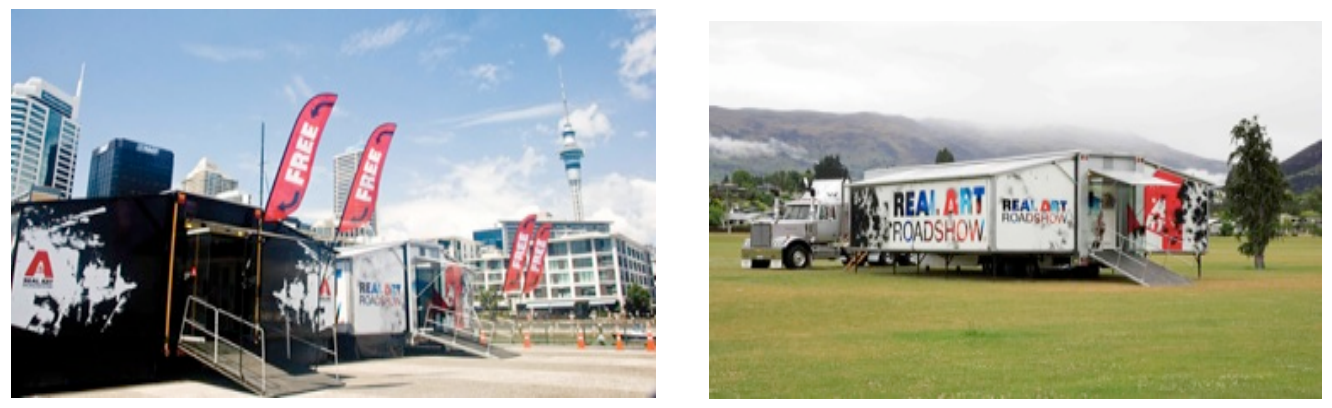

Figure 13, 14 (left to right). Figure 13. The Real Art Roadshow Black and Silver Collection trailers.

Figure 14. The Real Art Roadshow Silver Collection truck and trailer. Images obtained from The Real Art Roadshow "Photo Gallery", with permission of Fiona Campbell. 

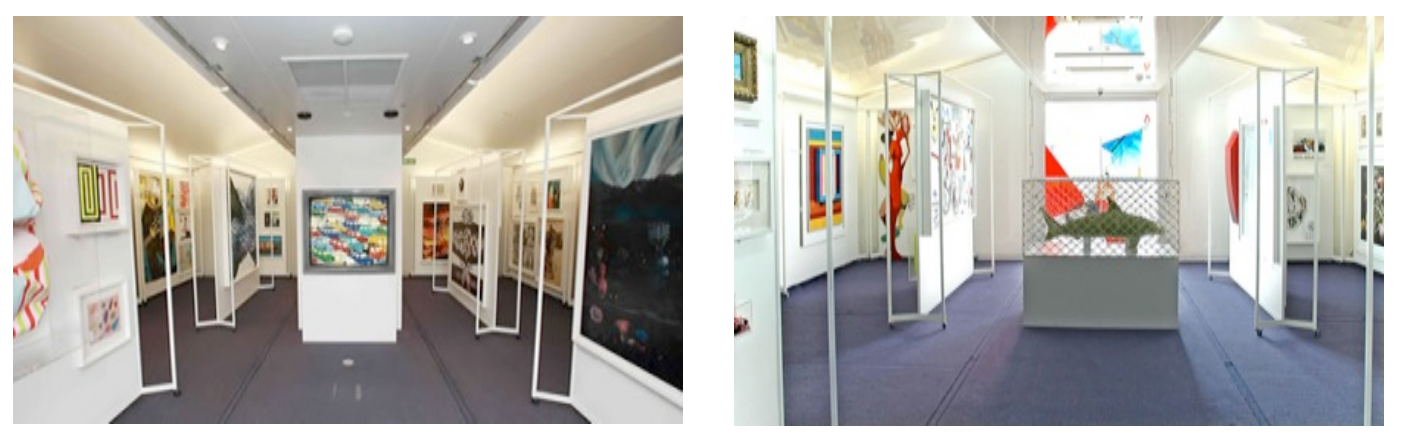

Figure 15, 16 (left to right). Figure 15. Interior of The Real Art Roadshow Black Collection trailer. Figure 16. Interior of The Real Art Roadshow Silver Collection trailer. Images obtained from Real Art Roadshow "Photo Gallery", with permission of Fiona Campbell.

Unlike John McCosh's and Fiona Campbell's collections, Bruce Lyon's collection was displayed in an existing structure: 'The building itself was built in 1922, it's the old Public Trust building for Dannevirke'. Charmed by the age and character of the building, Bruce Lyon articulated how the height of the building allowed him 'to put things almost on two levels and display things like some of the uniform stuff higher up where it can still be easily seen'.

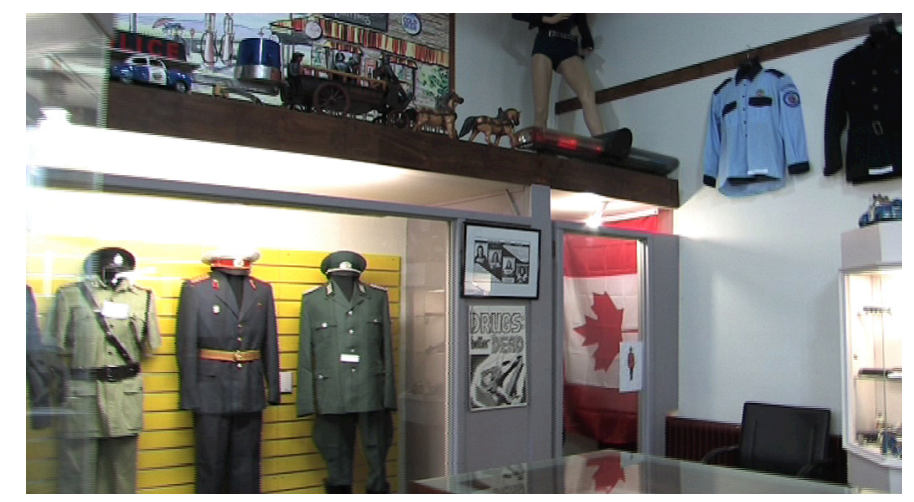

Figure 17. Uniforms on display at The International Police Museum. Frame-grab taken from interview footage captured at The International Police Museum, Dannevirke, 28 October 2011.

When Bruce Lyon 'ran out of space' inside the building he erected 'a seven car carport out the back... to house the vehicles'. He was also currently 'in the process of building a sheriff's office into the garage' at the time of interviewing. In explaining the display decisions he makes, Bruce Lyon said: 'it just evolves and it will continue to evolve. I mean there's stuff I want to move now but it's a matter of every time you want to move something that affects something else, so it's the big picture'. 

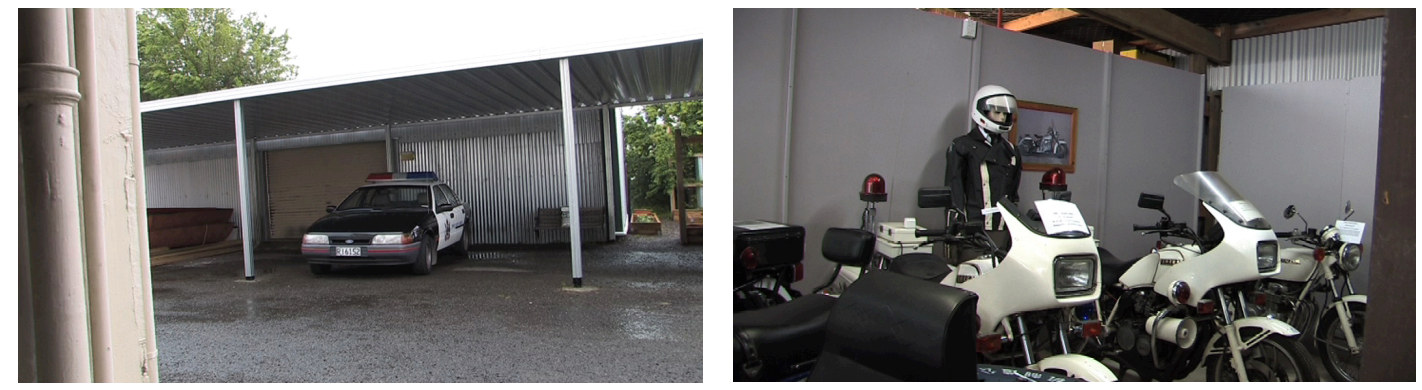

Figure 18 -19 (left to right). Figure 18. Carport at The International Police Museum.

Figure 19. Interior of garage attached to carport. Frame-grabs taken from interview footage captured at The International Police Museum, Dannevirke, 28 October 2011.

\section{Selection}

Jean Hall displayed her materials according to style and the country to which the style relates. Her display methods revealed the role selection played:

The area over there is Continental and behind me is mainly New Zealand... further on there's Middle Eastern lace and then behind the door... is Irish... and then the Scotch, on the left of it is Bulgarian and Idrian and after the Scotch there's German and French and Italian...so I've mainly [grouped them according to] countries (Jean Hall).
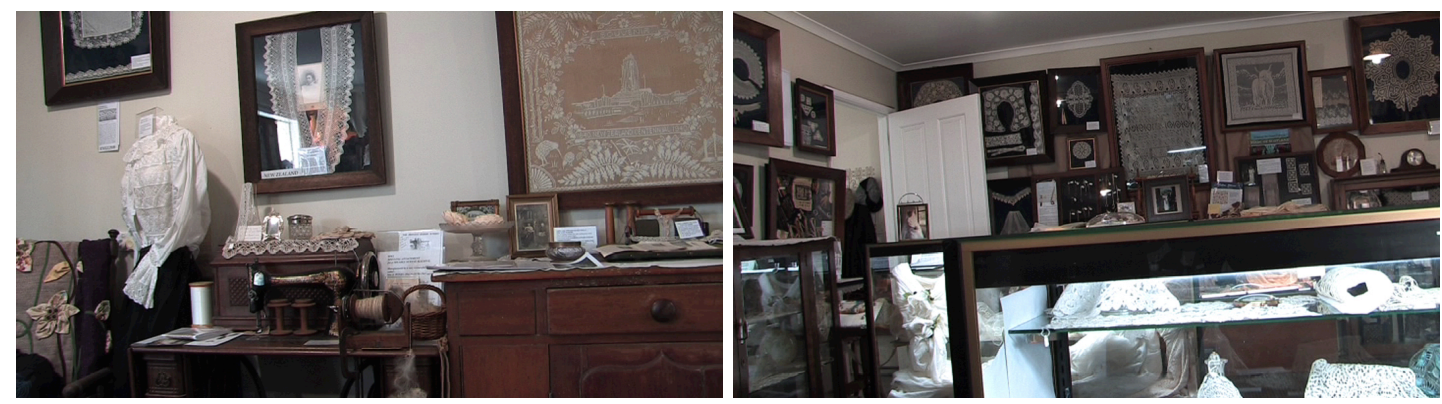

Figure 20-21. Jean Hall's lace collection grouped according to style. Frame-grabs taken from interview footage captured at Lillia’s Lace Museum, Geraldine, 23 October 2011.

External to the inner-workings of institutions that display their collection items, the collectors who loaned collection items - Alison Reid and Jim Barr - lacked autonomy over how institutional curators displayed their collection materials. These collectors therefore answered questions regarding their display practices by explaining the selection decisions they had made within their own home. For example, Jim Barr said: 
Here they're arranged and displayed so we can see them and often so that we can look at one thing against another so... in this room we turn things around a lot. There's a whole lot of things we bought recently that are white, so it's a not a very clever curatorial idea, but it was interesting to put them together. The interesting thing was not their whiteness so much as... that...there's a painting there by Campbell Patterson, whose really known as a...video artist, but...its a very charming painting, next to a...Martin Creed ball of screwed up paper, I mean you know it's...very interesting to see a young artist going into painting as a conceptual idea... and then a conceptual object next to it, that sort of thing. They're conversations that...we'd have that are not necessarily going to be that riveting to other people but... I think that all these objects can talk to each other... across... generations and across ideas and across... materials and we've got the luxury of doing that without people like us coming into the gallery and saying "oh that's really stupid" you know "why have you got that there that doesn't look very interesting". When we display things it doesn't have to be of interest to anyone but us really and that gives you a huge amount of liberty (Jim Barr).

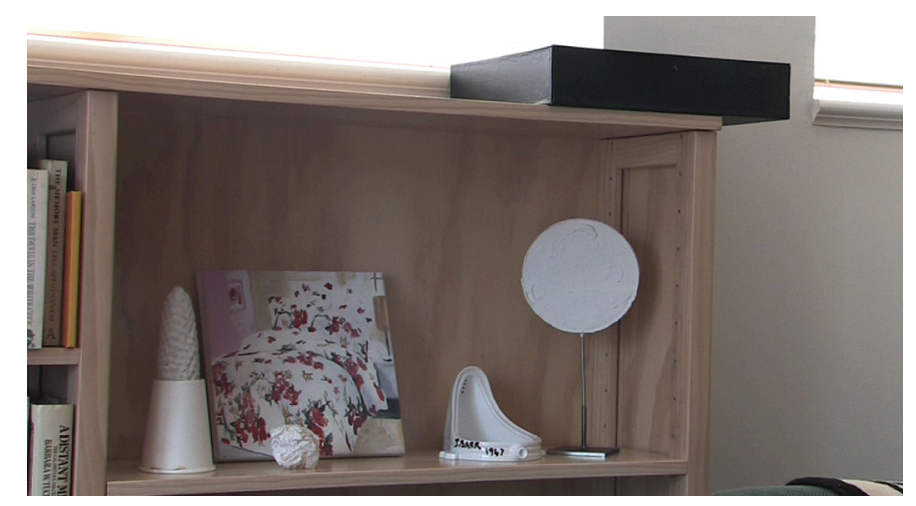

Figure 22. Items from Jim Barr's collection. Frame-grab taken from interview footage captured at Jim Barr's Wellington apartment, 03 October 2011.

Jim Barr's rationale for display reflects his personal and aesthetic preferences and touches upon the perceived liberties private collectors have through the activity of display as discussed in Chapter Two. These themes were also common to Alison's description of display: 
I collect seven... so there should actually be seven saucers in this stack but I'm worried about the shelf breaking so I only have four so the first one's always the... display piece and there's always six layered at the back and to me that's aesthetically pleasing so it's just seven cups and saucers... I probably feel comfortable collecting twenty of each colour so there are other cupboards with... more in it but for display purposes this works for me (Alison Reid).

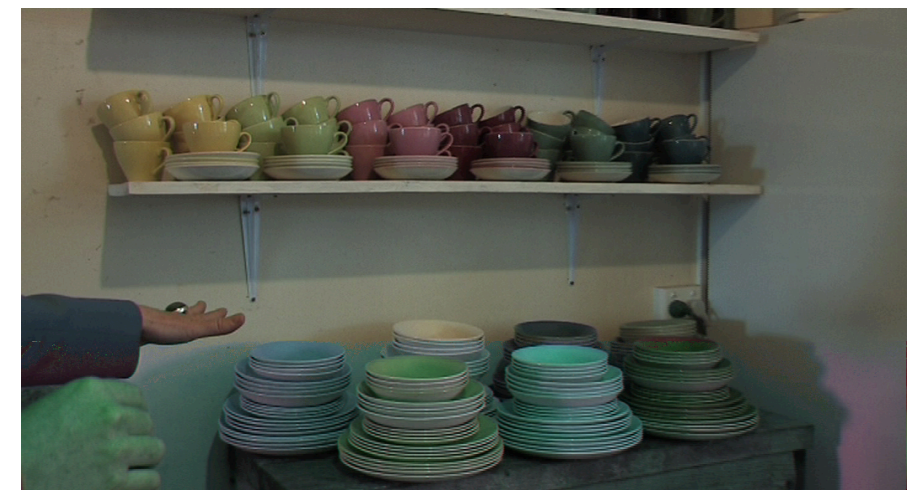

Figure 23. A selection of Alison Reid's Crown Lynn Colour Glaze collection. Frame-grab taken from interview footage captured at Alison Reid's house, Auckland, 17 October 2011.

Displaying their collections in accordance with their own aesthetic sensibilities, the personal choices Alison Reid and Jim Barr made within their own homes were distinct from those curatorial choices others employed when exhibiting their collections in the public domain.

\section{Interpretation}

Sharing his collections publicly at collecting club fairs Peter Smith described the process as follows:

[The Wellington Antique and Bottle Club] invited me to do the National Show which was in Lower Hutt and I tried to learn as much as I could about how to display. You get one point two metres of display space... and...categories so it's got to be glass or New Zealand pottery or china... and from there they said it's pretty much up to you how you'd like to display... so I put on three displays which was a bit much...for me but it involved getting some material and creating a backdrop... writing descriptions... and then just displaying (Peter Smith). 


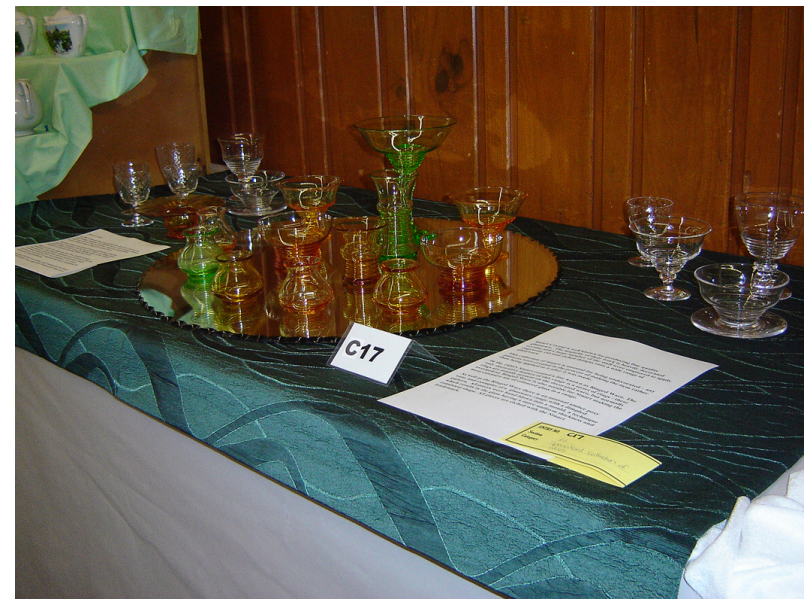

Figure 24. Items from Peter Smith's Stuart Crystal collection as they were exhibited at the National Antique and Bottle Collectables Show in Lower Hutt. Image supplied courtesy of Peter Smith.

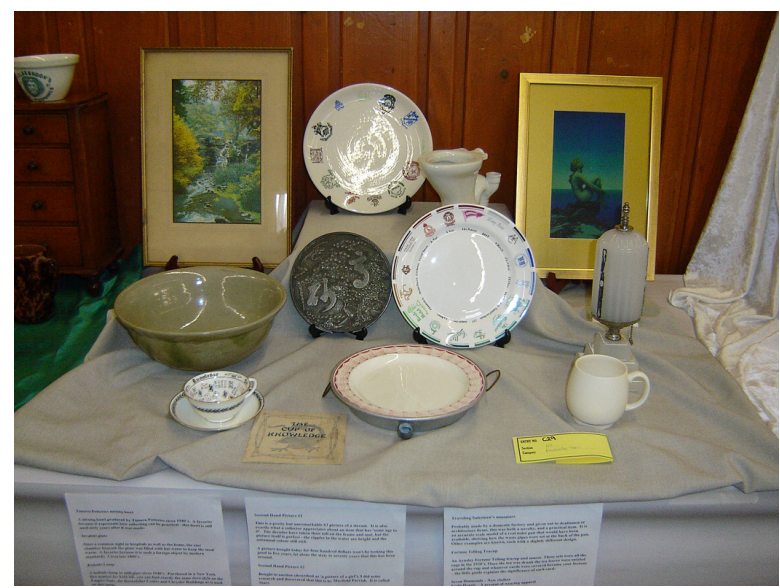

Figure 25. Items from Peter Smith's Crown Lynn collection as they were exhibited at the National Antique and Bottle Collectables Show in Lower Hutt. Image supplied courtesy of Peter Smith.

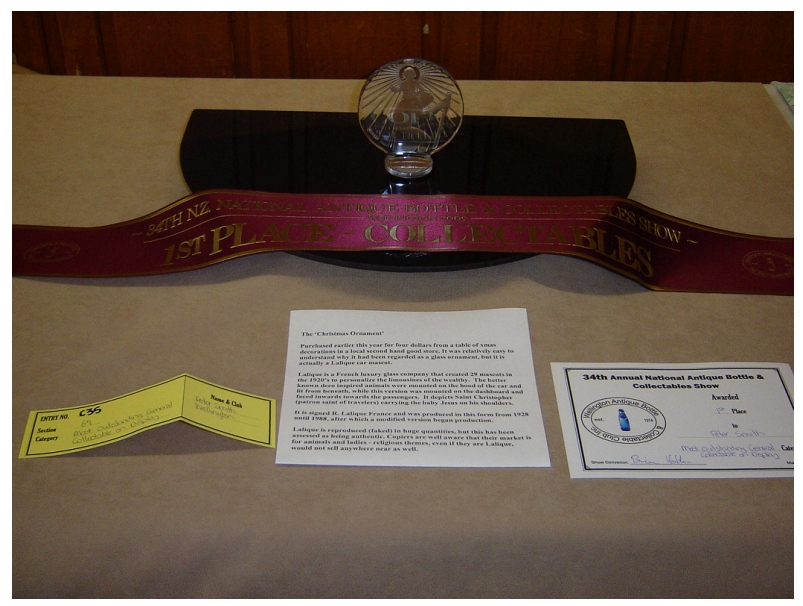

Figure 26. Peter Smith's Lalique hood ornament as it was exhibited at the National Antique and Bottle Collectables Show in Lower Hutt. Image supplied courtesy of Peter Smith. 
Referencing the effort and creativity involved in generating public displays, Peter Smith's description was consistent with that of Ian Ladds - another collector who shared his collections publicly at collecting club days. Apparent in both Peter Smith's and Ian Ladd's descriptions of their display practices as members of collecting clubs, were taxonomic groupings and the incorporation of text, to offer a context to the objects displayed.

The collection I showed you in the...garage was a calcite, a fascinating mineral three hundred and sixty five odd different... crystal shapes available... that was just one simple mineral so you know I could put a display like that up quite easily and all its associated minerals so you might... have... what is it $\mathrm{C} \mathrm{A} \mathrm{C} \mathrm{O} \mathrm{two} \mathrm{or} \mathrm{three...} \mathrm{in} \mathrm{the} \mathrm{middle} \mathrm{of} \mathrm{it} \mathrm{and} \mathrm{have} \mathrm{all} \mathrm{the} \mathrm{different}$ calcites... around it (Ian Ladds).

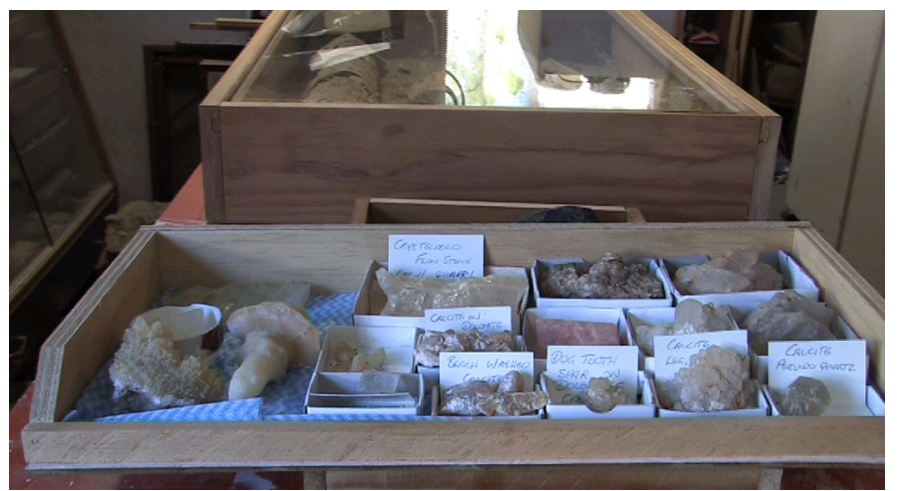

Figure 27. Ian Ladds's calcite collection. Frame-grab taken from interview footage captured in Ian Ladds's residential shed, Nelson, 21 October 2011.

The significance of texts to accompany objects as part of display practices, was also mentioned by John McCosh: 'I think it's pretty important to sort of label things so people know what's going on...like with the possum I've actually got a small text to say they were introduced into New Zealand on such and such a date for the fur trade'. 


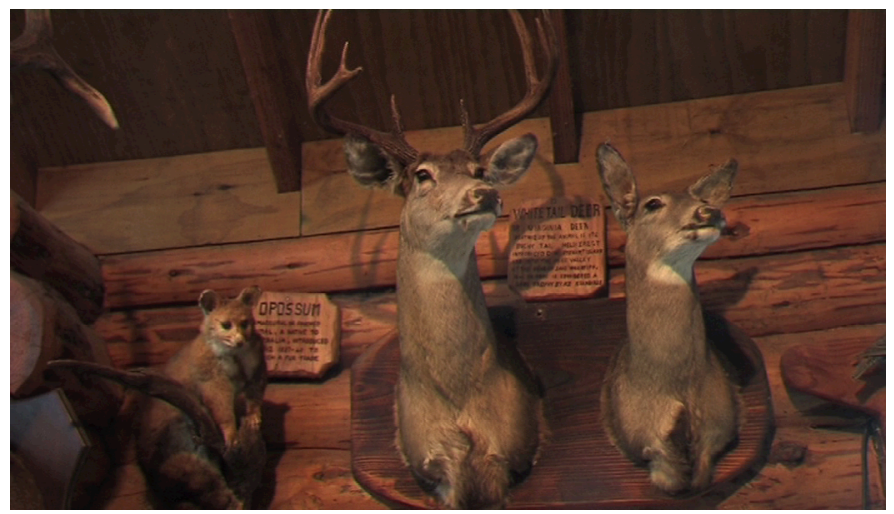

Figure 28. Possum, White Tail deer specimens with labels. Frame-grab taken from interview footage captured at the Kahutara Taxidermy Gallery, Featherston, 07 October 2011.

Jean Hall, explained how visitor feedback to the texts she had produced, encouraged her to continue with this method:

I had an elderly couple come... and she said oh my husband's really enjoying it and I didn't think he had because he'd gone way down the other end and she said he's stone deaf so I had put little labels on it and so he was doing his own wee tour and so I've continued to do that for that reason (Jean Hall).
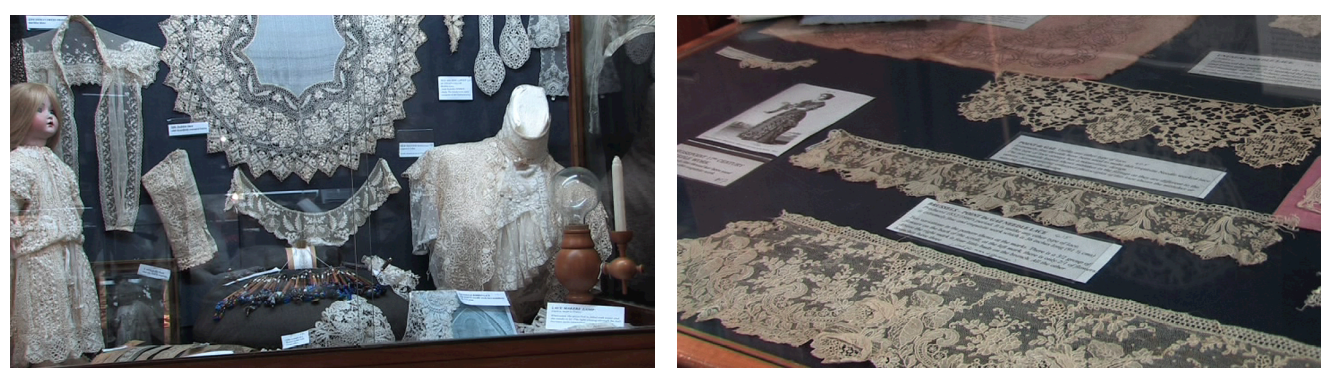

Figure 29-30. Texts accompanying Jean Hall's lace collection. Frame-grabs taken from interview footage captured at Lillia's Lace Museum, Geraldine, 23 October 2011.

Tied to the educational and entertainment values private collectors placed on the activity of sharing their collections publicly, the production of texts and labels were seen as playing an integral part in the display practices of these private collectors. These practices complement those of the publicly funded heritage institution, in accordance with Louise Ravelli's statement that: 'Objects must be interpreted and contextualized, and text has a particularly significant role to play in this' (Ravelli 1996, 369). 


\section{Visitor feedback}

Public reaction influenced Bruce Lyon's display choices:

When I first started I had got the entrance foyer, it was a little desk and a few bits and pieces for sale in there, and the next room was my New Zealand police stuff and then came into this room which was just pretty much everything else. What happened was... that I realized that a large number of people, as in probably half, would stop outside look through the door and go "ugh New Zealand police" and walk away. I understood that... as I heard one lady go one day "ugh I can see them down the street" so I decided to change it a bit. I brought one of the motorcycles I had inside, that's a Italian police Motor Guzzi, brought that in set that up and really just brought a couple of other bits in made it more colourful in that room (Bruce Lyon).

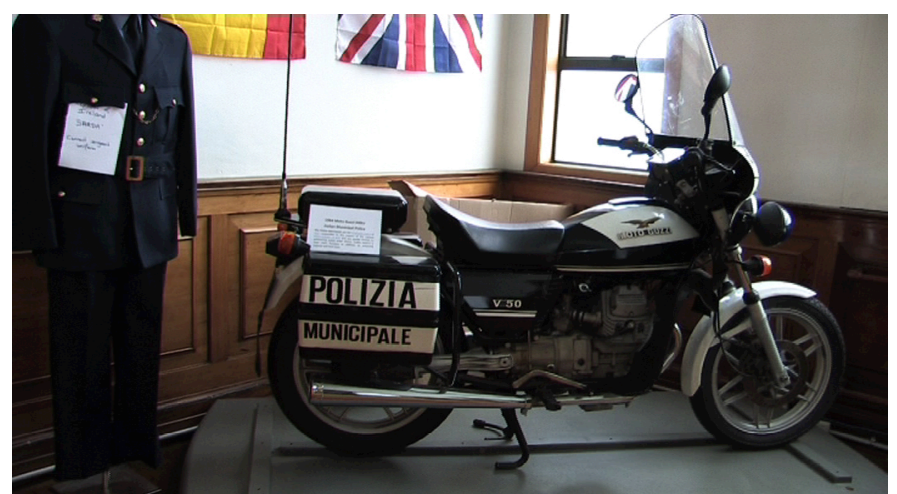

Figure 31. The International Police Museum entrance featuring Bruce Lyon's Motor Guzzi. Framegrab taken from interview footage captured at The International Police Museum, Dannevirke, 28 October 2011.

Reconfiguring the display of his collection in accordance with visitor feedback, Bruce Lyon's display practices reflect the process of informal evaluation. 'Informal evaluation includes such things as providing a visitor's book, observing reactions as people move through your gallery' (Museum of New Zealand Te Papa Tongarewa $2001,15)$. This practice is recommended by heritage sector services such as National Services Te Paerangi - 'Constant evaluation is the best method of refining skill in designing exhibitions' (Museum of New Zealand Te Papa Tongarewa 2001, 15). 


\section{Conservation}

This section examines those activities of the private collector that are aimed at prolonging the existence of their objects. It divides these activities into the preventative conservation and restoration practices of the private collectors with whom I spoke.

\section{Preventative conservation}

The International Council of Museums Committee for Conservation (ICOM-CC) defines preventive conservation as:
All measures and actions aimed at avoiding and minimizing future deterioration or loss. They are carried out within the context or on the surroundings of an item, but more often a group of items, whatever their age and condition. These measures and actions are indirect - they do not interfere with the materials and structures of the items. They do not modify their appearance (International Council of Museums Committee 2008).

In accordance with ICOM-CC's definition this sub-section addresses the conservation practices of private collectors that do not alter the appearance of their objects. In doing so it seeks to convey the storage, environmental conditions, security and handling practices private collectors expressed as influencing their collecting practices.

\section{Storage}

The private collectors with whom I spoke employed various storage solutions. Alison Reid explained that due to limited space constraints, 'I've got the tiniest house in the world', she stored her collection items in a 'secret cupboard' or in her bedroom, which was 'chocka block'. Peter Smith preferred to store his collection items in a storage locker, citing the fact that he purchased the apartment in which he currently lived because it came with one. Peter described how he stored individual items within this locker in 'cardboard and plastic boxes and wrapped in tissue [paper] and bubble wrap' or 'acid free paper if the piece warrants it'. 
Ian Ladds and Jean Hall supplemented the few glass cabinets they owned with purpose built enclosures for their collection items. Ian Ladds built his own wooden cabinets, while Jean Hall framed individual textile exemplars herself.

I normally frame them. I will get the backing and seal it, and wash the fabric to get the dye residue out, and then stretch it on the backboard and hand sew the item on it. Then I put beading in the frame itself to hold the glass in and then I can then screw the lace onto that beading, and I make a little air hole so it does give it some room to breathe. It seems to keep it in its own little igloo (Jean Hall).

Bruce Lyon also relied on a mix of glass cabinets and purpose built enclosures, building shelving units and 'ten mil armoured glass' display cases for police uniforms. John McCosh's storage solution was particularly innovative, a self built log cabin. John hung his own collection from the cabin walls, housing additional collection material in accordance with depositors' wishes. For example, John had built a glass-enclosed corner for parts of the Robertson Bird Collection and stored the rest in the glass display cases in which they came. Fiona Campbell stored some of her collection materials on 'massive walls' in her home, while others resided in an offsite storage locker. Jim Barr's collection was stored in three locations, his home, the Dunedin Public Art Gallery, and at his 'arbitrary opening gallery', which had a storeroom that he described as resembling a 'clumsy version of a museum art store'.

The storage methods employed by these private collectors were influenced by their predilection towards access and display. For example Peter Smith explained that the boxes he purchased to store his collection materials had 'to have wheels because when you're displaying in public you want to put it on the floor of the hall and then roll it to wherever your display is'.

Fiona Campbell described why she believed a wall was the 'best place to store an art work': 'Your wall is definitely your best place to... store something, conservators would say the complete opposite because you know it's going to degrade in the light but what's the damn point of an artwork if it's not you know seen'. Relaying how her perspective differed from that of the heritage institutional professional, Fiona touched 
upon the perceived differences between how a heritage institution concerns itself with the care of collection materials as distinct from how she would. In this respect Fiona's perspective resonated with that of Jim Barr, who described:

I don't mind a painting that changes from green to brown. I don't call for a conservator when that happens. I just think that's an interesting part of the process. But I think that's a luxury of private collecting that you don't necessarily get when you're in an institution (Jim Barr).

Acknowledging that their perspectives are at odds with best practice, in accordance with those standards prescribed by conservators of heritage institutions, these private collectors consciously choose to prioritise access over preservation. A sentiment that was also conveyed by John McCosh:

The [Robertson Collection] is how it should be it's all behind glass so its protected from dust and what have you, my own collection isn't protected from dust...so I've got to sort of clean it all the time. But why it's like that... [is] I like hands on things, like a lot of kids will come along and [I will] say...how would you like to hold a little crocodile...it's a one year old, where if it's behind a case you can't sort of touch...I don't mind... people sort of touching...the animals (John McCosh).

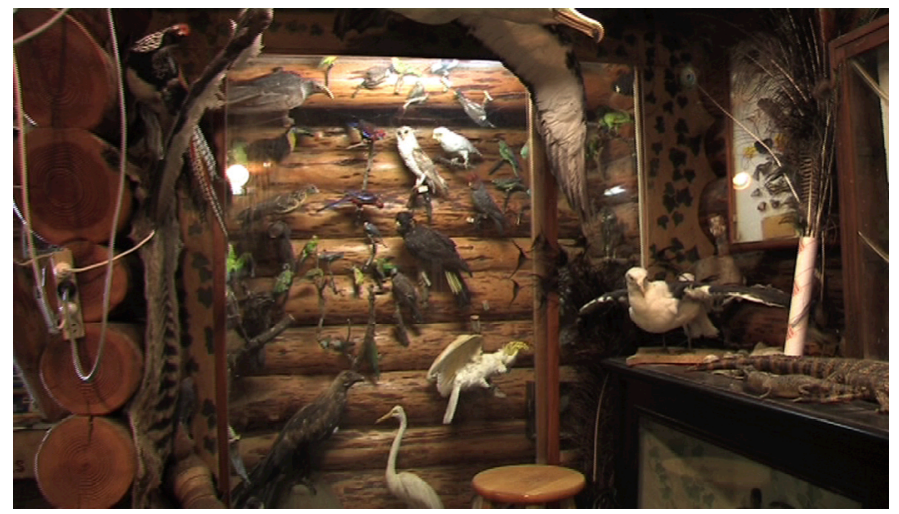

Figure 32. Background - alcove that John McCosh built for the Robertson Bird Collection.

Foreground - John McCosh's collection featuring one-year-old crocodile. Frame-grab taken from interview footage captured at the Kahutara Taxidermy Gallery, Featherston, 07 October 2011. 


\section{Environmental conditions}

Despite John McCosh's admission that his collection was not stored 'as it should' be, data also revealed that he was sensitive to environmental conditions, which could affect his collection materials.

It's very important is to have it in this kind of building because it doesn't get any light. I've got ultra violet glass up there, so there's no natural sunlight...Logs keep a very steady temperature and if you had another purpose built building you'd probably have to have air conditioning (John McCosh).

Jean Hall was also sensitive to the environment in which her collections were displayed: 'I try and be as kind as I can to them. I keep it under the dark all the time and no moths are allowed within cooee of anywhere. We try and keep it the same temperature by insulation'. That these collectors protect their collection materials from environmental conditions such as light, temperature and pests is in keeping with best practice standards (National Services 2001).

\section{Security}

Bruce Lyon and Ian Ladds also touched on the security measures they had taken to protect their collection materials, with both collectors citing their use of locks. Explaining why he stored and displayed his collections as he did, Bruce Lyon said:

When I started to do the collection I decided that security is important for the stuff, partly because you want people to be able to look at it, but you don't want to be standing there beside them the whole time watching what they're doing, so a lot of it is beyond arms reach or locked in cabinets (Bruce Lyon).

Ian Ladds described why he was making a new cabinet as he was, in his statement that: 'this [cabinet] has got a locking arrangement...so all my really good stuff can actually go in the house. If we've got visitors [then] I can show them what we're looking at, but it'll be locked'. 


\section{Handling}

In citing her security reasons as influencing the way in which she stored artworks when they were on the road, Fiona Campbell also explained how her handling philosophies were influenced by preventative conservation considerations.

What's in the trailer is...a whole lot of panels on wheels that the artwork is affixed to. It's affixed well for travel reasons and for security reasons but also we had worked out early on that artworks get damaged when they are hung and unhung, packed and unpacked, so if we could eliminate those four steps by having the works permanently affixed to panels then we [were] going to save a lot of the artwork (Fiona Campbell).

Committed to ensuring the longevity of her collection items, whilst also privileging the practice of display, Fiona further explained how she communicated her handling philosophies to school children:

I'd line them up and say “ok here's the rules, look with your eyes but not with your hands cos these are all unique pieces, if they get busted or broken I can't replace them and that would be sad cos they're unique, which means they're one off. This is not a copy, this is the real thing that the artist has done, spent blood sweat and tears doing and loved doing and wants to share with you", so they understood that (Fiona Campbell).

Through offering a deeper context as to why her collection materials should be handled with care, Fiona's activities highlight the role private collectors can play in disseminating information about the preventive conservation practices with which cultural heritage institutions engage. This benefits not only the care of her collection but of all heritage collections, as the knowledge her public gain from visiting her collection, has the potential to inform their experiences at other heritage institutions. 


\section{Restoration}

ICOM-CC defines restoration as

All actions directly applied to a single and stable item aimed at facilitating its appreciation, understanding and use. These actions are only carried out when the item has lost part of its significance or function through past alteration or deterioration. They are based on respect for the original material. Most often such actions modify the appearance of the item (International Council of Museums Committee 2008).

Two of the private collectors spoken to, Jean Hall and John McCosh, had restored materials. They drew on their specialist knowledge to repair materials that might otherwise have decayed.

Describing the state of a textile souvenir for the Dunedin Exhibition as looking 'like a wet cloth, it was just dripping in holes' Jean Hall explained that she had restored it 'because I knew it was so old that I [was not] likely to get another one'.

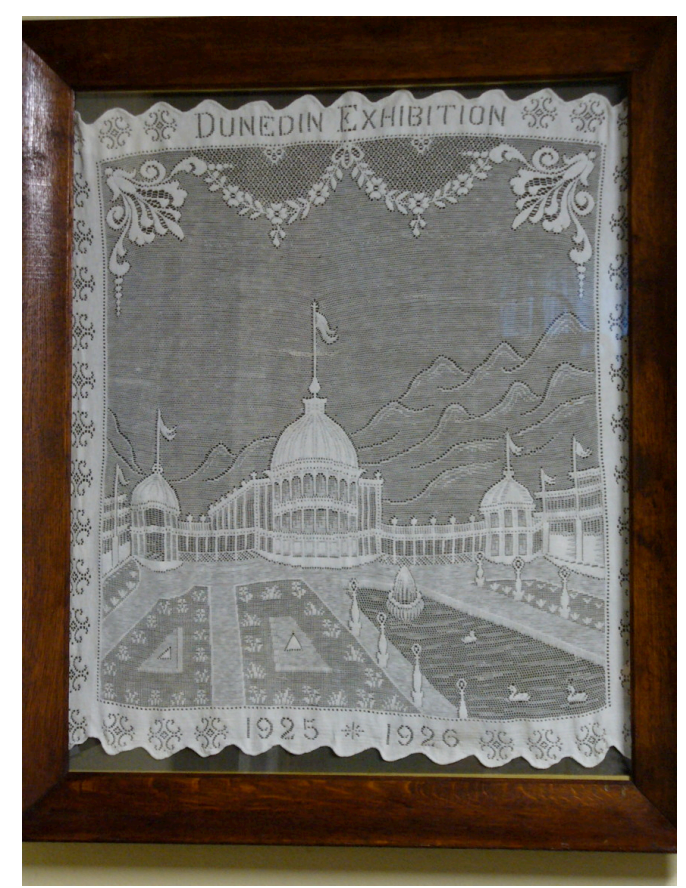

Figure 33. 1925-1926 Dunedin Exhibition souvenir restored by Jean Hall. Image courtesy of Jean Hall. 
John McCosh expressed that he was given a marlin 'in a very poor state...the bill was broken off, it had gone grey', which he 'fixed up' by putting 'the bill back on and repainted it'. He was motivated to do so, because he saw the potential for the Marlin to complement his collection.

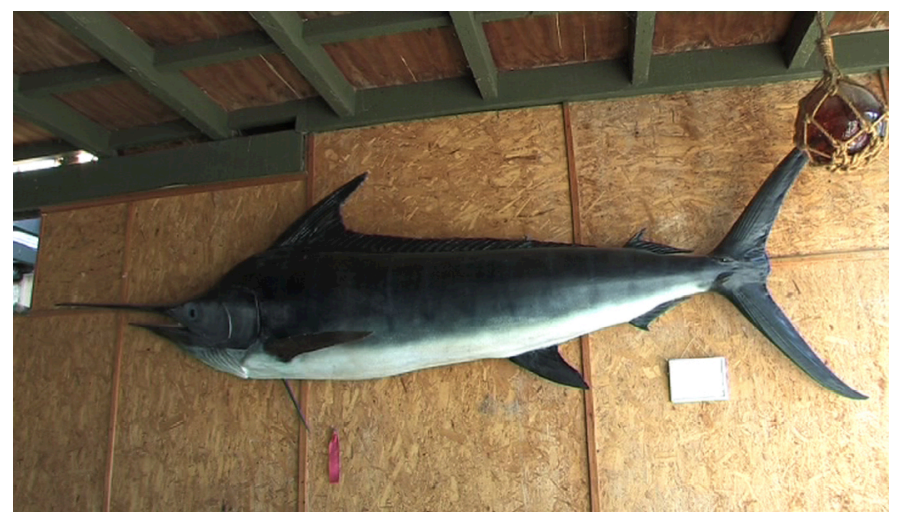

Figure 34. Marlin restored by John McCosh. Frame-grab taken from interview footage captured at the Kahutara Taxidermy Gallery, Featherston, 07 October 2011.

The restoration activities of these collectors benefit not only the private collector through enhancing their collection, but also the item itself, prolonging its life. In accordance with ICOM-CC's definition of restoration, the respect these private collectors articulated as having for these materials unifies their philosophies with those of the heritage sector. The restoration activities of these collectors do however differ from best practice standards because they are not reversible (Ladkin 2004).

\section{The future of private collectors' collections}

Related to the survival of collection materials is an appreciation of what the future of the private collectors' collection materials may hold. I asked collectors what future they envisaged for their collections beyond their life span. Eager to ensure I did not influence their responses in anyway I consciously chose to frame this question without reference to the role heritage institutions could play.

Unable to foresee the long-term future of their collection materials the short-term future of their collections was expressed in terms of what they will do with their collections as they approach the end of their lives. An analysis of these various plans revealed that those collectors who did not view their collections as an entity in and of 
itself - Jim Barr and Peter Smith - or collected materials of high financial worth - Jim Barr and Fiona Campbell - were more open to selling off collection items.

Contrasting the perspectives of these private collectors were those collectors who were averse to selling off their collections - Alison Reid, Bruce Lyon, Jean Hall, John McCosh and Ian Ladds. Two of these collectors - Alison Reid and Bruce Lyon envisaged their collections would go to a private trust. The remaining three collectors - Jean Hall, John McCosh and Ian Ladds - speculated on the role their families might play in deciding the future of their collections.

In contemplating the future of his and his wife's collection Jim Barr said 'we might give nothing away we might sell the whole lot...when that time comes I don't care'. Further explaining the rationale behind this sentiment in his statement that 'we've never thought that we're building up some magical combination that should be kept for posterity to look at and admire our taste or anything'.

Fiona Campbell also envisaged that she would sell her collection:

Eventually I will start selling... and I've got on my mind that one day I'm going to be a little old lady, with a little old cottage, and eventually I will have to have a little collection... I've got a really large house....in Wanaka, I'll probably have that for about ten years but by then my littlest will be eighteen.... and at that stage I'll probably sell most of everything and go real small in my life...so...I see a big change for my collection at that stage. I am secretly hoping to make some money out of it that would be really nice to actually have a...small but rewarding financial hit for... backing some...early career artists (Fiona Campbell).

Peter Smith explained 'I've got a lot braver about selling it. I've just got to move it on to somebody else you know I've enjoyed it for a period of time and someone else can'. Peter further explained in a follow up email that:

While I own these items they are looked after, and that's all I would hope for them after I die ...I struggle with the idea of making a bequest to an institution like Te Papa because I don't particularly like how they present exhibits, I 
know there's piles of stuff in storage and what is on display doesn't really seem like much. But I have looked at the Pelorus Trust which has the Crown Lynn archives and artifacts, and the Auckland War Museum which uses more classic display techniques; there always seems to be a lot more to look at (and a lot more information too) - I actually really like the idea of my items ending up in the Auckland Museum, that would be very flattering....All of this, I should point out, would only be relevant if I had time to make the arrangements before my demise. Until then I'll be removing and adding (possibly even discontinuing) my collecting and collections - I can't even envisage what items my collections would consist of at the point of my death, it really depends on what I discover or lose interest in (Peter Smith email to author April 12, 2012).

Peter Smith's email suggests that while the future of his collections is a relative unknown, he does have strong feelings about the role heritage institutions might play in the future of his collections. His statements reveal that his experiences visiting heritage institutions have a direct influence on those who he would consider depositing with. He views Auckland Museum's collecting practices as more closely aligned with his personal tastes, thus affording them a degree of symbolic capital that he does not afford The Museum of New Zealand Te Papa Tongarewa.

Alison Reid envisaged that her collection would go to a private trust: 'When I pass away my pieces will probably be... donated to the Portage [Ceramics] Trust'. The Portage Ceramics Trust to which Alison refers was founded in 2005, its original role was to 'secure one of the most significant Crown Lynn collections' amassed by a private collector 'yet to be offered for public sale' (Molyneaux 2010, 35). Now secured the trust busies itself with the cataloguing and preservation of this collection. It receives funding and support from The Trusts Charitable Foundation, The ASB Community Trust, Lottery Grants Board Lottery Environment \& Heritage Distribution Committee and The Waitakere City Council (Molyneaux 2010). The Trust has a board of 'well-respected museum and heritage professionals' and in 2008 hired three staff "whose experience included working with industrial and social history collections, archives and working at Crown Lynn as an employee'(Molyneaux 
2010, 36).

Bruce Lyon also discussed the role a trust might play in his collection:

[I] may all drop it into a trust and that could continue on, and that would be a nice way of doing it because yeah it has a dollar value, but to get that dollar value you have to sell it off bit by bit and ... it's not so much the dollar value, it's the fun of it, and so to me it makes sense if it can continue on for whenever and that just requires someone to take it over in due course (Bruce Lyon).

Jean Hall saw the future of her collection as 'for the family to decide', while John McCosh balanced his desire to see 'one of my children to take it over' with the understanding that this was unlikely to occur: 'None of my kids are interested... so [we are] even sort of thinking...do we put it on the market now and sort of sell it but oh I wouldn't like to...you don't know what will happen around the corner'. John McCosh's lack of family interest was similar to the perspective proffered by Ian Ladds:

I'll have to consider whether... the family gets it... but I...don't want to just give it to them because they're family, that's pointless, all they will do is sell it off if they're not interested... Some might say that that's their right... my argument is that I've spent forty or fifty years, or if I get a good life sixty years, of collecting it up [and] I'd like to see it used wisely (Ian Ladds).

Unlike publicly funded heritage institutions that presuppose that their activities will occur in perpetuity, the private collectors I spoke to were aware that the long-term future of their collection materials was beyond their control. Despite the private collectors' uncertainty regarding the future of their collections it was observed that common to all, was a sense that their collection items would remain in the hands of private individuals. In many ways this supports Anthony Shelton's observation that there is a physical segregation between the private collector and the heritage institution: 
Indeed, the intellectual gulf that distinguishes between institutions and individuals sometimes mirrors an attempted physical segregation: one which may lead collectors to feel that their presence is unwanted in some of the museums that have benefited from either their own generosity or that of their forbears (Shelton 2001, 11).

References to heritage institutions remain largely absent in the private collectors' future plans for their collections. This amplifies the private collectors' distance from publicly funded heritage institutions within the heritage sector. Perhaps, as described in Peter Smith's aversion to depositing with The Museum of New Zealand Te Papa Tongarewa, private collectors are unwilling to offer their collections to heritage institutions because they perceive that the objects they collect would not be displayed in accordance with their personal tastes. For whatever reason they choose not to deposit their collections with heritage institutions, the fact that private collectors envisage their collections will remain in private hands, suggests that private individuals will continue to play a role in the future of their collection materials.

\section{Summary}

In distinguishing between the collecting practices of the publicly funded museum and the private collector Stephen Weil states:

Museum collecting today, for all these reasons - the burden of caring for collections, the necessity to negotiate a labyrinth of legal considerations, and the need for acquisitions to be carefully related to mission - has become something else. Still exciting, still rewarding, but - to a great degree - it is stately, sober and deliberate as well. It is said that blondes have more fun. So too, I think - and it's a rueful thought - do private collectors (Weil 2002, 150).

The findings reproduced in this chapter suggest that while private collectors do have fun, their collecting practices are also deliberate. A product of interactional effects between non-human materials and humans, the collecting practices of private collectors may also be seen as a manifestation of their individual agency. This agency reflects the collecting activities of the private collector as those of one person. This 
contrasts the activities of the heritage institution whose activities reflect those of many individuals and are bound by policies that seek to govern them in accordance with formalized missions and best practice standards. This finding supports the differentiation of private individuals from heritage institution staff based on work processes as suggested by Meyer (2008).

An analysis of the private collectors' collecting practices reveals that they are generally consistent with the collection, display and preservation activities of heritage institutions. The private collectors' commitment to the practices of preservation and display refutes the criticism that private collectors are incapable of caring for and providing public access to collections (Lucas 1896; Knell 2004). What distinguishes the private collectors' collecting practices from heritage institutions however is the personal relationship they have to the objects they collect, their autonomy over their collecting practices, and their propensity to privilege the activity of display over that of preservation. These factors, it is suggested, cause private collectors to adhere to some heritage sector best practice standards whilst diverging from others.

Private collectors are aware of their own mortality, as discussed in their descriptions of the long-term plans of their collections. This awareness leads them to concede that the future of their collections is beyond their control. This contrasts with the heritage institution, whose activities are considered to occur in perpetuity. Findings showed that private collectors largely see the future of their collections as remaining in private ownership, with one collector suggesting he would be open to depositing with a heritage institution that displayed objects in a manner that was consistent with his own subjective tastes. The limited reference to heritage institutions in the future collection plans of these private collectors suggests that the relations between private collectors and heritage institutions within the heritage sector are not currently healthy. It signals the need for additional work to be done if there are to be 'successful' partnerships between private collectors and heritage institutions within the heritage sector as advocated for by Hagan (2011).

This discussion of the relationship between the private collector and heritage institutions is furthered in the Conclusion. It seeks to explore these findings in relation to those of the previous chapter. In doing so it explores how the perceptions and 
practices of the private collector who shares their collections publicly position them in relation to the heritage sector. 


\section{Conclusion}

This thesis has explored the perceptions and collecting practices of private collectors who share their collections publicly. It has done so with the intention of positioning these collectors in relation to the heritage sector. The impetus for this research stemmed from a professional interest in private collectors who share their collections publicly. This inspired my academic interest in seeking out literature that focussed on private collectors and the heritage sector, as discussed in Chapter One.

The literature reviewed showed that there are points of commonality and difference between private collectors and publicly funded heritage institutions such as the public museum. It identified how evaluative judgements around collecting blurred the boundaries between private collectors who share their collections publicly and publicly funded heritage institutions. It exposed the absence of literature that addressed the private collectors' position in relation to the heritage sector from their perspective, and showed the need for research into the perspectives of a diverse range of collectors. This gap provided the framework for this research.

The limitations of my research design were discussed in Chapter One. They included the small sample size, the use of audio-visual recording to capture data, and the archiving of data. I believe the limitations of these choices were outweighed by their benefits. The small sample size meant I was able to capture in-depth data. The use of audio-visual recordings allowed me to consider observational data in relation to verbal data. This offered a deeper context to the verbal data captured and allowed me to examine the accuracy of my findings through comparing the two data sources. The archiving of this data was in keeping with the exploratory nature of this research, and has created a rich resource for others to consult.

This study has concerned itself with the perspectives of private collectors who share their collections publicly. Its value lies in its preoccupation with exploring the position of the private collector in relation to the heritage sector from the private collector's perspective. Privileging the perspectives of the private collectors with whom I spoke, I balanced them with observations I conducted in the field. I synthesized the data each method produced by drawing on heritage sector literature 
that discussed values and best practice standards, as well as theories of agency found in the work of Bourdieu, Stebbins and actor-network theorists.

My first objective was to explore how private collectors perceive of the heritage sector and their relationship to it. This objective was explored through an examination of the private collectors' perceptions of heritage institutions within the heritage sector, in Chapter Two. Findings showed that the private collectors with whom I spoke were unsatisfied with the services that heritage institutions provide. This was manifested in the private collectors' expression of personal taste regarding the display of particular objects within heritage institutions. It was found that their tastes were a product of their habitus and cultural capital, and as such it was suggested that the cultural capital of private collectors caused them to identify perceived inadequacies of heritage institution services in accordance with their own tastes. Findings also showed that not all private collectors are enamoured by the symbolic capital of heritage institutions, challenging the suggestion that private collectors were primarily motivated to collaborate with heritage institutions because they wished to enhance their status. It was revealed that private collectors acknowledge the existence of 'professionals' in the heritage sector, refuting Stebbins's (2007) suggestion that private collectors have no professional counterparts. A closer examination of the private collectors' perceptions of these professionals revealed that they distinguish their collecting activities from them on the basis of the professionals' specialist skills and the perceived autonomy they have over their collecting activities.

This led to a discussion of my findings in relation to my second research question: what values (private / public / institutional) motivate private collectors to share their collections publicly? These findings showed that some private collectors are personally motivated to share their collections publicly because of the personal commitment they have to the objects they collect and to their creators/manufacturers. The education and entertainment of others provided further motive for private collectors to share their collections. These values were identified as unifying the ethos of the private collector with the public they serve. It was also found that the significance private collectors place on the activity of display aligned the ethos of the private collector with heritage institutions within the heritage sector. This finding showed that private collectors and heritage institutions both view the practice of 
display as a vehicle by which value can be communicated to others. This perspective resonates with Pearce's diagram 'Collecting in relation to perceived valuation' (Figure 2.). The sense of public responsibility private collectors associate with the practice of display further aligns their ethos with that of the publicly funded museum. It was suggested that the personal values of the private collector are informed by wider cultural understandings, consistent with the theories of Richins (1994) and Morrison (2010).

This thesis also sought to examine what the collecting practices (acquisition, storage, cataloguing, display) of the private collector entail, and how these related to institutional collecting practices within the heritage sector. The findings to this research question were presented in Chapter Three. In this chapter I explored the relationship private collectors had with the objects they collect and with other people in their environment. Best practice standards and values found in heritage sector literature were adopted to provide a framework in which to better understand the collecting practices of private collectors relative to the publicly funded heritage institutions.

This analysis revealed that, while some of the practices private collectors employed were consistent with best practice standards, others were not. It attributed these differences in practice to the activities of the private collector reflecting those of an individual (versus those of many individuals), as well as the private collector's predilection to privilege the practice of display over that of preservation. Findings also suggested that the emphasis private collectors place on the practice of display determined their approach to other collecting practices.

Private collectors acquire collection materials from a variety of sources. They do so for various reasons - some private collectors were motivated to acquire materials because of the historical value they place on the objects they collect, others for their objects' educational and scientific value. These values are synonymous with those of publicly funded heritage institutions, as espoused in heritage sector literature such as Significance 2.0 (Russell and Winkworth 2009). It was found that the private collectors with whom I spoke were not primarily motivated to acquire collection materials for financial gain, with a number of the collectors viewing the financial 
worth of their collections as an ethical obstacle to overcome. This challenges the perception of the private collector as 'avaricious' hoarder (Sax 1999, 61). It was observed that the acquisition practices of private collectors differ from best practice in that they are not formally documented. It was suggested that their choice not to document their acquisition practices was a reflection of the autonomy private collectors have over their collecting practices as individuals. This distinguishes the private collector from the heritage institution whose institutional policies govern the collecting activities of many individuals to fulfil their obligations to stakeholders.

Findings showed that private collectors store their collections in various ways. The decisions regarding how they housed their collection materials were influenced by their preventative conservation philosophies regarding environmental conditions, security measures and handling considerations. These philosophies indicated that private collectors were committed to the preservation of collection items and that their preventative conservation practices were cognisant of factors that best practice standards concern themselves with. This refutes the claim that private collectors do not care for their collections (Lucas 1896; Knell 2004). It was observed that two of the private collectors use their specialist knowledge to restore materials, ensuring the longevity of items that might otherwise decay. Findings ultimately suggest that the storage practices private collectors employed are influenced by the priority they place on access and display. This led me to conclude that the private collector's adherence to best practice preservation standards is in part influenced by their desire to display collection materials.

It was observed that while some private collectors catalogued their collection materials, others chose not to. Those who have worked in heritage institutions or placed historical significance on the objects they collect were more inclined to catalogue collections. Those that had a small collection, found their collection items in the field, or actively produced the majority of objects in their collection did not. It was found that collectors who did not catalogue collection materials did so in the understanding that this was not best practice. This finding suggested that while collectors are aware of best practice standards, some consciously choose not to follow them in accordance with their own subjective tastes. 
It was found that the display methods employed by private collectors were influenced by the following factors - physical space, selection, interpretation, and visitor feedback. The commitment some private collectors expressed as having to the practice of interpretation and evaluation in accordance with visitor feedback suggested that the display practices of private collectors could also reflect best practice standards prescribed by heritage institutions. This finding challenges the claim that private collectors are not capable of providing public access to their collections (Lucas 1896; Knell 2004).

In discussing what future the private collectors with whom I spoke envisaged for their collections, I explored findings to my fourth research question. These findings showed that those collectors who did not see their collection as an entity in and of itself, and those collectors of items of high financial worth were open to selling collection items. Findings also showed that many of the private collectors with whom I spoke were unwilling to sell their collections items. These collectors envisaged that their collections would end up in a private trust or in the care of their families. It was suggested that the limited reference to heritage institutions was indicative of the divide between the private collector and publicly funded heritage institutions within the heritage sector. This divide complicates the potential for 'successful' and 'healthy' partnerships between private collectors and publicly funded heritage institutions as advocated for by Hagan (2011).

Findings from one collector, who did reference heritage institutions, showed his consideration of heritage institutions was influenced by his experiences as an audience member. This link between the willingness of private collectors to deposit with heritage institutions and their experiences as audience members warrants further research. Research into why private collectors choose to deposit, or not to deposit, with publicly funded heritage institutions would benefit the heritage sector by providing a better understanding of the private collector's perceptions of heritage institutions and their purpose. This is important not only because these collectors form part of the audience that publicly funded heritage institutions are mandated to serve, but because of the ramifications regarding the future of heritage institutions that rely on deposits from others. 
The private collector amasses, stores and displays collections just as heritage institutions do, but their practices differ from publicly funded heritage institutions best practise standards because they are those of a private individual who privileges display. Publicly funded heritage institutions are right then to identify the activities of private collectors as different, but not on the grounds they do not care for the objects they collect (Knell 2004), or are not interested in the public's welfare (Lucas 1896). Private collectors are distinct from publicly funded heritage institutions because they do not perceive that their subjective tastes are reflected in them. They have a personal connection to the objects they collect and this connection leads them to share their collections with others. This connection also leads them to distance themselves from the activities of the publicly funded heritage institutions within the heritage sector, perceiving their activities as offering an alternative to them.

Despite the eagerness of both parties - the publicly funded heritage institution and the private collector - to see themselves as distinct, the findings produced in this thesis suggest that there are commonalities. These commonalities can be used to position the private collector within the heritage sector. This suggests that additional research into how the perceptions and practices of private collectors mirror or differ from other public and private heritage institutions within the heritage sector would be beneficial. This research could further assist in positioning private collectors within the heritage sector based on their similarity and difference to specific institutions. This understanding could also be used to inform collaborative relationships between the private collector and publicly funded heritage institutions.

Further research would also be advantageous because of my small sample size. Reproducing this study on a larger scale could test the findings reproduced here. This research could also see if there were further distinctions or commonalities to be found in the perspectives of private collectors of different media. In addition to these research suggestions I believe it is necessary to compare their perspectives with those collectors who do not share their collections publicly. The advantage of this research would be its potential to further understand the ethos of the private collector. If we are to honestly discuss private collectors then we must not treat them as a homogenous mass, without evidence that allows us to do so. This requires further qualitative research. 
I conclude this thesis with a quote from Joseph Sax, which reads:

The collector has a very peculiar position in society. He or she is crucial to the protection of objects that are of great importance to a community of national, or even global scope. The collector possesses, owns, and has control of these objects, and yet has no public or official position, and no formal responsibility for their care and protection. Moreover, a primary value of the collector is the very presence of individual and eccentric, often advanced tastes that would never be reflected in (indeed is all too often rejected by) official canons of selection and propriety (Sax 1999, 60).

Whilst this thesis supports Sax's perspective it also expands on it by suggesting that a primary value of the private collector who shares their collections publicly is their commitment to the objects they collect and the facilitation of public access to them. It is their difference from and similarity to heritage institutions within the heritage sector that places them in a distinctive position. This position facilitates their ability to offer a unique service to the public. They offer us the chance to touch a one-year-old crocodile (John McCosh), to see fine art in rural areas way from public galleries (Fiona Campbell) and to better understand our manufacturing history (Alison Reid, Peter Smith). They provide an insight into the activities of national and international police (Bruce Lyon), access to fossils and minerals from the Nelson region (Ian Ladds), the ability to see works in institutions that adhere to the artist's intent (Jim Barr), and an insight into the significance of overlooked art forms (Jean Hall). 


\section{References}

Barbour, Rosaline. 2008. "13 New Challenges and Perennial Dilemmas.” In Introducing Qualitative Research, London: SAGE Publications Ltd. Accessed May 05, 2011. http://srmo.sagepub.com/view/introducing-qualitativeresearch/d18.xml

Barr, Jim. 2011. Interview by author. Digital video recording. Wellington, New Zealand, October 03, 2011. The New Zealand Film Archive Ngā Kaitiaki O Ngā Taonga Whitiāhua.

Belk, Russell W. 1995. Collecting in a Consumer Society. London; New York: Routledge.

Belk, Russell, Melanie Wallendorf, John Sherry, Morris Holbrook, and Scott Roberts. 1988. "Collectors and collecting." Advances in Consumer Research 15:548553.

Bennett, Tony. 1995. The Birth of the Museum: History, Theory, and Politics. London: Routledge.

Bourdieu, Pierre. 1984. Distinction: A Social Critique of the Judgement of Taste. Translated by Richard Nice. Cambridge, Massachusetts: Harvard University Press.

Bourdieu Pierre, and Loïc J. D. Wacquant. 1992. An Invitation to Reflexive Sociology. Chicago: University of Chicago Press.

Bourdieu, Pierre. 1993. The Field of Cultural Production: Essays on Art and Literature. Edited by Randall Johnson. Cambridge: Polity Press.

Boylan, Patrick J. 2006. “The Museum Profession.” In A Companion to Museum Studies, edited by Sharon Macdonald, 415-430. Malden; Oxford; Victoria: Blackwell Publishing Ltd. 
Byrne, Sarah, Anne Clarke, Rodney Harrison, and Robin Torrence. 2011. "Networks, Agents and Objects: Frameworks for Unpacking Museum Collections”. In Unpacking the Collection: Networks of Material and Social Agency in the Museum, edited by Sarah Byrne, Anne Clarke, Rodney Harrison, and Robin Torrence, 3-26. New York: Springer.

Campbell, Fiona. 2011. Interview by author. Digital video recording. Wellington, New Zealand, October 05, 2011. The New Zealand Film Archive Ngā Kaitiaki O Ngā Taonga Whitiāhua.

Cameron, Duncan F. 2004. "The Museum, a Temple or Forum.” In Reinventing the Museum: Historical and Contemporary Perspectives on the Paradigm Shift, edited by Gail Anderson, 61-73. California: AltaMira Press.

Clifford, James. 1988. The Predicament of Culture Twentieth-Century Ethnography, Literature, and Art. Cambridge: Harvard University Press.

Controller and Auditor General, Tumuaki o te Mana Arotake. 2006. "Management of Heritage Collections in Local Museums and Art Galleries." Wellington: Office of the Auditor General. Accessed June 23, 2011. http://www.oag.govt.nz/2006/heritage/part2.htm

Csikszentmihayli, Mihaly, and Eugene Rochberg-Halton.1981. The Meaning of Things: Domestic Symbols and the Self. Cambridge: Cambridge University Press.

Cultural Philanthropy Taskforce. 2010. "Growing the pie: Increasing the level of Cultural Philanthropy in Aotearoa New Zealand." Report of the Cultural Philanthropy Taskforce to the Minister for Arts, Culture and Heritage Hon Christopher Finlayson. Accessed February 10, 2012. http://www.mch.govt.nz/research-publications/publications/ministryreports/cultural-philanthrophy 
Dannefer, Dale. 1980. "Rationality and Passion in Private Experience: Modern Consciousness and the Social World of Old Car Collectors." Social Problems 27 (4): 392- 412.

Edson, Gary, and David Dean. 1994. The Handbook for Museums. London: Routledge.

Erickson, Frederick. 2011. "Uses of Video in Social Research: A Brief History." International Journal of Social Research Methodology 14 (3): 179-189. Accessed May 12, 2011. doi: 10.1080/13645579.2011.563615

Evans, Rose. 2002. "Constructing Identity: Collecting Oceanic Art / Artefacts in New Zealand". Master's thesis, Massey University, Palmerston North.

Fahy, Anne. 1995. Collections Management. London: Routledge.

Faugier, Jean, and Mary Sargeant. 1997. "Sampling Hard to Reach Populations." Journal of Advanced Nursing 26:790-797.

Felstead, Alan, Nick Jewson, and Sally Walters. 2004. "Images, Interviews and Interpretations: Making Connections in Visual Research." In Seeing is Believing? Approaches to Visual Research, edited by Christopher Pole, 105122. Amsterdam; San Diego; Langford; London: Elsevier Ltd.

Flick, Uwe. 2007. "Standards, Criteria, Checklists and Guidelines.” In Managing Quality in Qualitative Research, edited by Uwe Flick. London: SAGE. Publications, Ltd. Accessed July 17, 2011. http://srmodev.ifactory.com/view/managing-quality-in-qualitative-research/n2.xml.

Francis, Robin. 1996. "The People's Show: A Critical Analysis.” Journal of Conservation and Museum Studies. Accessed June 01, 2011. http://www.jcmsjournal.com/article/view/jcms.1963/3 
Fyfe, Gordon. 2000. Art, Power and Modernity: English Art Institutions, 1750-1950. London; New York: Leicester University Press.

Gauteng Provincial Government, Department of Sport, Arts, Culture and Recreation. 2008. Gauteng Mapping Report: An Analysis of Gauteng's Creative Industries, edited by AMERU, Wits University, and Culture, Arts and Jobs in collaboration with British Council. Accessed May 05, 2012. http://freedownload.is/pdf/gautengs-creative-industries-an-analysis9767862.html

Grenfell, Michael, and Cheryl Hardy. 2007. Art Rules: Pierre Bourdieu and the Visual Arts. Oxford; New York: Berg.

GNS Science Te Pû Ao. 2012. "Home GNS.” Accessed March 01, 2012. http://gns.cri.nz/

Hagan, Ariel. 2011. "Public Duty and Private Pursuits: Reconciling $21^{\text {st }}$ Century Relationships between Art Museums and Private Collectors." Master's thesis, University of Colorado. Accessed March 22, 2012. http://search.proquest.com/docview/873459413?accountid=14782

Hall, Jean. 2011. Interview by author. Digital video recording. Geraldine, New Zealand, October 23, 2011. The New Zealand Film Archive Ngā Kaitiaki O Ngā Taonga Whitiāhua.

Hancock, Beverly, Elizabeth Ockleford, and Kate Windridge. 2009. An Introduction to Qualitative Research. East Midlands: National Institute for Health Research.

Harrison, Julia D. 1993. "Ideas of Museums in the 1990s." Museum Management and Curatorship 13:160-176.

Heath, Christian, Jon Hindmarsh, and Paul Luff. 2010. Video in Qualitative Research: Analysing Social Interaction in Everyday Life. Los Angeles: Sage. 
Hedstrom, Margaret, and John Leslie King. 2003. On the LAM: Library, Archive and Museum Collections in the Creation and Maintenance of Knowledge Communities. Accessed May 12, 2011. http://jlking.people.si.umich.edu/OECD-LAM-published.pdf

Hooper-Greenhill, Eilean 1989. "The Museum in the Disciplinary Society.” Museum Studies in Material Culture. Accessed May 20, 2011. http://www.depts.ttu.edu/museumttu/CFASWebsite/5326\%20Folder/5326_Re ad/Museums\%20in\%20Disciplinary.pdf

Hunt, Majorie. 2003. The Smithsonian Folklife and Oral History Interviewing Guide. Washington: Smithsonian Institution Center for Folklife and Cultural Heritage. Accessed July 20, 2011. www.folklife.si.edu/resources/pdf/interviewingguide.pdf

International Council of Museums. 2006. ICOM Code of Ethics for Museums. Paris: International Council of Museums Maison de l'UNESCO. Accessed February $02,2012$. http://icom.museum/fileadmin/user_upload/pdf/Codes/code2006_eng.pdf

International Council of Museums. 2009. Key Concepts in Museology, edited by André Desvallées and François Mariesse, Musée Royal de Mariemont, ICOM International Committee for Museology. Translated by Susan Nash. Paris: Armand Colin. Accessed May 20, 2011. http://icom.museum/what-wedo/professional-standards/key-concepts-of-museology.html

International Council of Museums Committee for Conservation. 2008. "What is Conservation? Terminology to characterize the conservation of tangible cultural heritage." Accessed March 01, 2012. http://www.icomcc.org/242/about-icom-cc/what-is-conservation/

Johnson, Randall.1993. "Editor's Introduction: Pierre Bourdieu on Art, Literature and Culture." In The Field of Cultural Production: Essays on Art and Literature, edited by Randall Johnson, 1-25. Cambridge: Polity Press. 
Kell, Patricia. 2004. "The Ashmolean Museum: A Case Study of Eighteenth Century Collecting." In Museums and the Future of Collecting, edited by Simon J. Knell, 72-84. Aldershot, Hampshire, Great Britain; Burlington, Vermont: Ashgate.

Knell, Simon. J. 1994. Care of Collections. London: Routledge.

Knell, Simon J. 2004. “Altered Values: Searching For a New Collecting.” In Museums and the Future of Collecting, edited by Simon J. Knell, 1-46. Aldershot, Hampshire, Great Britain; Burlington, Vermont: Ashgate.

Labrum, Bronwyn, and Conal McCarthy. 2005. "Museum studies and museums: Bringing together theory and practice." Te Ara Journal of Museums Aotearoa 30 (2): 4-11.

Ladds, Ian. 2011. Interview by author. Digital video recording. Nelson, New Zealand, October 21, 2011. The New Zealand Film Archive Ngā Kaitiaki O Ngā Taonga Whitiāhua.

Ladkin, Nicola. 2004. “Collections Management." In Running a Museum: A Practical Handbook, edited by Patrick J. Boylan, 17-30. Paris: International Council of Museums.

Latour, Bruno. 2005 Reassembling the Social: An Introduction to Actor-NetworkTheory. New York: Oxford University Press.

Law, John. 1992. "Notes on the Theory of the Actor Network: Ordering, Strategy and Heterogeneity.” Lancaster: Centre for Science Studies, Lancaster University. Accessed November 12, 2011. http://www.comp.lancs.ac.uk/sociology/papers/Law-Notes-on-ANT.pdf

Lewis, Geoffrey. 2004. "The Role of Museums and the Professional Code of Ethics." In Running a Museum: A Practical Handbook, edited by Patrick J. Boylan, 116. Paris: International Council of Museums. 
Lord, Barry, and Gail Dexter Lord. 1997. The Manual of Museum Management. Walnut Creek, California: Altmira Press.

Lucas, F. A. 1896. "Does the Private Collector Make the Best Museum Administrator?" Science 3 (60): 289. Accessed June 15, 2011. http://www.sciencemag.org/content/3/60/289.2.full.pdf

Lyon, Bruce. 2011. Interview by author. Digital video recording. Dannevirke, New Zealand, October 28, 2011. The New Zealand Film Archive Ngā Kaitiaki O Ngā Taonga Whitiāhua.

Macdonald, Sharon. 2006. "Collecting Practices.” In A Companion to Museum Studies, edited by Sharon Macdonald, 81-97. Oxford; Malden MA: Blackwell.

Macleod, Suzanne. 2001. "Making Museum Studies: Training, Education, Research and Practice." Museum Management and Curatorship 19 (1): 51-61. Accessed April 16 2012. http://dx.doi.org/10.1080/09647770100501901

Martin, Paul. 1999. Popular Collecting and the Everyday Self: The Reinvention of Museums? London: Leicester University Press.

Maykut, Pamela, and Richard Morehouse. 1994. "Qualitative Data Analysis: Using the Constant Comparative Method." In Beginning Qualitative Research: A Philosophic and Practical Guide, 126-149. London: The Falmer Group.

McCosh, John. 2011. Interview by author. Digital video recording. Featherston, New Zealand, October 07, 2011. The New Zealand Film Archive Ngā Kaitiaki O Ngā Taonga Whitiāhua.

McIntosh, William, and Brandon Schmeichel. 2004. "Collectors and Collecting: A Social Psychological Perspective.” Leisure Sciences 26: 85-97. 
McLeod, Julie, and Rachel Thomson. 2009. “Revisiting.” In Researching Social Change, edited by Julie McLeod and Rachel Thomson. London: SAGE Publications Ltd. Accessed July 21, 2011. doi:10.4135/9780857029010

Merriman, Nick. 1989. "Museum Visiting as a Cultural Phenomenon.” In The New Museology, edited by Peter Vergo, 149-171. London: Reaktion Books.

Merriman, Nick. 1991. Beyond the Glass Case: The Past, Heritage and the Public in Britain. London: Leicester University Press.

Meyer, Morgan. 2008. "On the boundaries and partial connections between amateurs and professionals." Museum and Society 6(1): 38-53.

Miller, Robert L., and John D. Brewer. 2003a. "Qualitative Research.” In The A-Z of Social Research, edited by Robert L. Miller and John D. Brewer. London: SAGE Publications, Ltd. Accessed July 17, 2011. http://srmodev.ifactory.com/view/the-a-z-of-social-research/n83.xml

Miller, Robert L., and John D. Brewer. 2003b. "Sampling, Snowball: Accessing Hidden and Hard-To-Reach Populations.” In The A-Z of Social Research, edited by Robert L. Miller and John D. Brewer. London: SAGE Publications, Ltd. Accessed July 17, 2011. http://srmo-dev.ifactory.com/view/the-a-z-ofsocial-research/n94.xml

Molyneaux, Ian. 2010. “Caring for New Lynn's crown jewels.” Te Ara Journal of Museums Aotearoa 33(1\&2):35-37. Accessed March 10, 2012. http://www.museums-aotearoa.org.nz/Site/publications/Te_Ara_Online/Author/I-M/M/Molyneux_Ian/Caring_for_New_Lynns_crown_jewels . $\operatorname{aspx}$

Moore, Kevin. 1997. Museums and Popular Culture Contemporary Issues in Museum Culture. London: Cassell. 
Morrison, Rebecca Lynne. 2010. "Bringing the Collection to Life: A Study in Object Relations." PhD dissertation, University of Alberta. Accessed September 22, 2010. http://repository.library.ualberta.ca/ dspace/handle/10048/1124

Moulin, Raymonde. 1987. The French Art Market: A Sociological View. Translated by Arthur Goldhammer. New Brunswick, New Jersey: Rutgers University Press.

Museums Aotearoa Te Tari o Ngā Whare Taonga o te Motu. 2003. "Code of Ethics: For Governing Bodies of Museums and Museum Staff." Accessed February 7, 2012. http://www.museums-aotearoa.org.nz/Site/publications/COE.aspx

Museums Aotearoa Te Tari o Ngā Whare Taonga o te Motu. 2005. "A Strategy for the Museum Sector in New Zealand." Wellington: Museums Aotearoa Te Tari O Ngā Whare Taonga O Te Motu, The Museums of New Zealand.

Museum of New Zealand Te Papa Tongarewa. 2001. "Exhibitions at Your Place”. He Rauemi Resource Guide 10. Wellington: Museum of New Zealand Te Papa Tongarewa. Accessed January 07, 2012. http://www.tepapa.govt.nz/sitecollectiondocuments/tepapa/nationalservices/pd fs/resourceguides/exhibitions/exhibitions.pdf

Museum of New Zealand Te Papa Tongarewa. 2003. "Developing Your Collections Acquisition and Deaccession Policies." He Rauemi Resource Guide 16. Wellington: Museum of New Zealand Te Papa Tongarewa. Accessed January 07, 2012. http://www.tepapa.govt.nz/SiteCollectionDocuments/TePapa/NationalServices /pdfs/ResourceGuides/Governance/DevelopingCollection.pdf 
Museum of New Zealand Te Papa Tongarewa. 2007. "New Zealand Museums

Standards Scheme Ngā Kaupapa Whaimana a Ngā Whare Taonga o

Aotearoa." Wellington: Museum of New Zealand Te Papa Tongarewa.

Accessed January 24, 2012.

http://www.tepapa.govt.nz/SiteCollectionDocuments/NationalServices/HowW

eHelp/Introduction_standards\%20scheme\%20Dec2007.pdf

Museum of New Zealand Te Papa Tongarewa 2012. "National Services Te Paerangi:

Who We Are.” Accessed January 14, 2012.

http://www.tepapa.govt.nz/nationalservices/whoweare/Pages/Whoweare.aspx

National Library of New Zealand Te Puna Mātauranga o Aotearoa. 2005. “Oral History Recording Agreement Form.” Accessed September 23, 2010. http://www.natlib.govt.nz/catalogues/library-documents/oral-history-recordingagreement-form

National Oral History Association of New Zealand Te Kete Kōrero-a-Waha o Te Motu. 2001. "Code of Ethical and Technical Practice.” Last modified March 12. Accessed July 24, 2011. http://www.oralhistory.org.nz/code.htm

National Services Te Paerangi. 2010. "Search NZ Museums." Accessed September 01, 2010. http://www.nzmuseums.co.nz/

New Zealand Tourism Guide. 2010. "Museums.” Accessed September 02, 2010. http://www.tourism.net.nz/attractions-and-activities/museums-and-artgalleries/region.html

Patton, Michael Q. 1990. “Qualitative interviewing.” In Qualitative Evaluation and Research Methods, 277-359. Newbury Park, California: Sage Publications.

Patton, Michael Q.1999. “Enhancing the Credibility and Quality of Qualitative Analysis.” Health Services Research 34 (5). Accessed May 05, 2011. http://www.ncbi.nlm.nih.gov/pmc/articles/PMC1089059/pdf/hsresearch000220112.pdf 
Pearce, Susan M. 1992. Museums, Objects and Collections: A Cultural Study. Great Britain; United States: Leicester University Press; Smithsonian Institution Press.

Pearce, Susan M. 1995. “Collecting as Medium and Message.” In Museum, Media, Message, edited by Eileen Hooper-Greenhill, 15-23. London; New York: Routledge.

Pearce, Susan M. 1998. Collecting in Contemporary Practice. London: Sage Publications.

Pearce, Susan M. 2004. "Collections and Collecting." In Museums and the Future of Collecting, Second Edition, edited by Simon J. Knell, 47-51. Aldershot, Hampshire, Great Britain; Burlington, Vermont: Ashgate.

Pink, Sarah. 2004. "Performance, Self-Representation and Narrative: Interviewing with Video." In Seeing is Believing? Approaches to Visual Research, edited by Christopher Pole, 61-77. Amsterdam; San Diego; Langford; London: Elsevier Ltd.

Prior, Nick. 2002. Museums and Modernity: Art Galleries and the Making of Modern Culture. Oxford; New York: Berg.

Ravelli, Louise. 1996. "Making Language Accessible: Successful Text Writing for Museum Visitors.” Linguistics and Education 8:367-387.

Real Art Roadshow. 2012. "Photo Gallery.” Accessed April 02, 2012. http://www.realartroadshow.co.nz/rar_travelling-gallery.html

Reid, Alison. 2011. Interview by author. Digital video recording. Auckland, New Zealand, October 17, 2011. The New Zealand Film Archive Ngā Kaitiaki O Ngā Taonga Whitiāhua. 
Richins, Marsha L. 1994. "Valuing Things: The Public and Private Meanings of Possessions." Journal of Consumer Research Inc 21:504-521.

Rosenstein, Barbara, and Beer Sheva Israel. 2002. "Video Use in Social Science Research and Program Evaluation." International Journal of Qualitative Methods 1 (3): 22-43.

Russell, Roslyn, and Kylie Winkworth. 2009. Significance 2.0 - A Guide to Assessing the Significance of Collections. Collections Council of Australia Ltd. Accessed February 29, 2012. http://significance.collectionscouncil.com.au/pdf/bw/bSignificance20.pdf

Saisselin, Remy Gilbert. 1984. Bricobracomania: The Bourgeois and the Bibelots. New Brunswick, New Jersey: Rutgers University Press.

Sax, Joseph L. 1999. Playing Darts With a Rembrandt: Public and Private Rights in Cultural Treasures. Ann Arbor: University of Michigan Press.

Searle, Chloe Chantal. 2010. "Collecting for New Zealand: Examining What the Museum of New Zealand Te Papa Tongarewa Should Collect.” Master's thesis, Victoria University of Wellington, Wellington.

Shelton, Anthony. 2001. "Introduction: The Return of the Subject.” In Collectors: Expressions of Self and Other, edited by Anthony Shelton, 11-22. Horniman Museums and Gardens, London, The Museum Antropológico da Universidade de Combria. Singapore: Contributions in Critical Museology and Material Culture.

Shuker, Roy. 2004. "Beyond the 'High Fidelity' Stereotype: Defining the (Contemporary) Record Collector.” Popular Music 23 (3): 311-330.

Smith, Peter. 2012. Email to author April 12, 2012. 
Smith, Peter. 2011. Interview by author. Digital video recording. Auckland, New Zealand, October 14, 2011. The New Zealand Film Archive Ngā Kaitiaki O Ngā Taonga Whitiāhua.

Stebbins, Robert A. 1977. "The Amateur: Two Sociological Definitions.” The Pacific Sociological Review 20 (4):582-606.

Stebbins, Robert A. 1992. Amateurs, Professionals, and Serious Leisure. Montreal; Kingston; London; Buffalo: McGill-Queen's University Press.

Stebbins, Robert A. 2001. "Serious Leisure.” Society May/June: 53-57.

Stebbins, Robert A. 2002. The Organizational Basis of Leisure Participation: A Motivational Exploration. State College, Pennsylvania: Venture Publishing.

Stebbins, Robert A. 2007. Serious Leisure: A Perspective For Our Time. New Brunswick, New Jersey: Transaction Publishers.

Stebbins, Robert A. 2010. “Addiction to Leisure Activities: Is It Possible?” LSA Newsletter 86: 19-22. Accessed April 02, 2012. http://www.seriousleisure.net/uploads/8/3/3/8/8338986/reflections_24.pdf

Stig Sørenson, Marie Louise, 2009. "Between the Lines and in the Margins: Interviewing People About Attitudes to Heritage and Identity." In Heritage Studies: Methods and Approaches, edited by Marie Louise Stig Sørenson and John Carmen, 164-177. London; New York: Routledge.

Teddlie, Charles, and Fen Yu. 2007. "Mixed Methods Sampling: A Typology With Examples". Journal of Mixed Methods Research 1 (1): 77-100. doi: $10.1177 / 2345678906292430$

Victoria University of Wellington Research Policy Group. 2003. "Ethics Approval Human Ethics Policy." Accessed April 4, 2010. http://www.victoria.ac.nz/postgradlife/pages/pages_current_pg/ethics.html 
Warde, Alan. 2004. "Practice and Field: Revising Bourdieusian Concepts."

Discussion Paper 65, Centre for Research on Innovation and Competition, The University of Manchester. Accessed February 17, 2012. www.cric.ac.uk/cric/Pdfs/DP65.pdf

Weil, Stephen E. 2002. Making Museums Matter. Washington; London: Smithsonian Institution Press.

Wilkinson, T.M. 2001. “The Core Ideas of Research Ethics.” In Research Ethics in Aotearoa New Zealand: Concepts, Practice, Critique, edited by Martin Tolich, 13-24. Auckland: Longman an imprint of Pearson Education New Zealand Limited.

Yaya, Isabel. 2008. "Wonders of America: The Curiosity Cabinet as a Site of Representation and Knowledge." Journal of the History of Collections 20 (2): 173-188. 


\section{Appendix A: Information sheet}

Title of project: Private tastes and public desires: Exploring the perspectives and practices of private collectors who make their collections publicly accessible

Researcher: Kiri Griffin, Museum \& Heritage Studies Programme, School of Art History, Classics and Religious Studies, Victoria University of Wellington.

I am a Masters student in Museum Studies at Victoria University of Wellington undertaking a research project leading to a thesis. The project I am undertaking is examining private collectors who make their collections publicly accessible. These collectors make a significant contribution to the preservation and promotion of access to heritage materials and I believe their perspective is worthy of better understanding by scholars, heritage sector professionals and members of the public.

Participation in this research is entirely voluntary. It is the participant's choice whether they wish to partake or not. Participants may change their mind later and stop contributing even if they agreed earlier.

Participants who agree to be involved in this study will be asked to take part in an audiovisual interview. The focus of each interview will be the collecting activities of the private collector, with particular emphasis on how they conceive of the activity of sharing their collections publicly. Participants do not have to answer every question. They do not have to provide any reason for not responding to any question, or for refusing to take part in the interview

It is envisaged that the interview will take an hour-and-a-half to complete, with interviews being conducted at the location of the private collector's collection. If the participant agrees I would also like to capture audiovisual footage of the participant with their collection in situ. The interview will be transcribed in full. Transcripts will be sent to individual research participants prior to analysis so they can make any amendments or retractions they wish. A viewing copy of footage captured can also be supplied to the participant at their request. Participants will be asked to provide any feedback within a three-week period from the provision of the transcripts and can 
formally withdraw from the research anytime up until the $10^{\text {th }}$ December 2011.

Responses collected will form the basis of my thesis. The thesis will be submitted for marking to the Museum \& Heritage Studies programme and deposited in the Victoria University of Wellington Library. If the participant agrees, upon the conclusion of this study the audiovisual footage and transcripts of the footage will be deposited at The New Zealand Film Archive -repository acceptance permitting - with staff at the New Zealand Film Archive facilitating public access to the footage and transcripts. The purpose of archiving this material is to enhance the record of social history, documenting the thoughts and activities of private collectors who make their collections publicly accessible in New Zealand.

If participants have any questions or would like to receive further information about the project, please email me at [contact details removed], or phone me on [contact details removed]. Participants may also contact my supervisor, Dr Lee Davidson [contact details removed].

Signed:

Kiri Griffin 


\section{Appendix B: Consent form}

Title of project: Private tastes and public desires: Exploring the perspectives and practices of private collectors who make their collections publicly accessible

I have been given and have understood an explanation of this research project. I have had an opportunity to ask questions and have them answered to my satisfaction. I understand that I may withdraw myself (or any information I have provided) from this project before the $10^{\text {th }}$ of December 2011 without having to give reasons.

I understand that any information I provide will be kept confidential to the researcher and the supervisor during this project. I understand that I will have an opportunity to check the transcripts of footage captured before publication. I understand that the footage and transcripts will be deposited at The New Zealand Film Archive at the end of the project unless I indicate that I would like these materials returned to me.

I consent to information or opinions that I have given being attributed to me in Kiri Griffin's thesis, which I understand is to be deposited at Victoria University of Wellington Library. I also consent to information or opinions that I have given being attributed to me in any reports (academic or professional) on this research.

I agree to take part in this research.

I would like to receive a summary of the results of this research when it is completed.

Yes/No

If Yes, please provide an email address:

Name of participant (please print clearly):

Signed:

Date: 


\section{Appendix C: Oral history recording agreement form}

This Agreement Form is approved by the National Oral History Association of New Zealand and was accessed from the following National Library of New Zealand URL: http://www.natlib.govt.nz/services/catalogues/library-documents/oral-historyrecording-agreement-form

NAME OF PROJECT: Private tastes and public desires: Exploring the perspectives and practices of private collectors who make their collections publicly accessible

FULL NAME OF PERSON INTERVIEWED:

DATE OF INTERVIEW:

COMMISSIONING ORGANISATION/PERSON: Kiri Griffin

INTERVIEWER:

COPYRIGHT HOLDER:

1. PLACEMENT: I, the person interviewed, agree that the recording of my interview and accompanying material, prepared for archival purposes, will be held at The New Zealand Film Archive.

2. ACCESS: I agree that the recording of my interview and accompanying material may be made available for research, at the above location or at a location approved by the commissioning organisation/person, subject to any restrictions in Section 4.

3. PUBLICATION: I agree that the recording of my interview and accompanying material, may be quoted or shown in full or in part in published work, broadcast, or used in public performances, subject to any restrictions in Section 4. 


\section{RESTRICTED RECORDINGS AND ACCOMPANYING MATERIAL:}

I require that there be no access to $\quad \square$ (cross where appropriate)

I require that there be no publication of

this recording and accompanying material without my prior written permission

NOTES:

REVIEW/RELEASE DATE:

5. PRIVACY ACT: I understand that this Agreement Form does not affect my rights and responsibilities under the Privacy Act 1993.

6. COMMENTS:

PERSON INTERVIEWED:

Date:

INTERVIEWER:

Date:

FOR COMMISSIONING

ORGANISATION:

Date:

NOTE: This Agreement Form may be amended only by the person interviewed, or by the commissioning organisation/person with the authority of the person interviewed. Any amendment must be registered with the commissioning organisation/person. 


\section{Appendix D: National Oral History Association of New Zealand Te Kete Kōrero-a-Waha o Te Motu Code of ethical and technical practice}

This Code exists to promote ethical, professional and technical standards in the collection, preservation and use of sound and video oral history material.

\section{Interviewers have the following responsibilities}

- To inform the person interviewed of the purposes and procedures of oral history in general and of the particular project in which they are involved

- To inform the person interviewed of issues such as copyright, ownership, privacy legislation, and how the material and accompanying material may be used

- To develop sufficient skills and knowledge in interviewing and equipment operation, e.g. through reading and training, to ensure a result of the highest possible standard

- To use equipment that will produce recordings of the highest possible standard

- To encourage informative dialogue based on thorough research

- To conduct interviews with integrity

- To conduct interviews with an awareness of cultural or individual sensibilities

- To treat every interview as a confidential conversation, the contents of which are available only as determined by written or recorded agreement with the person interviewed

- To place each recording and all accompanying material in an archive to be available for research, subject to any conditions placed on it by the person interviewed - to inform the person interviewed of where the material will be held

- To respect all agreements made with the person interviewed 


\section{Appendix E: Interview Guide}

This guide was informed by questions listed in The Smithsonian Folklife and Oral

History Interviewing Guide (Hunt 2003) and Michael Q. Patton's (1990) chapter

'Qualitative Interviewing' which details types of qualitative questions.

\section{Background/Demographic questions}

What is your name?

Where and when were you born?

Where did you grow up?

Where have you lived?

What jobs have you had?

What do you do for a living now?

\section{Experience/Behaviour questions}

What got you interested in collecting?

How did you first start collecting?

How did you learn your skills? When?

What was the learning process like? What is the most challenging or difficult aspect

of collecting to learn? Why?

Describe the steps of the process from start to finish. What's involved?

What tools are involved? How and when are they used?

Where do you get your materials/supplies?

Have they changed over time? How? Why?

In what context do you share your collections publicly? For whom? When?

What motivated you to share your collection publicly?

How regularly would you visit publicly funded museums, art galleries, cultural heritage institutions? Which ones? What are your experiences like?

\section{Knowledge questions}

What special knowledge, skills, and abilities are needed?

What criteria do you use to evaluate your collections? 


\section{Opinion/Values questions}

How do you distinguish your collection from other collections?

How do you judge other collectors and cultural institutions that collect?

What makes someone respected as a collector?

What do you value most about what you do? Why?

How does the sharing of your collections with members of the public relate to the values you hold?

What do you think is the future of your collection? What are its challenges and opportunities? 